\title{
Low-Flow Characteristics of Streams in the Trempealeau-Black River Basin, Wisconsin
}

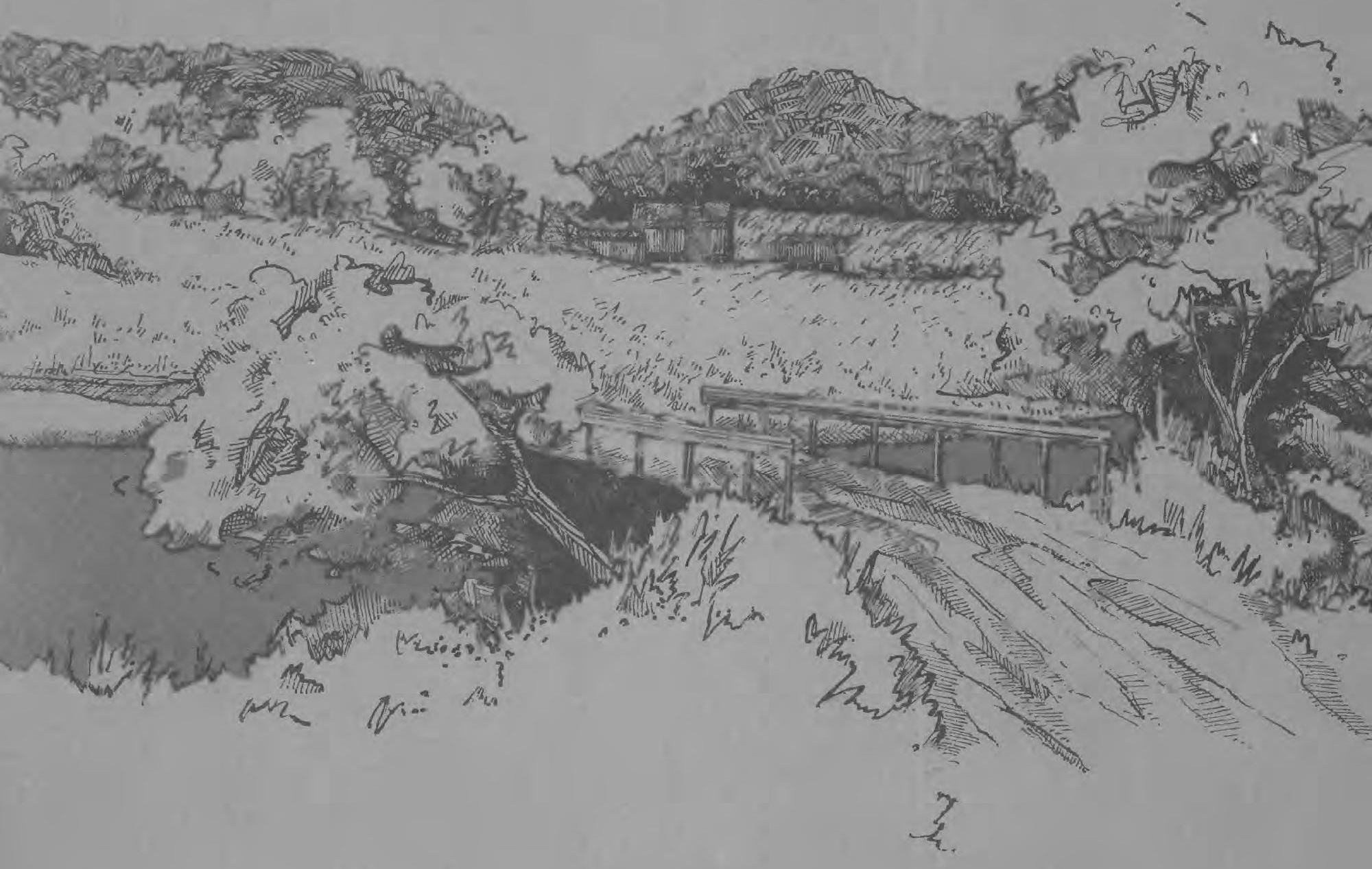

PREPARED BY

UNITED STATES DEPARTMENT OF THE INTERIOR GEOLOGICAL SURVEY

IN COOPERATION WITH

WISCONSIN DEPARTMENT OF NATURAL RESOURCES 


\title{
Low-Flow Characteristics of Streams in the Trempealeau-Black River Basin, Wisconsin
}

\author{
B. K. HOLMSTROM
}

U. S. GEOLOGICAL SURVEY

Water Resources Investigations

Open-File Report 79-9

Prepared in cooperation with the

Wisconsin Department of Natural Resources

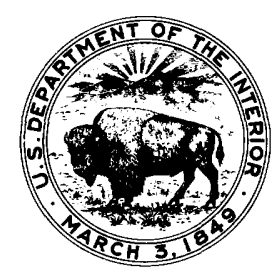

FEBRUARY 1979 


\title{
UNITED STATES DEPARTMENT OF THE INTERIOR
}

\author{
CECIL D. ANDRUS, SECRETARY
}

\section{GEOLOGICAL SURVEY}

\author{
H. William Menard, Director
}

For additional information write to:

U. S. Geological Survey

1815 University Avenue

Madison, Wisconsin 53706 


\section{CONTENTS}

$\underline{\text { Page }}$

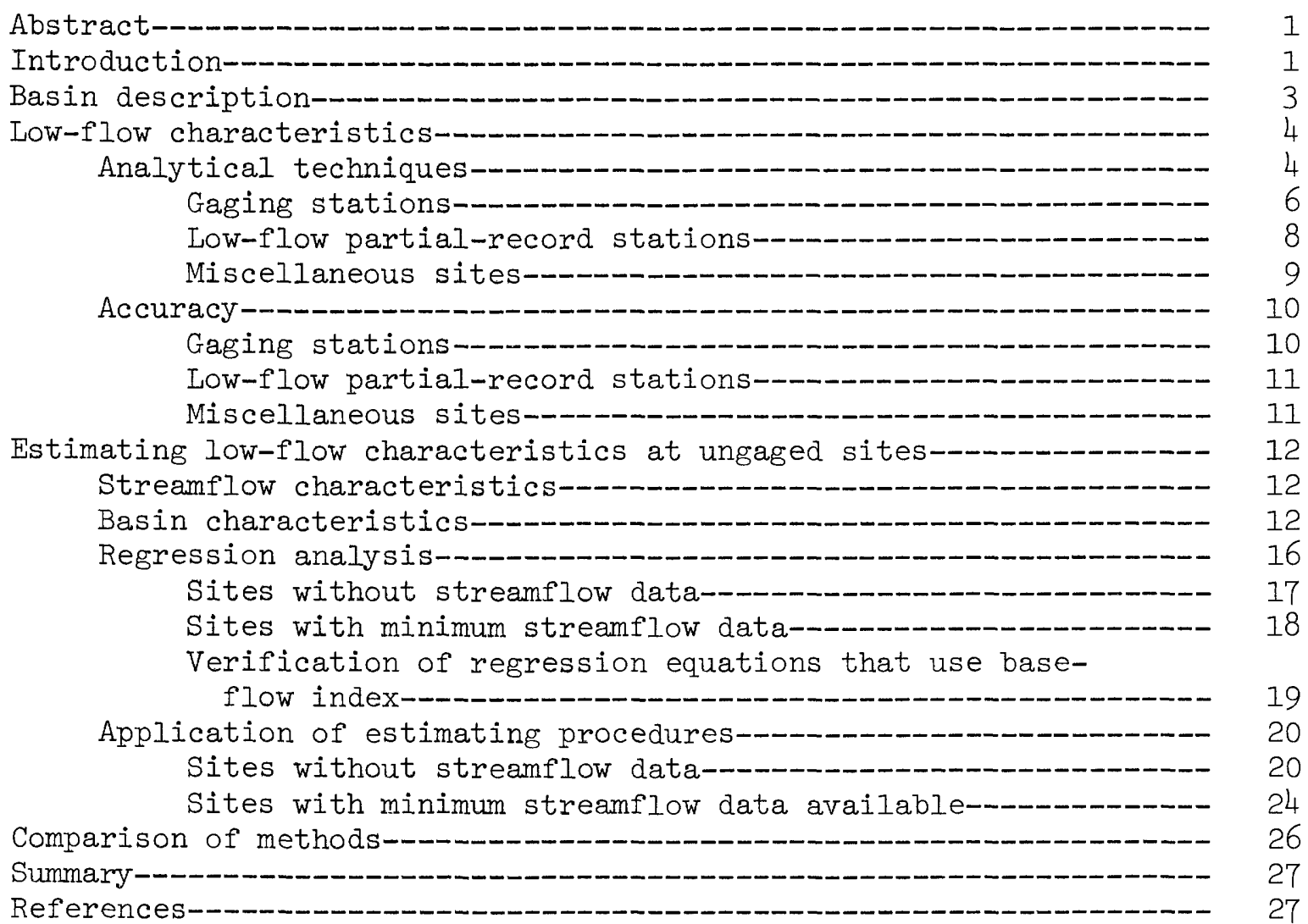

\section{ILLUSTRATIONS}

Plate 1. Glacial geology and drift thickness in the TrempealeauBlack River basin, Wisconsin

2. Locations of gaging stations, low-flow partial-record stations, and miscellaneous sites in the TrempealeauBlack River basin, Wisconsin

3. Permeability rates of soils in the Trempealeau-Black River basin, Wisconsin

4. Base-flow index values for selected stations and sites in the Trempealeau-Black River basin, Wisconsin

$\underline{\text { Page }}$

Figure 1. Map showing location of the Trempealeau-Black River basin--_-_-_-_-_-_-_-_-_-_-_-_-_-_-_-_-_-_-_-

2. Hydrograph showing daily discharge of Trempealeau River for 1965 climatic year showing annual low-flow periods for various number of days-_-_._-_._- 
3. Low-flow frequency curves of the annual minimum mean discharge for the indicated number of consecutive days at Trempealeau River-_._-_._- 6

4. Flow-duration curve showing the percentage of time a given discharge was exceeded for Trempealeau River----- 7

5. Graph showing method of estimating $Q_{7,2}$ and $Q_{7,10}$ at low-flow partial-record stations-_, 2

6. Graph showing method of estimating $Q_{7,2}$ and $Q_{7,10}$ at miscellaneous sites-_-_-_-_-__-_I, 2

7. Map showing average annual precipitation--_-_-_-_-_-_-- 14

8. Map showing average annual snowfall-_-_-_-_-_-_-_-_- 15

\section{TAB LES}

Page

Table 1. Low-flow characteristics for sites in the TrempealeauBlack River basin-_-_-_-_-_-_-

2. Drainage-basin characteristics for low-flow partialrecord stations and selected gaging stations in the

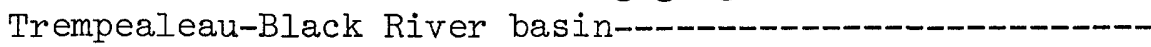

3. Comparison of methods available to estimate low-flow characteristics in the "Driftless Area" of the Trempealeau-Black' River basin-_-_-_-_-_-_-_-_-_-_

4. Comparison of methods available to estimate low-flow characteristics in the glaciated area of the Trempealeau-Black River basin-_-_-_-_-_-_-_-_-_-_ 


\title{
Low-Flow Characteristics of Streams in the Trempealeau-Black River Basin, Wisconsin
}

\author{
B. K. HOLMSTROM
}

\begin{abstract}
Low-flow characteristics of streams in the Trempealeau-Black River basin are presented. Included are estimates of low-flow frequency and flow duration at 9 gaging stations, and low-flow frequency characteristics at 20 low-flow partial-record stations and 119 miscellaneous sites.

Ten equations are provided to estimate low-flow characteristics at ungaged sites and at sites where one base-flow discharge measurement is available. The low-flow characteristics determined were the annual minimum 7 -day mean flow below which the flow will fall on an average of once in 2 years $\left(Q_{7}, 2\right)$ and once in 10 years $(27,10)$. The equations were determined from multiple-regression analyses that related the low-flow characteristics at gaging stations and low-flow partial-record stations to basin characteristics. Drainage area, soil-infiltration rate, transmissivity, precipitation, snowfall, and base-flow index were the most significant parameters for these analyses.
\end{abstract}

\section{INTRODUCTION}

The purpose of this report is to describe low-flow characteristics of streams in the Trempealeau-Black River basin where streamflow data have been collected and to present equations useful for estimating low-flow characteristics at ungaged sites.

This study was done in cooperation with the Wisconsin Department of Natural Resources. This report is part of a series of 12 planned reports to describe low-flow characteristics of the major basins in Wisconsin (fig. 1). 
The report includes: estimates of the magnitude and frequency of recurrence of low flow for various sites where streamflow information has been collected, low-flow discharge measurements that have been obtained at numerous sites throughout the basin, and a method to estimate low-flow characteristics at ungaged sites.

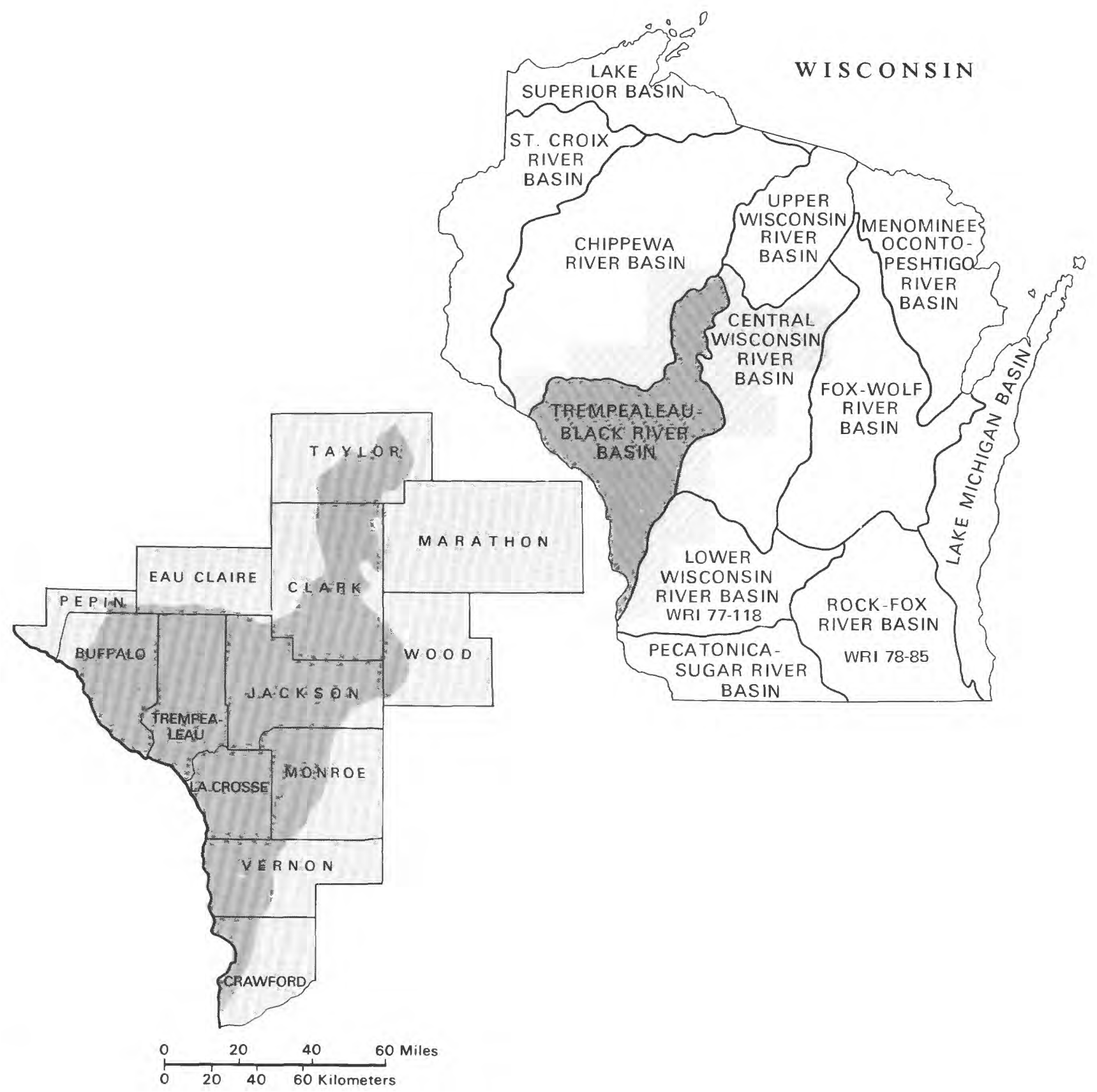

Figure 1. Location of the Trempealeau-Black River basin. 
In recent years, a great demand has been placed on water resources in Wisconsin by increased multiple uses such as: maintenance of fish and wildlife habitat, irrigation of crops, dilution and assimilation of wastes, production of hydroelectric power, construction of impoundments for realestate developments, and maintenance of adequate flow for canoeing. This increased demand requires an accurate determination of water resources during low-flow periods to ensure proper consideration of all users.

Low-flow frequency analyses and flow-duration analyses are presented for all current and discontinued gaging stations in the Trempealeau-Black River basin. These analyses have been completed for 9 gaging stations through water year 1976. Low-flow frequency data are included in the report for 20 low-flow partial-record stations and for 119 miscellaneous sites.

Previous reports by Gebert and Holmstrom (1974, p. 9, 12-14, 41, 7677), Gebert (1971), and Young and Borman (1973, sheet 2) contain preliminary information on low-flow characteristics of this basin.

For the convenience of readers who may want to use metric units, the data may be converted by using the following factors:

\section{Multiply}

mile $(\mathrm{mi})$

foot ( $f t$ )

square mile $\left(\mathrm{mi}^{2}\right)$

cubic foot per second

$(\mathrm{ft} 3 / \mathrm{s})$

foot per mile ( $\mathrm{ft} / \mathrm{mi}$ )

inch (in.)

cubic foot per second per

square mile $\left\{(\mathrm{ft} 3 / \mathrm{s}) / \mathrm{mi}^{2}\right\}$

gallon per day (gal/d)

gallon per day per square

foot $\left\{(\mathrm{gal} / \alpha) / \mathrm{ft}^{2}\right\}$
By

1.609

.3048

2.59

.02832

.1894

2.54

.01094

.003786
$3.517 \times 10^{-4}$

\section{To obtain}

kilometer $(\mathrm{km})$

meter $(\mathrm{m})$

square kilometer $\left(\mathrm{km}^{2}\right)$

cubic meter per second

$$
\left(\mathrm{m}^{3} / \mathrm{s}\right)
$$

meter per kilometer $(\mathrm{m} / \mathrm{km})$ centimeter $(\mathrm{cm})$

cubic meter per second per square kilometer

$$
\left\{\left(\mathrm{m}^{3} / \mathrm{s}\right) / \mathrm{km}^{2}\right\}
$$

cubic meter per day $\left(\mathrm{m}^{3} / \mathrm{d}\right)$ cubic meter per day per square meter $\left\{\left(\mathrm{m}^{3} / d\right) / \mathrm{m}^{2}\right\}$

\section{BASIN DESCRIPTION}

The Trempealeau-Black River basin is in west-central Wisconsin. It includes the drainage area of streams tributary to the Mississippi River between the Chippewa River and the Wisconsin River. The basin has a drainage area of approximately $4,950 \mathrm{mi}^{2}, 8.8$ percent of the state.

The 1974 population of the Trempealeau-Black River basin was approximately 200,000. The largest cities are La Crosse, Sparta, and Prairie du Chien, with 1976 populations of 48,845, 6,608, and 5,673, respectively (Wisconsin Legislative Reference Bureau, 1977). 
The mean annual precipitation for the basin is 31.6 in., 04 percent which occurs from May through September. Snowfall is 15 to 20 percent of the mean annual precipitation. The mean annual runoff is $8.3 \mathrm{in.,}$ and mean annual evapotranspiration is 23.3 in. (Young and Borman, 1973, sheet 1).

The stream valleys in the "Driftless Area" are narrow and V-shaped and contain unconsolidated alluvium. Approximately one-fourth of the basin was glaciated. The glacial drift consists mainly of till that covers the upper part of the Black River basin and unpitted outwash sand and gravel in the Black and Mississippi River valleys (Young and Borman, 1973, sheet 1) ( $\mathrm{pl}$. I).

Most streams have moderate slopes of 4 to $5 \mathrm{ft} / \mathrm{mi}$ in the lower reaches with steep gradients of 15 to $30 \mathrm{ft} / \mathrm{mi}$ in the headwaters. An exception is the Black River, which has a gradient of $2 \mathrm{ft} / \mathrm{mi}$ from Black River Falls to the mouth and $6 \mathrm{ft} / \mathrm{mi}$ upstream from Black River Falls (Young and Borman, 1973, sheet 1).

\section{LOW-FLOW CHARACTERISTICS}

Low flow generally refers to the low range of stream discharge. A probability of occurrence and a time period can be specified for a more precise definition. Low flow is usually ground-water runoff or base flow, although a 30-, 60-, or 90-day low flow could contain some direct or storm runoff.

A typical low-flow period is illustrated by the discharge hydrograph for Trempealeau River at Dodge gaging station (fig. 2). The annual 90-day low flow occurs from June 5 to September 2. Although this was the lowest flow for 90 consecutive days during the year, periods of direct runoff occurred on at least six occasions. Except for these rises in stream discharge, the remainder of streamflow for the period was predominantly base flow or ground-water runoff.

Low-flow characteristics at 187 sites are given in table 1 . Each site is identified by station number and station name. The site location, drainage area, type of site, and other pertinent data are included. Characteristics included for each site depend upon the type of site: gaging station, low-flow partial-record station, or miscellaneous site. The locations of the sites are shown on plate 2.

\section{ANALYTICAL TECHNIQUES}

Low-flow characteristics in table 1 were determined by three methods of analysis. These methods depended on the three basic types of data available: ( 1 ) continuous record of daily streamflows (continuous-record gaging stations); (2) 7 to 25 base-flow discharge measurements (low-flow partial-record stations); (3) 1 to 11 base-flow discharge measurements (miscellaneous sites). 


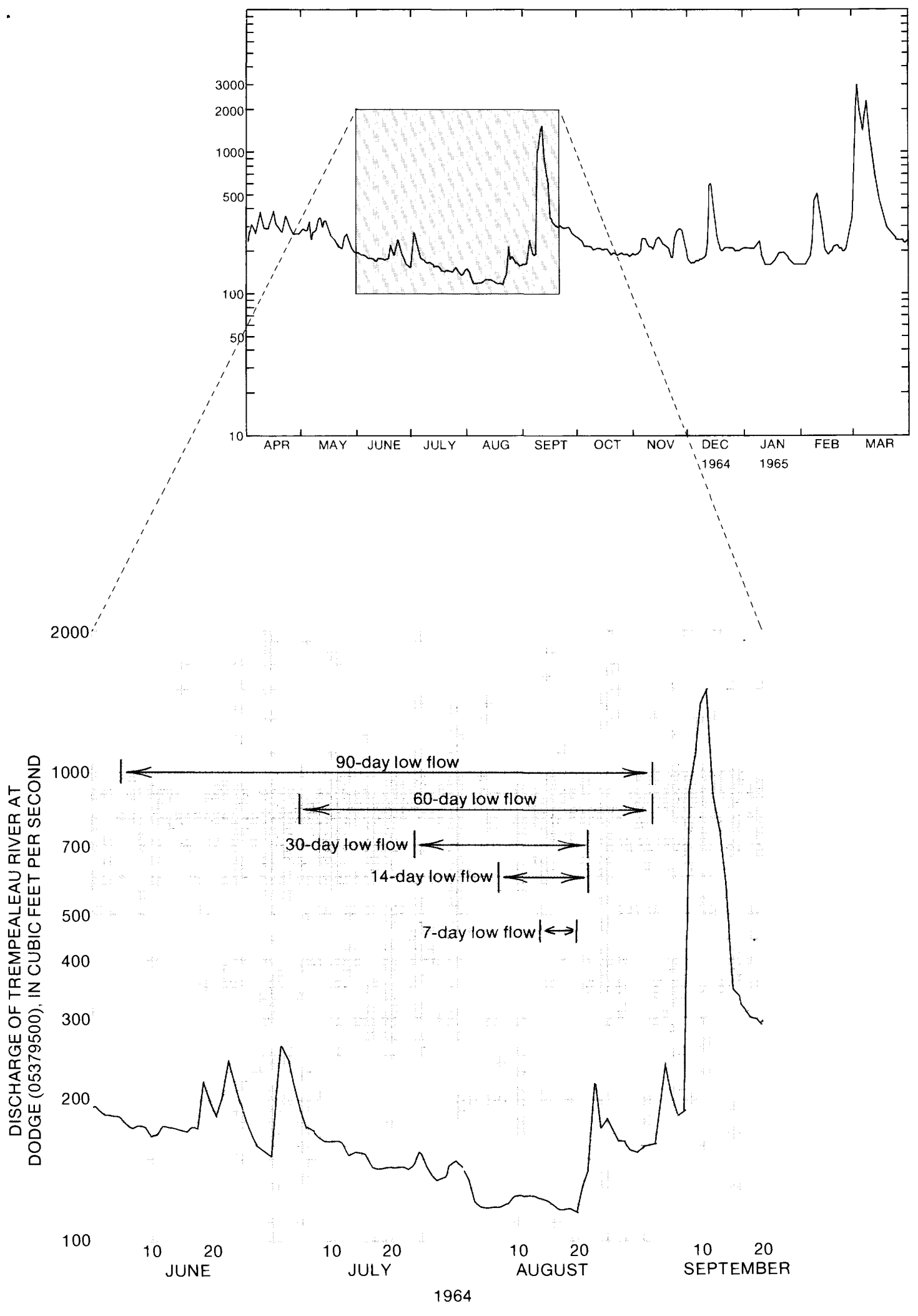

Figure 2. Daily discharge of Trempealeau River at Dodge for 1965 climatic year showing anmual low-flow periods for various number of days. 


\section{GAGING STATIONS}

Low-flow characteristics of a stream where systematic streamflow records have been collected can be determined by flow-duration analysis or frequency analysis. The two analyses serve different purposes. The flowduration curve indicates the percentage of time that a daily mean flow exceeds a given discharge, and the low-flow frequency curve indicates the probability that a 7-day, 14-day, 30-day, 60-day, or 90-day consecutive mean flow will be exceeded in any given year. The recommended and more generally used analysis for low-flow applications is the low-flow frequency analysis. In this basin the annual minimum 7-day mean flow below which the flow will fall on an average of once in 2 years $\left(Q_{7,2}\right)$ is approximately equal to 93 percent flow duration. The annual minimum 7-day mean flow below which the flow will fall on an average of once in 10 years $(27,10)$ is about equal to 99.6 percent flow duration.

Low-flow frequency and flow-duration analyses were completed for all continuous-record gaging stations where data are sufficient: 10 years of record for low-flow frequency analysis and flow-duration analysis. Lowflow frequency values given in table 1 show the magnitude and frequency of

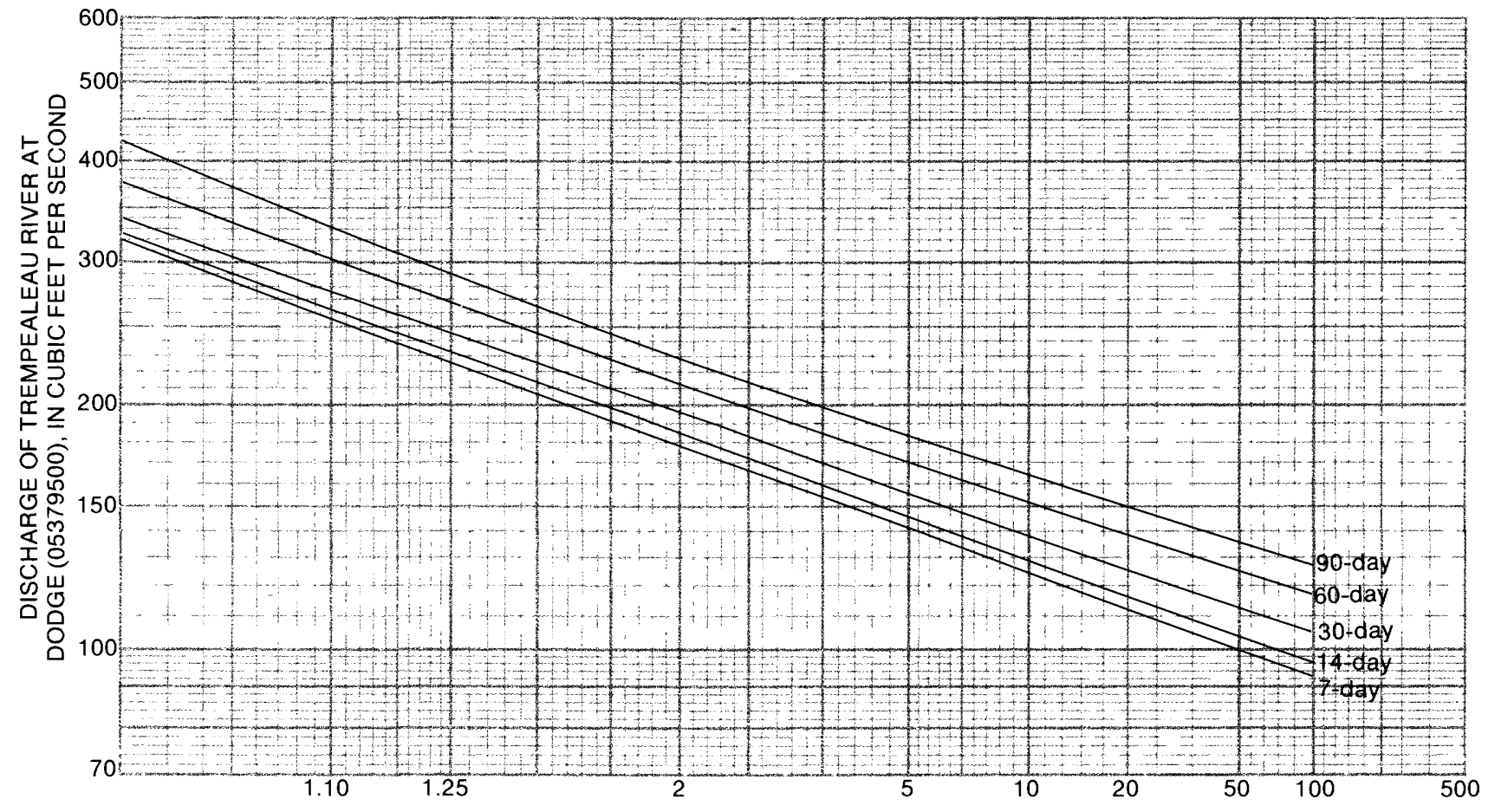

RECURRENCE INTERVAL, IN YEARS

Figure 3. Low-flow frequency curves of the annual minimum mean discharge for the indicated number of consecutive days at Trempealeau River at Dodge. 
annual low flows for $7,14,30,60$, and 90 consecutive days. Flow-duration values showing the percentage of time that specified discharges were exceeded also are shown in table 1 .

The low-flow frequency characteristics were determined from the daily discharge records using a log-Pearson Type III probability distribution or a plotting position analysis (Riggs, 1972, p. 1-8). If results of the two analyses were substantially different, the plotting position analysis was used. Figure 3 is an example of a low-flow frequency curve for the Trempealeau River at Dodge gaging station, and figure 4 is a flow-duration curve for the same site.

For gaging stations that have insufficient data for low-flow frequency analysis or flow duration, the low-flow characteristics were determined by a procedure similar to that outlined in the following section for low-flow partial-record stations.

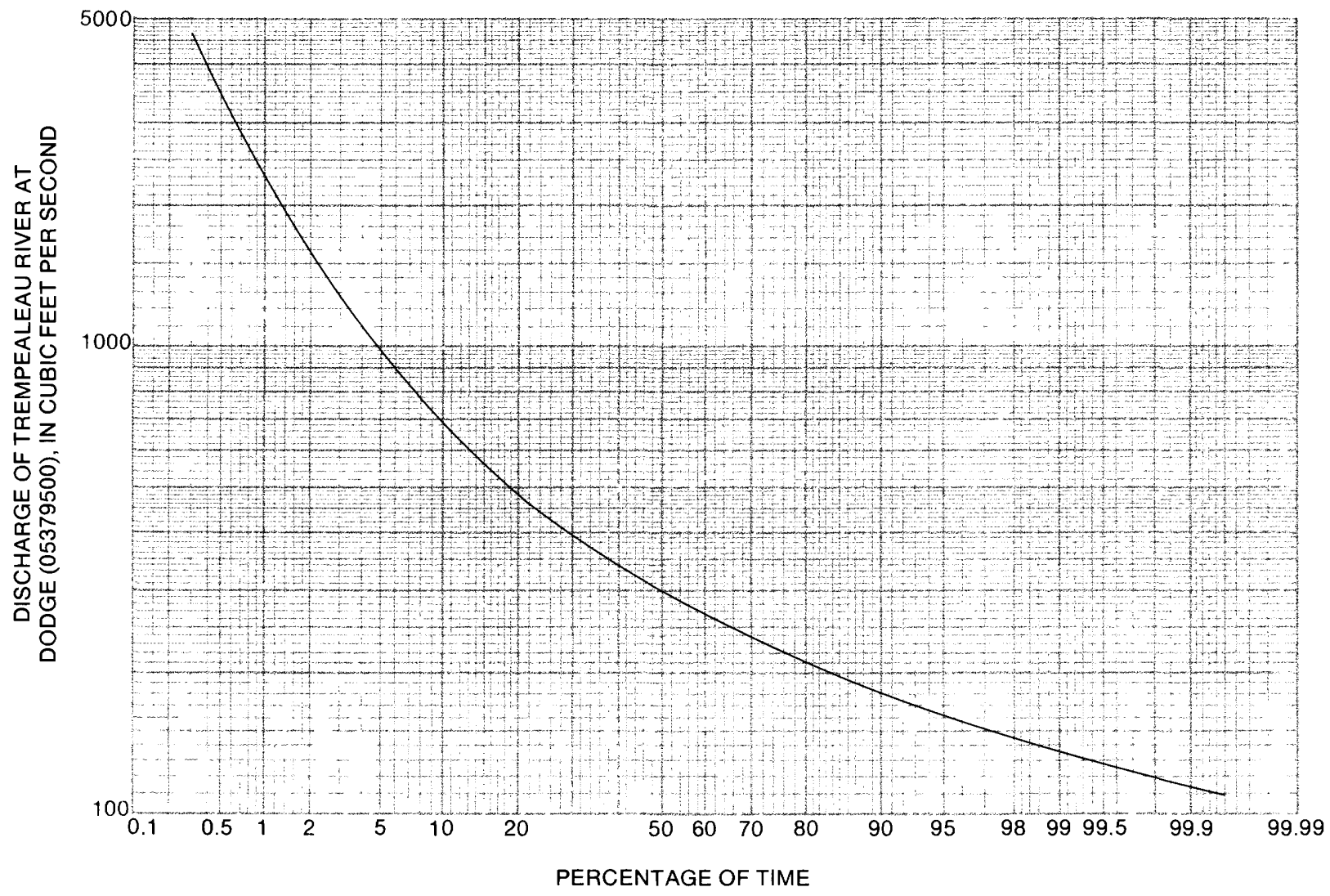

Figure 4. Flow-duration curve showing the percentage of time a given discharge was exceeded for Trempealeau River at Dodge. 
Low-flow characteristics determined for low-flow partial-record stations are the $Q_{7,2}$ and $Q_{7,10}$. Estimates of $Q_{7,2}$ and $Q_{7,10}$ are presented in table 1 for 20 low-flow partial-record stations. Characteristics were determined from a relation line established by correlating 7 to 25 baseflow discharge measurements at low-flow partial-record stations with concurrent discharges at continuous-record gaging stations in the area (Gebert, 1971). The $Q_{7,2}$ and $Q_{7,10}$ at the continuous-record gaging station then were transferred through the relation line to estimate 27,2 and $Q 7,10$ for the partialrecord station. Figure 5 is an example of this type of analysis for the low-flow partial-record station, Elk Creek at Elk Creek.

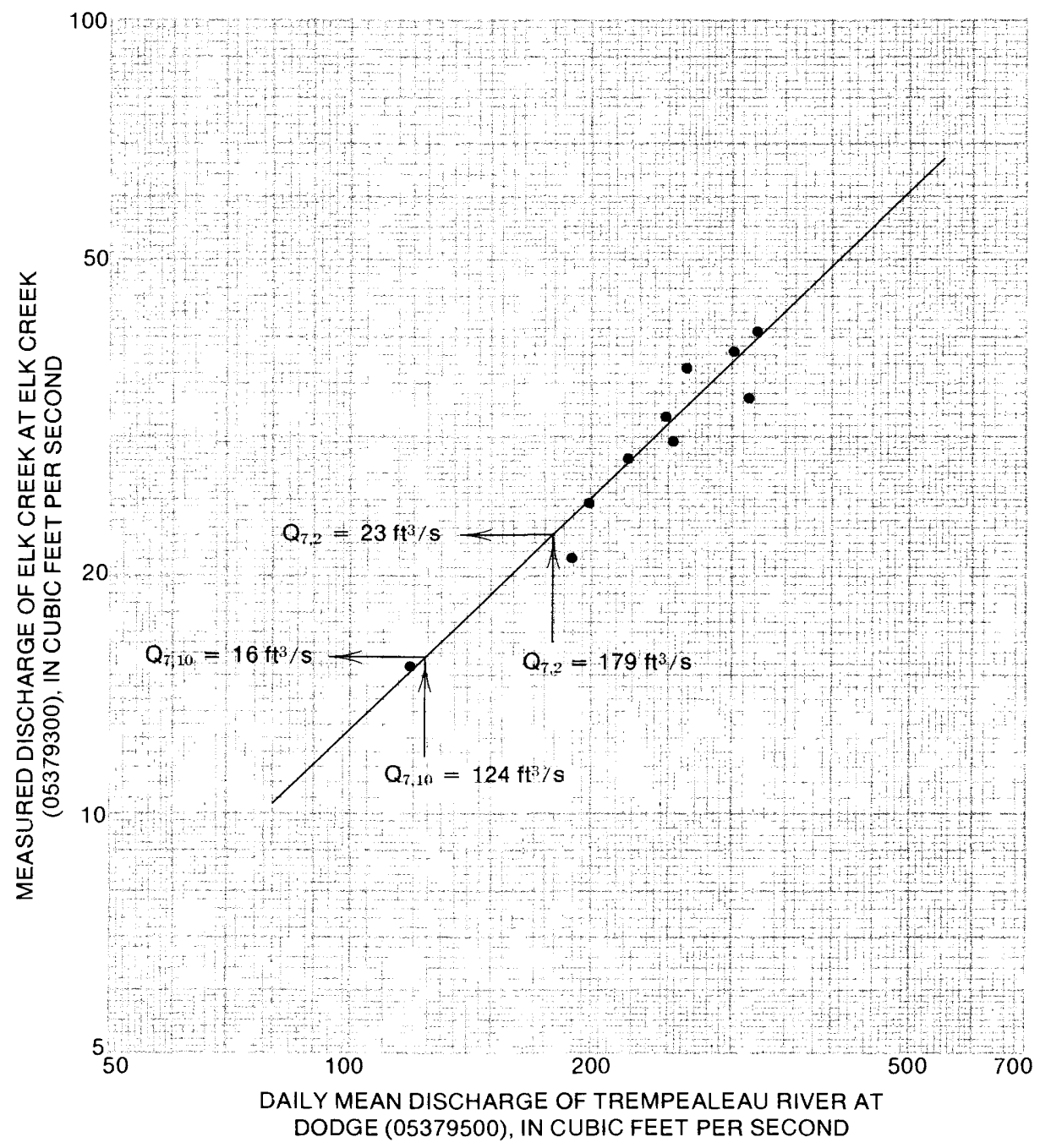

Figure 5. Method of estimating $Q_{7,2}$ and $Q_{7,10}$ at low-flow partialrecord stations. 


\section{MISCELLANEOUS SITES}

Base-flow measurements have been obtained at 158 miscellaneous sites in the Trempealeau-Black River basin as part of other water-resource investigations. Low-flow characteristics were estimated for 46 of these sites (table 1) where at least 3 base-flow discharge measurements were available and a well-defined relationship existed between the measured discharge and the concurrent daily mean discharge at a nearby gaging station. Estimates of 27,2 and $Q 7,10$ were made by the same type of analysis that was used for partial-record'stations (Gebert and Holmstrom, 1974, p. 3-4). Figure 6 illustrates this type of analysis for the miscellaneous site, Waumandee Creek near Waumandee. The slope of the relation line for miscellaneous

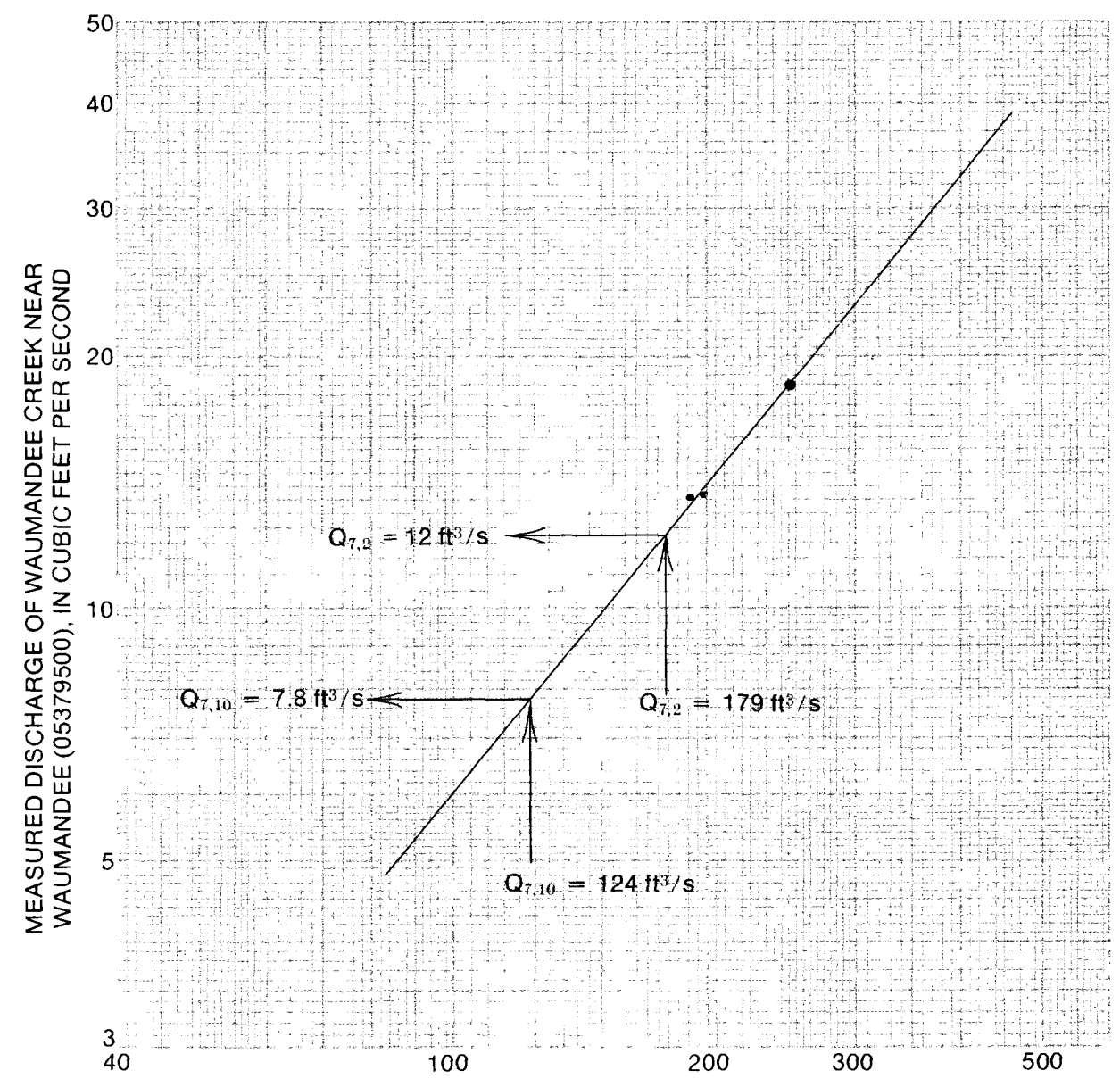

DAILY MEAN DISCHARGE OF TREMPEALEAU RIVER AT DODGE (05379500), IN CUBIC FEET PER SECOND

Figure 6. Method of estimating $Q_{7.2}$ and $Q_{7,10}$ at miscellaneous sites. 
sites was compared to established relation lines of nearby low-flow partialrecord stations and other miscellaneous sites for uniformity. Generally the relation line should have approximately the same slope if the factors that influence low flow are uniform for the area. If the relation line at the site being studied was defined by three discharge measurements that had significant scatter, the line was adjusted to agree more closely with the better established relation line at a low-flow partial-record station.

For 73 miscellaneous sites that had 1 or 2 discharge measurements or correlation analysis was inadequate, the low-flow characteristics were determined by use of regression equations. The regression equations used and discussion of their development is presented later in the report (p. 1220).

Low-flow characteristics were not estimated at 39 miscellaneous sites because less than 3 discharge measurements were available and the site had a drainage area greater than $150 \mathrm{mi}^{2}$ or regression equations provided estimates that were obviously poor when compared to existing data at nearby sites. Base-flow discharge measurements are listed for these sites.

\section{ACCURACY}

The low-flow characteristics listed in table 1 are estimates of flow expected in the future. Low-flow characteristics like other streamflow characteristics are only estimates, with their true value being difficult or impossible to determine. The estimates are based on data collected at each site and analyzed by several methods. Each estimate has an error associated with it, dependent on the amount and kind of data, and the analytical method. Two major sources of error are the time-sampling error in streamflow records and the error in the analytical method.

The expected degree of accuracy for the $0_{7,2}$ and $0_{7,10}$ estimates are presented in table 1 for selected sites. The accuracy is determined by the standard error of estimate for the 7-day, 2-year low flow $\left(\mathrm{SE}_{7,2}\right)$ and for the 7-day, 10-year low flow $\left(\mathrm{SE}_{7}, 10\right)$. The standard error of estimate is a range so that the values estimated by the method are within this range at 67 percent of the sites and within twice this range at about 95 percent of the sites.

The methods used to obtain the standard errors are not precise, and the standard errors presented in table 1 should be used as a relative guide to indicate a general level of confidence. In addition, there may be greater errors associated with accuracy estimates for low-flow estimates that approach $0 \mathrm{ft} 3 / \mathrm{s}$.

\section{GAGING STATIONS}

Accuracy of low-flow characteristics at gaging stations was determined according to Hardison and Moss (1972, p. 38). An average $\mathrm{SE}_{7,2}$ of 5 percent and $\mathrm{SE}_{7,10}$ of 8 percent was determined for the seven gaging stations in the Trempealeau-Black River basin that had longer than 10 years of streamflow record. 
A common length of record was used to compare the accuracy of low-flow characteristics determined from recorded discharge at gaging stations in the Trempealeau-Black River basin with that of gaging stations throughout the state. This analysis assumed that 10 years of record was available at each gaging station to determine the 07,10 discharge. An $\mathrm{SE}_{7,10}$ of 6 percent was determined for the five gaging stations in the "Driftless Area" of the Trempealeau-Black River basin and an $\mathrm{SE}_{7,10}$ of 62 percent was determined for the one gaging station in the glaciated area. An $\mathrm{SE}_{7}, 10$ of 16 percent was determined for gaging stations throughout the State. This indicates that low-flow characteristics can be determined with better-than-average accuracy in the "Driftless Area" and less-than-average accuracy in the glaciated area of the Trempealeau-Black River basin.

\section{LOW-FLOW PARTIAL-RECORD STATIONS}

The accuracy of low-flow characteristics at low-flow partial-record stations was determined by a method developed by Hardison and Moss (1972, p. 36-37). Using this method, an average $\mathrm{SE}_{7}, 10$ of 13 percent was found for 13 low-flow partial-record stations in the "Driftless Area" and an $\mathrm{SE}_{7,10}$ of 37 percent for 5 low-flow partial-record stations in the glaciated area of the Trempealeau-Black River basin. The accuracy analysis was not applicable for the two low-flow partial-record stations that had 27,10 's of zero. This compares to an average $\mathrm{SE}_{7,10}$ of 29 percent for 265 low-flow partial-record stations throughout the State.

\section{MISCELLANEOUS SITES}

The accuracy of low-flow characteristics at miscellaneous sites was determined as an average value for the entire basin by analyzing data collected at low-flow partial-record stations. Three random base-flow measurements were selected from the 7 to 25 measurements available at the 18 low-flow partial-record stations. Low-flow characteristics were determined from these three measurements using the same procedure used for miscellaneous sites. Then low-flow characteristics determined by this method were plotted against the low-flow characteristics based on 7 to 25 measurements. The SE between the two methods was determined from this plotted relationship. The overall SE includes the SE determined by the plotted relationship and the $\mathrm{SE}$ associated with the low-flow estimates based on 7 to 25 measurements. Assuming the two errors are independent the overall SE can be approximated by taking the square root of the sum of the squares of the two different SE's. For the Trempealeau-Black River basin this resulted in an $\mathrm{SE}_{7}, 10$ of 19 percent for the "Driftless Area" ( $\mathrm{pl} .1$ ) and an $\mathrm{SE}_{7,10}$ of 68 percent for the glaciated area (pI. 1), which are listed in table 1 as the basin averages. These values should be used cautiously for any particular site as the actual value for a subbasin could be significantly different from the mean for the basin. If the low-flow characteristics are based on more than three discharge measurements, the accuracy will probably be improved and should approach the accuracy at low-flow partial-record stations as additional measurements are obtained. 


\section{ESTIMATING LOW-FLOW CHARACTERISTICS AT UNGAGED SITES}

A method is required to transfer low-flow characteristics from gaged sites to ungaged sites because it is impossible to obtain actual streamflow data for all sites where the information is needed. The most practical transfer method relates low-flow characteristics to topographic, climatic, and aquifer characteristics of the drainage basin by multiple-regression analysis. Characteristics used in the multiple-regression analysis and the equations determined are discussed in the following paragraphs. The method is outlined in detail by Thomas and Benson (1970).

\section{STREAMFLOW CHARACTERISTICS}

Streamflow characteristics that were studied are the 07,2 and 07,10 that are widely used to describe low flow. The streamflow characteristics are the dependent variable in the multiple-regression analysis.

\section{BASIN CHARACTERISTICS}

Differences in streamflow for different locations and times are caused by differences in precipitation patterns and runoff characteristics. Climatic, topographic, and aquifer characteristics are quantified to explain the differences in low flow. These indices are the independent variables in the multiple-regression analysis.

Basin characteristics were selected for the analyses because of their known influence on the rainfall-runoff process. The following list of basin characteristics contains a brief discussion of their effect on low flow and how the indices were determined.

Values for these basin characteristics for low-flow partial-record stations and selected gaging stations in the basin are listed in table 2 .

Drainage area (A).--Size of the drainage area is the most significant characteristic in explaining differences in streamflow between sites. Because low flow is ground-water runoff, the contributing area is defined by the ground-water divide of a basin which can be determined from potentiometric maps. Because detailed potentiometric maps are not available for most areas in this basin, the surface-water divide was used to define the contributing drainage area. Owing to the relatively steep relief, the difference between the area of ground-water drainage and surface-water drainage is probably slight.

Drainage areas, in square miles, were computed from U.S. Geological Survey topographic and planimetric maps. Most drainage-area data for this study were obtained from Holmstrom (1972).

Main-channel slope (S).--Main-channel slope (Benson, 1962 and 1964) is a characteristic that relates to the change in streamflow for different basins. The index of slope used in this analysis is the average slope in feet per mile between points 10 percent and 85 percent of the distance upstream from the gaged site to the drainage-basin divide. 
Main-channel length ( $I$ ).--Main-channel length is another landform characteristic that indicates basin shape in conjunction with drainage area of the basin. In estimating ground-water runoff to the stream, I can be viewed as describing the length of the vertical cross-sectional area of the porous aquifer material through which the flow occurs. Channel length was obtained from the U.S. Geological Survey topographic maps by measuring the total indicated blue-line length by a digitizer, divider, or other means.

Basin storage (BS).--Basin storage is that part of total drainage area occupied by lakes and marshes. Variations in streamflow can be caused by retention and release of water from basin storage. For some streams, runoff is delayed by storage, but total runoff may not be reduced; whereas on other streams prolonged retention allows increased evapotranspiration which results in decreased runoff. Essentially, the basin storage index is used in the analysis to reflect the effect of evapotranspiration on low flow.

The basin storage area was obtained from U.S. Geological Survey topographic maps. A value of 1.00 percent was added to all values of basin storage to avoid problems of using zero in the regression analysis.

Forest cover (F).--Forests affect streamflow in several ways. Their major influences on low flow are intercepting precipitation before it reaches the ground and transpiration.

The forest cover index used in this analysis is the percentage of drainage area covered by forests as shown on U.S. Geological Survey topographic maps. A value of 1.00 percent was added to all values of forest cover to avoid problems of using zero in the regression analysis.

Mean annual precipitation (P).--Mean annual precipitation of a basin is the amount of water available for potential runoff. The precipitation that recharges the ground-water aquifer is the source of base flow for a stream. The mean annual precipitation, in inches, for each basin was computed from an isohyetal map determined from precipitation recorded in the 1931-60 period (Wisconsin Statistical Reporting Service, 1967, p. 18) (fig. 7).

A constant of $20 \mathrm{in.}$. was subtracted from each value for use in the regression analysis making constants and coefficients in the regression equation more manageable.

Soil-infiltration rate (I).--Soil permeability influences the amount of direct runoff from a storm and the amount of water that infiltrates the soil. The permeability used is an average rate for the basin under average soil and moisture conditions.

Soil types and average permeability, in inches per hour, for each basin were determined from a map from Young and Borman (1973, sheet 1) (p1. 3). 


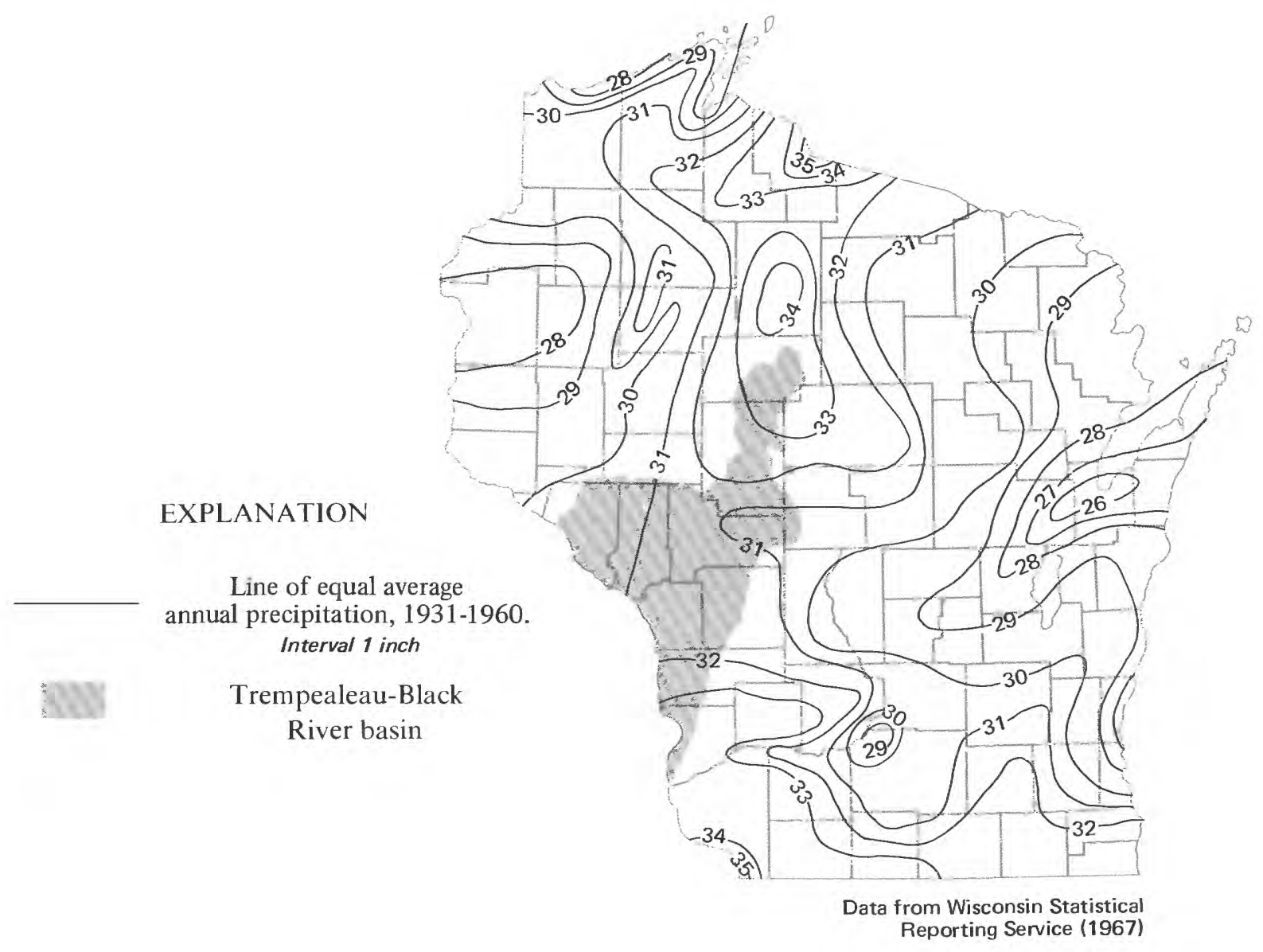

Figure 7. Average annual precipitation.

Mean annual snowfall ( $\mathrm{Sn}$ ).--Mean annual snowfall, like mean annual precipitation, is an indicator of water available for runoff. For each basin an average mean annual snowfall, in inches, was determined from an isohyetal map determined from snowfall recorded during 1930-59 (Wisconsin Statistical Reporting Service, 1970, p. 1) (fig. 8) and average snowfall values from National Weather Service weather stations (Wisconsin Crop Reporting Service, 1961). A constant of 20 in. was subtracted from each value to provide more manageable constants and coefficients in the equations.

Base-flow index (Bf).--A good indicator of a stream's low-flow potential is a discharge measurement made during base-flow conditions. Base-flow measurements provide considerable information about the characteristics of the aquifers supplying outflow to the stream. To use base-flow measurements, it is necessary to convert them to a uniform basis because measurements are generally obtained at various points on the base-flow recession curves. 


\section{EXPLANATION}

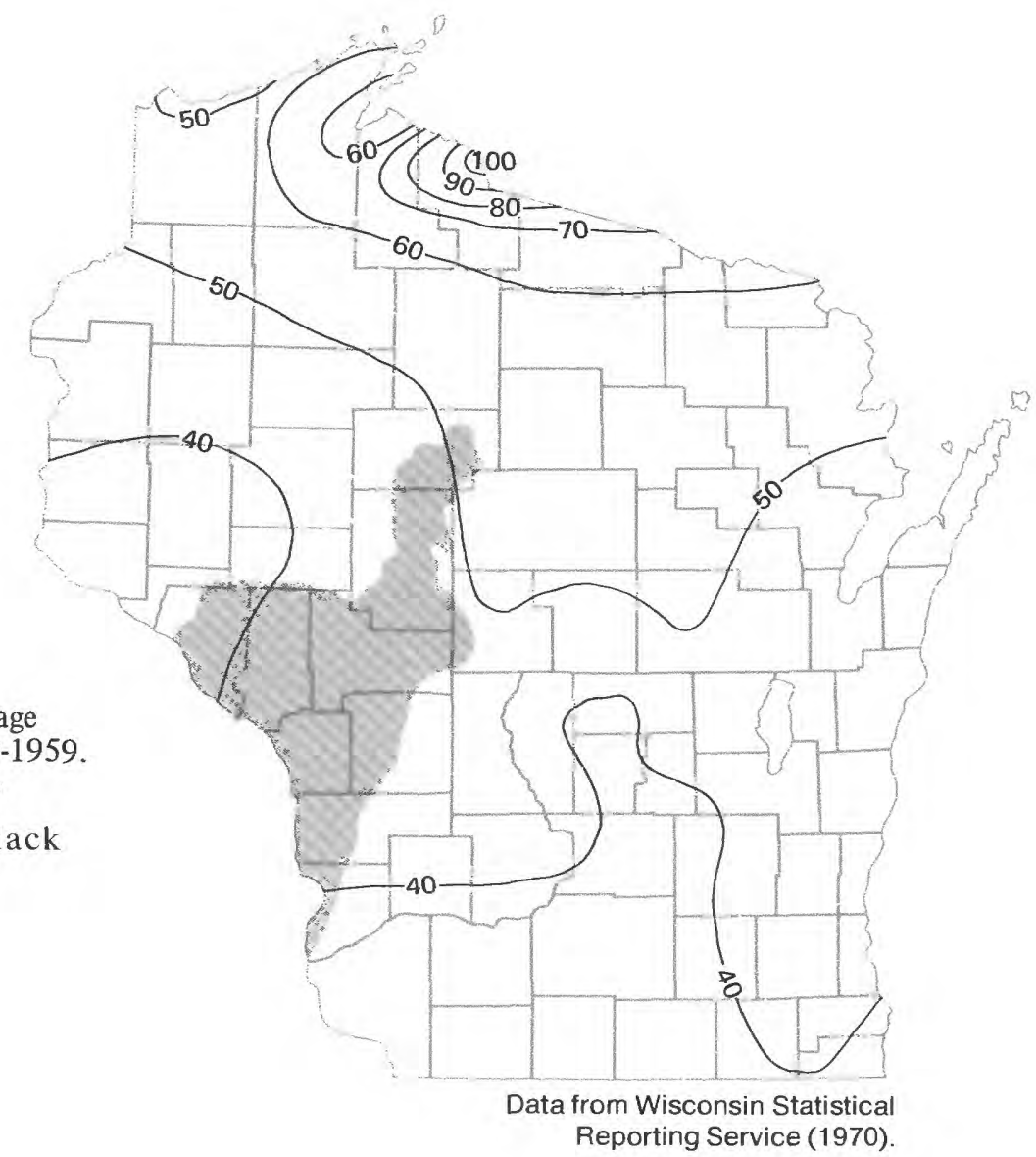

Figure 8. Average annual snowfall.

Discharge at the 90 percent flow duration was selected to represent the base-flow index value. To evaluate the technique and develop the necessary relationships for this study, sites were selected that had discharge measurements obtained for a low-flow investigation during August 10-13, 1970.

Measured discharges $\left(Q_{m}\right)$ at low-flow partial-record stations and miscellaneous sites were converted to a unit discharge by dividing the values by their respective drainage areas (A). These values then were adjusted by a basin ratio to determine the base-flow index for each site. Basin ratios were determined for gaging stations on unregulated streams within the Trempealeau-Black River basin by dividing the discharge at 90 percent flow duration (Q9o) by the observed average daily discharge during August 10-13, $1970\left(Q_{r}\right)$. Thus, base-flow index values were determined by the equation: 


$$
B f=\frac{Q_{m} Q_{90}}{A Q_{r}}
$$

Plate 4 shows the locations of 66 sites with base-flow index values, their respective drainage-area outlines, and their computed base-flow index values.

Hydraulic conductivity $(K)$.--Hydraulic conductivity of an aquifer is the volume of water at the existing kinematic viscosity that will move in unit time under a unit hydraulic gradient through a unit area measured at right angles to the direction of flow. Average values of hydraulic conductivity were given to the glacial drift in the Trempealeau-Black River basin and are:

\author{
Hydraulic \\ conductivity \\ $\underline{\left\{(\mathrm{gal} / \mathrm{d}) / \mathrm{ft} \mathrm{t}^{2}\right\}}$
}

Lake basins (clay, silt, and sand)

Ground moraine (till; consists of clay, silt, sand, gravel, and boulders )

End moraine (till; sand and gravel)

Outwash (sand and gravel)
1

10

100

2,500

Average values of hydraulic conductivity were obtained for each of the subbasins in the glaciated area by the following procedure: (1) outline subbasin divide on glacial geology map (pl. 1), (2) determine the subareas for each of the glacial drift types, (3) multiply these subareas by the hydraulic conductivity values assigned to the glacial drift, and (4) divide the sum of these products by the sum of the subareas.

Drift thickness (H).--Glacial drift serves as an aquifer that stores water for release to streams. The drift covers only about one-fourth of the basin, a large percentage of which is in the upper part of the Black River subbasin. Its thickness ranges from zero in the "Driftless Area" to $200 \mathrm{ft}$ in the Mississippi River valley. An average drift thickness for each subbasin was determined from the glacial geology and drift thickness $\operatorname{map}(\mathrm{pl} .1)$.

Transmissivity (T).--The water-transmitting capability of an aquifer is expressed in terms of transmissivity. Values of transmissivity were obtained by the product of hydraulic conductivity and drift thickness.

\title{
REGRESSION ANALYSIS
}

Multiple-regression analysis was used to determine the relationship between the low-flow characteristics (dependent variables) and the basin characteristics (independent variables). The analysis provides an equation, or series of equations, relating the dependent to the independent variables. This analysis defined mathematical equations of the form: 


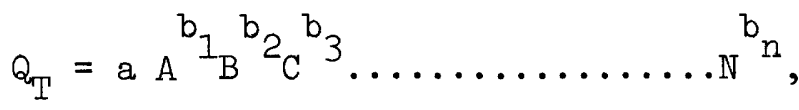

where:

$Q_{T}$ is a 7-day low-flow characteristic having a T-year recurrence interval, in cubic feet per second;

a is a regression constant defined by the regression analysis;

$A B C \ldots . N$ are drainage-basin characteristics; and

$b_{1} b_{2} b_{3} \cdots b_{n}$ are coefficients defined by regression analysis.

The analysis also defined the standard error of estimate (SE) of the dependent variables and the statistical significance of each variable in the equation.

The standard error of estimate is a measure of the accuracy of the regression relationships. It describes a range in error between the defined relationship and the data included in the analysis. Values estimated by the regression equations are within the range of one standard error of estimate at 67 percent of the sites and within twice this range for 95 percent of the sites.

Step-backward regression analyses were performed by digital computer using procedures outlined by Thomas and Benson (1970, p. 26-31). The equations with the lowest standard error of estimate with all variables significant at the 99 percent or the 95 percent confidence level were selected as the best equations for prediction.

Two separate sets of analyses were performed in an attempt to develop equations for sites with no streamflow data available and for sites where some streamflow data are available. These analyses were done for stations in the "Driftless Area" and again for stations in the glaciated area.

\section{SITES WITHOUT STREAMFLOW DATA}

Two multiple-regression analyses were run to develop equations in the "Driftless Area" and in the glaciated area (pl. 1) for sites without streamflow data. These analyses included all the basin characteristics given in table 2 except for the base-flow index. Drainage area, soilinfiltration rate, and transmissivity were the only basin characteristics that were significant.

The analysis for the "Driftless Area" was run using data for 3 gaging stations and 13 low-flow partial-record stations in the Trempealeau-Black River basin. Equations 1 and 2 were selected from this analysis. The analysis for the glaciated area was run using data for 3 low-flow partialrecord stations $\left(Q_{7}, 10>0.01 \mathrm{ft} 3 / \mathrm{s}\right)$ in the Trempealeau-Black River basin and 12 low-flow partial-record stations in adjoining basins. Equations 3 and 
4 were selected from this analysis. The four equations and their respective standard error of estimates are:

$$
\begin{aligned}
& \text { Equation } \\
& Q_{7,2}=0.291 \mathrm{~A}^{1.02} \\
& \text { Applicable to } \\
& \text { "Driftless Area" } \\
& \underline{\text { Standard error }} \\
& Q_{7,10}=0.174 \mathrm{~A}^{1.07} \\
& \text { "Driftless Area" } \\
& 30 \text { percent } \\
& Q_{7,2}=1.45 \times 10^{-2} A^{1.12} I^{0.480} \\
& \text { Glaciated area } \\
& 37 \text { percent } \\
& Q_{7,10}=9.18 \times 10^{-5} \mathrm{~A}^{1.37_{\mathrm{T}}} 0.361 \\
& \text { Glaciated area } \\
& 77 \text { percent } \\
& 105 \text { percent }
\end{aligned}
$$

\section{SITES WITH MINIMUM STREAMFLOW DATA}

Two multiple-regression analyses were run to develop equations in the "Driftless Area" and in the glaciated area (pl. I) for use at sites with one or two discharge measurements. The equations and their respective standard errors of estimate are:

\section{Equation}

$$
\begin{aligned}
& Q_{7,2}= 3.09 \times 10^{-3} A^{1.02} P^{2.21} \\
& I^{0.158}{ }_{B f} 0.693
\end{aligned}
$$$$
Q_{7,2}=0.655 \mathrm{~A}^{1.02} \mathrm{Bf}^{0.694}
$$$$
Q_{7,10}=9.42 \times 10^{-4} \mathrm{~A}^{1.07} \mathrm{P}^{1.51}
$$$$
\mathrm{Sn}^{0.790} \mathrm{Bf}^{0.836}
$$$$
Q_{7,10}=0.452 \mathrm{~A}^{1.08} \mathrm{Bf}^{0.817}
$$

\section{Applicable to}

\section{Standard error}

$$
\text { "Driftless Area" } 10 \text { percent }
$$

"Driftless Area"

16 percent

17 percent 


\section{Equation}

$Q_{7,2}=0.539 \mathrm{~A}^{1.07} \mathrm{Bf}^{0.997}$

$\mathrm{Q}_{7,10}=0.434 \mathrm{~A}^{1.04} \mathrm{Bf}^{1.23}$

$Q_{7,2}, Q_{7,10}, A$, and $I$ are as defined for equations 1 through 4;

$P$ is the mean annual precipitation minus 20 , in inches;

$\mathrm{Bf}$ is the base-flow index, in cubic feet per second per square mile; and

$\mathrm{Sn}$ is the mean annual snowfall minus 20 , in inches.

Equations 6 and 8 are provided because they have slightly higher standard errors than equations 5 and 7 and are easier to apply. Equations 6, 8,9 , and 10 were used to compute the low-flow characteristics at miscellaneous sites with one or two discharge measurements and with drainage areas less than $150 \mathrm{mi}^{2}$ (table 1 ).

Equations 5, 7, 9, and 10 should provide estimates of $Q_{7,2}$ and $0.7,10$ at approximately the SE given for the equation for sites where base-flow measurements have been made. In addition, for sites without streamflow data and not on small tributaries, equations 5 through 10 should provide more reliable estimates than equations 1 through 4 for the following conditions:

1. For ungaged sites in an area where the degree of uniformity among Bf values is high, as shown on plate 4.

2. For ungaged sites within the indicated subbasins on plate 4 .

\section{VERIFICATION OF REGRESSION EQUATIONS THAT USE BASE-FLOW INDEX}

To test the validity of equations 5 and 7 , low-flow characteristics were determined by these equations using streamflow data collected at 13 low-flow partial-record stations in the "Driftless Area" during three different periods. Periods selected for the analyses were: a low baseflow period (flow durations greater than 80 percent), August 17-19, 1964; a medium base-flow period (flow durations 60-80 percent), July 6-9, 1970; and a high base-flow period (flow durations less than 60 percent), August 1820, 1969. Equations 9 and 10 also were tested using streamflow data collected at 15 low-flow partial-record stations in the glaciated area. Periods selected for analyses were: a low base-flow period, July 8-11, 1963; a medium base-flow period, June 23-24, 1966; and a high base-flow period, November 1-3, 1965. Values of Bf were obtained for each period as outlined previously. The $Q_{7,2}$ and $Q_{7,10}$ values computed for these periods using equations $5,7,9$, and 10 were compared to the 87,2 and 87,10 values listed in table 1 , and the following SE's were graphicaliy determined. 


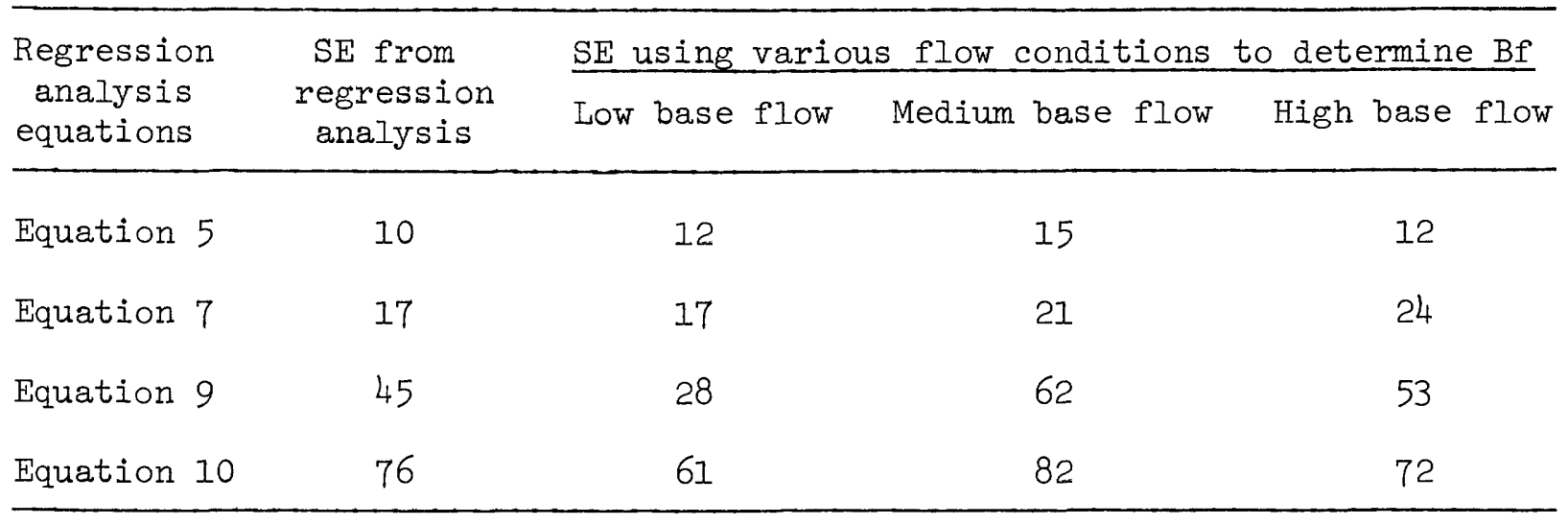

As illustrated, equations $5,7,9$, and 10 produce satisfactory results for other sets of flow conditions than were used for their development.

\section{APPLICATION OF ESTIMATING PROCEDURES}

\section{SITES WITHOUT STREAMFLOW DATA}

Computation of low-flow characteristics at an ungaged site in the "Driftless Area" (pl. 2) may be made as follows:

1. If the conditions listed on page 19 are met, use equations 5 through 8 (page 18) to determine the low-flow characteristics at ungaged sites.

2. Determine base-flow index from plate 4.

3. Compute the other basin characteristics, drainage area, mean annual precipitation, soil-infiltration rate, and mean annual snowfall as outlined on pages 12,13 , and 14.

4. Substitute these values into equations 5 through 8 and solve for the low-flow characteristics.

5. Use equations 1 and 2 (page 18) to determine the low-flow characteristics for sites where the conditions outlined on page 19 cannot be met.

6. Compute the drainage area as indicated on page 12 .

7. Substitute these values into equations 1 and 2 and solve for the low-flow characteristics.

For ungaged sites in the "Driftless Area" where the degree of uniformity of base-flow index values is high, Bf can be determined from plate 4, and equations 5 through 8 can be used to determine the low-flow characteristics. For example, to determine the low-flow characteristics of Trempealeau 
River, just downstream from the confluence with French Creek near Taylor, the applicable equations are:

$$
\begin{aligned}
& Q_{7,2}=3.09 \times 10^{-3} \mathrm{~A}^{1.02} \mathrm{P}^{2.21} \mathrm{I}^{0.158} \mathrm{Bf}^{0.693} \\
& \mathrm{Q}_{7,10}=9.42 \times 10^{-4} \mathrm{~A}^{1.07} \mathrm{P}^{1.51} \mathrm{Sn}^{0.790} \mathrm{Bf}^{0.836}
\end{aligned}
$$

Drainage area was determined as outlined on page 12 and is $139 \mathrm{mi}^{2}$.

The average precipitation is approximately 31 in. (fig. 7). A constant of $20 \mathrm{in}$. has to be subtracted. Therefore, $P=31$ in. -20 in. $=11$ in.

The average soil-infiltration rate was determined from plate 3 and is about $2.3 \mathrm{in} / \mathrm{hr}$.

The base-flow index is determined from plate 4 and is a weighted average based on drainage area.

$$
\begin{aligned}
& \mathrm{Bf}=\frac{\mathrm{A}_{1} \mathrm{Bf}_{1}+\mathrm{A}_{2} \mathrm{Bf}_{2}}{\mathrm{~A}_{1}+\mathrm{A}_{2}} \\
& \mathrm{Bf}=\frac{110(0.31)+(29)(0.28)}{139}=\frac{34.1+8.12}{139} \\
& \mathrm{Bf}=0.30
\end{aligned}
$$

where: $\quad A_{1}=$ drainage area at station $05379200=110 \mathrm{mi}^{2}$,

$$
\mathrm{Bf}_{I}=\text { base-flow index at station } 05379200=0.31 \text {, }
$$$$
\begin{gathered}
\mathrm{A}_{2}=\text { intervening drainage area between site of interest and } \\
\text { station } 05379200=29 \mathrm{mi} \text {, and }
\end{gathered}
$$
station $05379200=29 \mathrm{mi}^{2}$, and

$$
\begin{gathered}
\mathrm{Bf}_{2}=\text { base-flow index for intervening area between site of } \\
\text { interest and } 05379200=0.28 .
\end{gathered}
$$

The mean annual snowfall is approximately 46 in. (fig. 8). A constant of $20 \mathrm{in.} \mathrm{has} \mathrm{to} \mathrm{be} \mathrm{subtracted.} \mathrm{Therefore,} \mathrm{Sn}=46 \mathrm{in} .-20 \mathrm{in} .=26 \mathrm{in}$.

Substituting these values into their respective equations:

$$
\begin{aligned}
Q_{7,2} & =3.09 \times 10^{-3} \mathrm{~A}^{1.02} \mathrm{P}^{2.21} \mathrm{I}^{0.158} \mathrm{Bf}^{0.693} \\
& =3.09 \times 10^{-3}(139)^{1.02}(11)^{2.21}(2.3)^{0.158}(0.30)^{0.693} \\
& =3.09 \times 10^{-3}(153)(200)(1.1)(0.43) \\
& =45 \mathrm{ft}^{3} / \mathrm{s}
\end{aligned}
$$




$$
\begin{aligned}
Q_{7,10} & =9.42 \times 10^{-4} \mathrm{~A}^{1.07} \mathrm{P}^{1.51_{\mathrm{Sn}} 0.790_{\mathrm{Bf}} 0.836} \\
& =9.42 \times 10^{-4}(139)^{1.07}(11)^{1.51}(26)^{0.790}(0.30)^{0.836} \\
& =9.42 \times 10^{-4}(196)(37)(13)(0.37) \\
& =33 \mathrm{ft}^{3} / \mathrm{s}
\end{aligned}
$$

Low-flow characteristics for ungaged sites in which conditions on page 19 are not met can be determined by regression equations 1 and 2. The low-flow characteristics of Fish Creek near Rockland are determined to illustrate the application of equations 1 and 2 :

$$
\begin{aligned}
& Q_{7,2}=0.291 \mathrm{~A}^{1.02} \\
& Q_{7,10}=0.174 \mathrm{~A}^{1.07}
\end{aligned}
$$

The drainage area was determined as outlined on page 12 and is $15.2 \mathrm{mi}^{2}$. Substituting this value into the respective equation:

$$
\begin{aligned}
Q_{7,2} & =0.291 \mathrm{~A}^{1.02} \\
& =0.291(15.2)^{1.02} \\
& =0.291(16.1) \\
& =4.7 \mathrm{ft}^{3} / \mathrm{s} \\
Q_{7,10} & =0.174 \mathrm{~A}^{1.07} \\
& =0.174(15.2)^{1.07} \\
& =0.174(18.4) \\
& =3.2 \mathrm{ft}^{3} / \mathrm{s}
\end{aligned}
$$

Computation of low-flow characteristics at an ungaged site in the glaciated area ( $\mathrm{pl} .2$ ) may be made as follows:

1. If the conditions listed on page 19 are met, use equations 9 and 10 (page 19) to determine the low-flow characteristics at ungaged site.

2. Determine drainage area as outlined on page 12.

3. Determine base-flow index from plate 4.

4. Substitute these values into equations 9 and 10 and solve for the low-flow characteristics. 
5. Use equations 3 and 4 listed on page 18 to determine the low-flow characteristics for sites where the conditions outlined on page 19 cannot be met.

6. Determine the drainage area as outlined on page 12, soilinfiltration rate as indicated on page 13, and transmissivity as indicated on page 16.

7. Substitute these values into equations 3 and 4 and solve for the low-flow characteristics.

For ungaged sites within the indicated subbasins on plate 4 , the $\mathrm{Bf}$ value can be obtained from plate 4 , and equations 9 and 10 can be used to determine the low-flow characteristics. For example, to determine the lowflow characteristics of South Fork Poplar River, directly upstream from the confluence with East Fork Poplar River near Riplinger, the applicable equations are:

$$
\begin{aligned}
Q_{6,2} & =0.539 \mathrm{~A}^{1.07} \mathrm{Bf}^{0.997} \\
Q_{7,10} & =0.434 \mathrm{~A}^{1.04} \mathrm{Bf}^{1.23}
\end{aligned}
$$

Drainage area was determined as outlined on page 12 and is $25.6 \mathrm{mi}^{2}$.

Base-flow index is determined from plate 4 and is 0.016 .

Substituting these values into the respective equations:

$$
\begin{array}{rl}
Q_{7,2} & =0.539 \mathrm{~A}^{1.07} \mathrm{Bf}^{0.997} \\
& =0.539(25.6)^{1.07}(0.016)^{0.997} \\
& =0.539(32.1)(0.016) \\
& =0.28 \mathrm{ft}^{3 / \mathrm{s}} \\
Q_{7,10} & 0.434 \mathrm{~A}^{1.04} \mathrm{Bf}^{1.23} \\
& =0.434(25.6)^{1.04}(0.016)^{1.23} \\
& =0.434(29.1)(0.0062) \\
& =0.08 \mathrm{ft}^{3 / \mathrm{s}}
\end{array}
$$

Low-flow characteristics for ungaged sites in which conditions on page 19 are not met can be determined by regression equations 3 and 4 . The lowflow characteristics of Joe Creek near Perkinstown at the mouth are determined to illustrate the application of equations 3 and 4 : 


$$
\begin{aligned}
Q_{7,2} & =1.45 \times 10^{-2} \mathrm{~A}^{1.12} \mathrm{I}^{0.480} \\
\mathrm{Q}_{7,10} & =9.18 \times 10^{-5} \mathrm{~A} 1.37_{\mathrm{T}} 0.361
\end{aligned}
$$

The drainage area was determined as outlined on page 12 and is $8.84 \mathrm{mi}^{2}$.

The soil-infiltration rate (pl. 3) has a range from 0.8 to $2.5 \mathrm{in} / \mathrm{hr}$ under a $0.5 \mathrm{in.} \mathrm{head.} \mathrm{Using} \mathrm{an} \mathrm{average} \mathrm{value,} \mathrm{I} \mathrm{is} 1.65 \mathrm{in} / \mathrm{hr}$.

The hydraulic conductivity and drift thickness are determined from the glacial geology and drift thickness map (pl. 1). Approximately $0.3 \mathrm{mi} 2$ of the basin contains pitted outwash $\{\mathrm{K}=2,500$ (gal/d)/ft2 $\}$ and $8.54 \mathrm{mi} 2$ contains end moraine $\left\{\mathrm{K}=100(\mathrm{gal} / \mathrm{d}) / \mathrm{ft}^{2}\right\}$. The average value of hydraulic conductivity $(K)$ is $\frac{0.3 \times 2,500+8.54 \times 100}{8.84}=180(\mathrm{gal} / \mathrm{d}) / \mathrm{ft}^{2}$. The drift

thickness $(H)$ is about $100 \mathrm{ft}$. Hence transmissivity $(\mathrm{T})=(\mathrm{K})(\mathrm{H})=180$ $X 100=18,000(\mathrm{gal} / \mathrm{d}) / \mathrm{ft}$. Substituting these values into their respective equations :

$$
\begin{aligned}
Q_{7,2} & =1.45 \times 10^{-2} \mathrm{~A}_{\mathrm{I}}^{1.12} 0.480 \\
& =1.45 \times 10^{-2}(8.84)^{1.12}(1.65)^{0.480} \\
& =1.45 \times 10^{-2}(11.5)(1.27) \\
& =0.21 \mathrm{ft}^{3} / \mathrm{s} \\
Q_{7,10} & =9.18 \times 10^{-5} \mathrm{~A}^{1.37_{\mathrm{T}} 0.361} \\
& =9.18 \times 10^{-5}(8.84)^{1.37}(18,000)^{0.361} \\
& =9.18 \times 10^{-5}(19.8)(34.4) \\
& =0.06 \mathrm{ft}^{3} / \mathrm{s}
\end{aligned}
$$

\section{SITES WITH MINIMUM STREAMFLOW DATA}

Computation of the low-flow characteristics at sites in the "Driftless Area" with minimum streamflow data available is made as follows:

1. Use equations 5 and 7 listed on page 18 to determine the low-flow characteristics.

2. Determine from plate 2 and table 1 the type of streamflow data that are available.

3. If the streamflow measurements are made during base-flow conditions, the $\mathrm{Bf}$ should be determined as outlined on pages 14, 15, and 16. 
4. Compute the other basin characteristics, drainage area, mean annual precipitation, soil-infiltration rate, and mean annual snowfall, used in the equation as outlined on pages 12,13 , and 14 .

5. Substitute values determined in steps 3 and 4 into equations 5 and 7 .

The following procedure would be used to determine the low-flow characteristics of Fly Creek near Whitehall (station number 05379275).

The applicable equations for a station in the "Driftless Area" with minimum streamflow data available are:

$$
\begin{aligned}
Q_{7,2} & =3.09 \times 10^{-3} \mathrm{~A}^{1.02} \mathrm{P}^{2.21} \mathrm{I}^{0.158} \mathrm{Bf}_{\mathrm{Bf}}^{0.693} \\
\mathrm{Q}_{7,10} & =9.42 \times 10^{-4} \mathrm{~A}^{1.07} \mathrm{P}^{1.5 I_{\mathrm{Sn}}} 0.790_{\mathrm{Bf}} 0.836
\end{aligned}
$$

Drainage area (A) obtained from table 1, page 12, is $10.2 \mathrm{mi}^{2}$.

The mean annual precipitation is approximately $31.2 \mathrm{in.} \mathrm{(fig.} \mathrm{7).} \mathrm{A}$ constant of $20 \mathrm{in}$. has to be subtracted. Therefore, $P=31.2-20=$ 11.2 in.

An average soil-infiltration rate for the basin (pl. 3) has a range of 0.8 to $2.5 \mathrm{in} / \mathrm{hr}$ under a $0.5 \mathrm{in}$. head. Using an average value, I is $1.65 \mathrm{in} / \mathrm{hr}$.

The mean annual snowfall for the basin is approximately 46 in. A constant of $20 \mathrm{in}$. has to be subtracted. Therefore, $\mathrm{Sn}=46-20=26 \mathrm{in}$.

The base-flow index cannot be obtained from plate 4 because a baseflow measurement was not obtained during the August 10-13, 1970, period. Therefore, a $\mathrm{Bf}$ value has to be determined from the base-flow measurement that is available. Following the same general procedure indicated on pages 14,15 , and 16, a Bf value was determined by the equation:

$$
B f=\frac{Q_{m}{ }^{Q_{90}}}{A Q_{r}}
$$

where: $Q_{m}$ is the measured discharge, $2.60 \mathrm{ft}^{3} / \mathrm{s}$, of Fly Creek near Whitehall on August 19, 1970;

$A$ is the drainage area, $10.2 \mathrm{mi}^{2}$, of Fly Creek near Whitehall;

$Q_{r}$ is the recorded discharge at a nearby continuous-record gaging station. Referring to plate 1, station 05379500 , Trempealeau River at Dodge is the closest active gaging station. From "Water Resources Data for Wisconsin" (1972) the 
average daily discharge for August 19, 1970, was $230 \mathrm{ft}^{3} / \mathrm{s}$; and $Q_{90}$ for Trempealeau River at Dodge is $183 \mathrm{ft}^{3} / \mathrm{s}$, obtained from
table 1 .

Substituting these values in the equation:

$$
\begin{aligned}
\mathrm{Bf} & =\frac{Q_{m} Q_{90}}{A Q_{r}} \\
& =\frac{(2.60)(183)}{(10.2)(230)} \\
& =0.203\left(\mathrm{ft}^{3} / \mathrm{s}\right) / \mathrm{mi}^{2}
\end{aligned}
$$

The low-flow characteristics then can be determined by substituting these values in their respective equations.

$$
\begin{aligned}
& \mathrm{Q}_{7,2}=3.09 \times 10^{-3} \mathrm{~A}^{1.02} \mathrm{P}^{2.21} \mathrm{I}^{0.158} \mathrm{Bf}^{0.693} \\
& =\left(3.09 \times 10^{-3}\right)(10.2)^{1.02}(11.2)^{2.21}(1.65)^{0.158}(0.203)^{0.693} \\
& =\left(3.09 \times 10^{-3}\right)(10.7)(208)(1.08)(0.331) \\
& =2.5 \mathrm{ft}^{3} / \mathrm{s} \\
& Q_{7,10}=9.42 \times 10^{-4} \mathrm{~A}^{1.07} \mathrm{P}^{1.51} \mathrm{Sn}^{0.790} \mathrm{Bf}^{0.836} \\
& =\left(9.42 \times 10^{-4}\right)(10.2)^{1.07}(11.2)^{1.51}(26)^{0.790}(0.203)^{0.836} \\
& =\left(9.42 \times 10^{-4}\right)(12.0)(38.4)(13)(0.264) \\
& =1.5 \mathrm{ft}^{3} / \mathrm{s}
\end{aligned}
$$

\section{COMPARISON OF METHODS}

If estimates of low-flow characteristics are required at sites other than those presented in this report, the user interested in the data should evaluate the need for the low-flow information and then select a method based on the following criteria. Generally the most important criteria in choosing a method are: accuracy requirements of the low-flow characteristics; time available to collect and analyze data; and cost of data collection and analyses.

Tables 3 and 4 compare the methods available and provide: type of data required; number of sites where required data are available; time 
required to collect data; analytical method used to determine the low-flow characteristics; and standard error of estimate associated with the method. If a high degree of reliability is required of low-flow characteristics and sufficient time is available for data collection, a gaging station or lowflow partial-record station can be operated. If a lesser degree of reliability is acceptable at a site or time and money are limited, three base-flow discharge measurements can be obtained, or one of the regression equations may be sufficient.

\section{SUMMARY}

Low-flow characteristics were determined for 9 gaging stations, 20 lowflow partial-record stations, and 119 miscellaneous sites in the TrempealeauBlack River basin.

The method used in estimating the low-flow characteristics was dependent on the amount of discharge data available at the site. The low-flow characteristics at a gaging station with 10 or more years of record were determined by a log-Pearson Type III frequency analysis or plotting-position analysis. At a low-flow partial-record station ( 7 or more discharge measurements) or miscellaneous site ( 3 or more discharge measurements) a graphical correlation was used to determine the 27,2 and $Q_{7,10}$. At miscellaneous sites ( 1 or 2 discharge measurements) and ungaged sites (no discharge measurements) multiple-regression equations were developed to determine the low-flow characteristics.

The standard error of estimate of the 7-day, 10-year low flow $\left(\mathrm{SE}_{7}, 10\right)$ was provided. The average $\mathrm{SE}_{7,10}$ in the "Driftless Area" of the basin ranged from 6 to 37 percent, depending on the type of data available. For the glaciated area of the basin the average $S_{7}, 10$ ranged from 23 to 105 percent. The methods used to determine the standard errors are not precise and should be used as a relative guide to indicate a general level of confidence.

\section{REFERENCES}

Benson, M. A., 1962, Factors influencing the occurrence of floods in a humid region of diverse terrain: U.S. Geological Survey Water-Supply Paper 1580-B, $64 \mathrm{p}$.

1964, Factors affecting the occurrence of floods in the Southwest:

U.S. Geological Survey Water-Supply Paper 1580-D, 72 p.

Gebert, W. A., 1971, Low-flow frequency of Wisconsin streams: U.S. Geological Survey Hydrologic Investigations Atlas HA-390.

Gebert, W. A., and Holmstrom, B. K., 1974, Low-flow characteristics of Wisconsin streams at sewage-treatment plants: U.S. Geological Survey Water-Resources Investigations 45-74, $101 \mathrm{p}$. 
Hardison, C. H., and Moss, M. E., 1972, Accuracy of low-flow characteristics estimated by correlation of base-flow measurements: U.S. GeologicaI Survey Water-Supply Paper 1542-B, 21 p.

Hole, F. D., Beatty, M. T., Milford, C. J., Lee, G. B., and Klingelhoets, A. J., 1968, Soils of Wisconsin: Wisconsin Geological and Natural History Survey map.

Holmstrom, B. K., 1972, Drainage-area data for Wisconsin streams: U.S. Geological Survey open-file report, $76 \mathrm{p}$.

Riggs, H. C., 1972, Low-flow investigations: U.S. Geological Survey Techniques of Water-Resources Investigations, book 4, chap. BI, $18 \mathrm{p}$.

Thomas, D. M., and Benson, M. A., 1970, Generalization of streamflow characteristics from drainage-basin characteristics: U.S. Geological Survey Water-Supply Paper 1975, 55 p.

Thwaites, F. T., 1956, Glacial features of Wisconsin: Wisconsin Geological and Natural History Survey open-file map.

U.S. Geological Survey, 1972, Water resources data for Wisconsin, 1970: U.S. Geological Survey Annual Report, 259 p.

U.S. Soil Conservation Service, 1964, Engineering test data and interpretations for major soils of Wisconsin: Madison, $70 \mathrm{p}$.

Wisconsin Crop Reporting Service, 1961, Wisconsin climatological data: Madison, Wisconsin Department of Agriculture, $166 \mathrm{p}$.

Wisconsin Legislative Reference Bureau, 1977, The State of Wisconsin 1977 Blue Book: Madison, Department of Administration, Document Sales and Distribution, $986 \mathrm{p}$.

Wisconsin Statistical Reporting Service, 1967, Wisconsin weather: Madison, Wisconsin Statistical Reporting Service, $31 \mathrm{p}$.

1970, Snow and frost in Wisconsin: Madison, Wisconsin Statistical Reporting Service, $28 \mathrm{p}$.

Young, H. L., and Borman, R. G., 1973, Water resources of Wisconsin-Trempealeau-Black River basin: U.S. Geological Survey Hydrologic Investigations Atlas HA-474. 
05371798 North Fork Buffalo River near Osseo, Wis.

Location. - - $\mathrm{SW} \frac{1}{4} \mathrm{SE} \frac{1}{4} \mathrm{sec} .3$, T. $24 \mathrm{~N} .$, R. 6 W., Jackson County, at bridge on Moe Road, 6.4 mi east of 0 sseo. Drainage area. $--9.2 \mathrm{mi}^{2}$. Tributary to.--Mississippi River.

Type of site.--Miscellaneous site.

Discharge measurement.--Aug. 12, $1970,3.04 \mathrm{ft}^{3} / \mathrm{s}$.

Low-flow frequency. $-Q_{7,2}=2.3 \mathrm{ft}^{3} / \mathrm{s}, Q_{7,10}=1.5 \mathrm{ft}^{3} / \mathrm{s}$.

Basis of estimate. - -Used regression equations 6 and 8 .

Accuracy. $--\mathrm{SE}_{7,2}=16$ percent, $\mathrm{SE}_{7,10}=22$ percent.

05371830 Buffalo River at Osseo, Wis.

Location.-- $-\mathrm{SW}_{\frac{1}{4}} \mathrm{NW} \frac{1}{4} \mathrm{sec} .9$, T. $24 \mathrm{~N} ., \mathrm{R} .7 \mathrm{~W} .$, Trempealeau County, at bridge on County Trunk $0,1.3$ mi west
of Osseo. Drainage area. $--73.7 \mathrm{mi}^{2}$. Tributary to. --Mississippi River.

Type of site.--Miscellaneous site.

Discharge measurements.--Aug. $9,1972,50.3 \mathrm{ft}^{3} / \mathrm{s} ;$ June $25,1973,68.8 \mathrm{ft}^{3} / \mathrm{s} ;$ Sept. $12,1973,40.0 \mathrm{ft} \mathrm{t}^{3} / \mathrm{s}$; Aug. $21,1976,19.7 \mathrm{ft}^{3} / \mathrm{s}$; Sept. $15,1977,17.1 \mathrm{ft} 3 / \mathrm{s}$.

Low-flow frequency.-- $Q_{7,2}=16 \mathrm{ft}^{3} / \mathrm{s}, Q_{7,10}=11 \mathrm{ft}^{3} / \mathrm{s}$.

Basis of estimate.--Correlated with Trempealeau River at Dodge using 5 discharge measurements.

Accuracy. $--\mathrm{SE}_{7,10}=19$ percent (basin average).

05371850 Buffalo River at Strum, Wis.

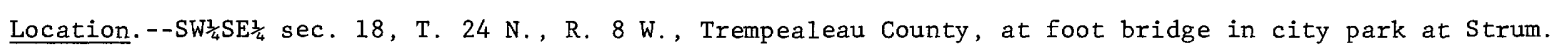
Drainage area. $--124 \mathrm{mi}^{2}$. Tributary to.--Mississippi River.

Type of site.--Miscellaneous site.

Discharge measurements.--Aug. $9,1972,77.9 \mathrm{ft}^{3} / \mathrm{s}$; June $26,1973,139 \mathrm{ft}^{3} / \mathrm{s}$; Sept. 12, 1973, $80.5 \mathrm{ft}^{3} / \mathrm{s}$; Aug. $21,1976,38.0 \mathrm{ft}^{3} / \mathrm{s}$; Sept. $15,1977,35.1 \mathrm{ft} 3 / \mathrm{s}$.

Low-flow frequency. $-Q_{7,2}=32 \mathrm{ft}^{3} / \mathrm{s}, Q_{7,10}=20 \mathrm{ft}^{3} / \mathrm{s}$.

Basis of estimate.--Correlated with Trempealeau River at Dodge using 5 discharge measurements.

Accuracy. $-\mathrm{SE}_{7,10}=19$ percent (basin average).

05371860 Buffalo River at Eleva, Wis.

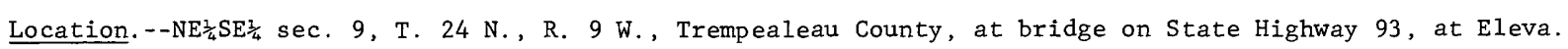
Drainage area. $--165 \mathrm{mi}^{2}$. Tributary to.--Mississippi River.

Type of site.--Miscellaneous site.

Discharge measurements. --Aug. 9, 1972, $96.4 \mathrm{ft}^{3} / \mathrm{s}$; June 26, 1973, $204 \mathrm{ft}^{3} / \mathrm{s}$; Sept. 12, $1973,112 \mathrm{ft}^{3} / \mathrm{s}$; Aug. $21,1976,54.7 \mathrm{ft} 3 / \mathrm{s}$; Sept. $15,1977,44.8 \mathrm{ft} / \mathrm{s}$.

Low-flow frequency. $-Q_{7,2}=38 \mathrm{ft}^{3} / \mathrm{s}, Q_{7,10}=23 \mathrm{ft}^{3} / \mathrm{s}$.

Basis of estimate.--Correlated with Trempealeau River at Dodge using 5 discharge measurements.

Accuracy. $--\mathrm{SE}_{7,10}=19$ percent (basin average). 


\section{Buffalo River near Mondovi, Wis.}

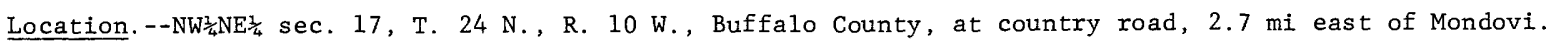
Drainage area. $--203 \mathrm{mi}^{2}$. Tributary to.--Mississippi River.

Type of site.-Miscellaneous site.

Discharge measurement.--Aug. 11, 1970, $90.5 \mathrm{ft}^{3} / \mathrm{s}$.

05371895 Buffalo River at Mondovi, Wis.

Location. - - NW $\frac{1}{4} \mathrm{SE} \frac{1}{4} \mathrm{sec} .14, \mathrm{~T} .24 \mathrm{~N} ., \mathrm{R} .11 \mathrm{~W}$. , Buffalo County, at sewage-treatment plant, $0.5 \mathrm{mi}$ downstream from County Trunk H bridge, at Mondovi.

Drainage area. $--238 \mathrm{mi}^{2}$. Tributary to.--Mississippi River.

Type of site.-Miscellaneous site.

Discharge measurements. --Aug. 9, 1972, $138 \mathrm{ft}^{3} / \mathrm{s} ;$ June $26,1973,278 \mathrm{ft}^{3} / \mathrm{s} ; 3^{\mathrm{Sept}} .12,1973,164 \mathrm{ft} / \mathrm{s}$;

Aug. $21,1976,85.7 \mathrm{ft}^{3} / \mathrm{s}$; Sept. $15,1977,85.7 \mathrm{ft}^{3} / \mathrm{s}$.

Low-flow frequency. $-\mathrm{Q}_{7,2}=64 \mathrm{ft}^{3} / \mathrm{s}, \mathrm{Q}_{7,10}=41 \mathrm{ft}^{3} / \mathrm{s}$.

Basis of estimate.--Correlated with Trempealeau River at Dodge using 5 discharge measurements.

Accuracy. $-\mathrm{SE}_{7,10}=19$ percent (basin average).

05371910 Harvey Creek at Mondovi, Wis.

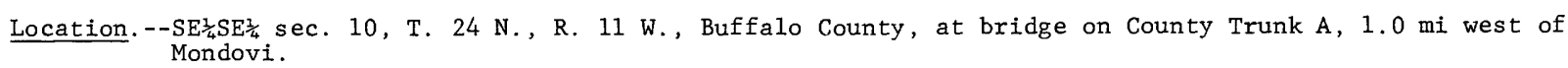
Drainage area. $--37.8 \mathrm{mi}^{2}$. Tributary to. --Buffalo River.

Type of site.--Miscellaneous site.

Discharge measurement.--Aug. $11,1970,9.07 \mathrm{ft}^{3} / \mathrm{s}$.

Low-flow frequency. - $-Q_{7,2}=7.6 \mathrm{ft}^{3} / \mathrm{s}, Q_{7,10}=5.3 \mathrm{ft}^{3} / \mathrm{s}$.

Basis of estimate.--Used regression equations 6 and 8 .

Accuracy. $--\mathrm{SE}_{7,2}=16$ percent, $S E_{7,10}=22$ percent.

05371960 Tamarack Creek at Modena, Wis.

Location. - $-\mathrm{SE} \frac{1}{4} \mathrm{SE} \frac{1}{4} \mathrm{sec} .23$, T. $23 \mathrm{~N} .$, R. $12 \mathrm{~W}$, Buffalo Creek, on County Trunk J, 0.2 mi south of Modena.

Drainage area. $--15.7 \mathrm{mi}^{2}$.

Tributary to. --Buffalo River.

Type of site.--Miscellaneous site.

Discharge measurement.--Aug. $12,1970,4.10 \mathrm{ft}^{3} / \mathrm{s}$.

Low-flow frequency. $-Q_{7,2}=3.3 \mathrm{ft}^{3} / \mathrm{s}, Q_{7,10}=2.2 \mathrm{ft}^{3} / \mathrm{s}$.

Basis of estimate.--Used regression equations 6 and 8 .

Accuracy.--SE $7,2=16$ percent, $\mathrm{SE}_{7,10}=22$ percent. 
05372000 Buffalo River near Tell, Wis.

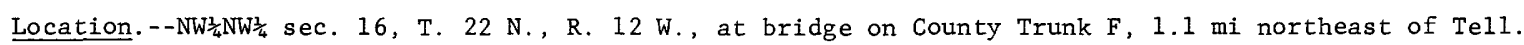
Drainage area. $--406 \mathrm{mi}^{2}$. Tributary to. --Mississippi River.

Type of site.--Gaging station.

Period of record.--October 1932 to September 1951, monthly discharge only for some periods.

Average discharge. $--254 \mathrm{ft}^{3} / \mathrm{s}, 19$ years.

Extremes.--Maximum discharge, 8,650 ft $\mathrm{ft}^{3} / \mathrm{s}$ Apr. 4, 1934; minimum observed, $59 \mathrm{ft}^{3} / \mathrm{s}$ Aug. $16,1933$.

\begin{tabular}{|c|c|c|c|c|c|}
\hline $\begin{array}{l}\text { Period } \\
\text { of con- } \\
\text { secutive } \\
\text { days }\end{array}$ & \multicolumn{5}{|c|}{$\begin{array}{l}\text { Magnitude and frequency of annual low flow } \\
\text { Discharge, in cubic feet per second, for } \\
\text { indicated recurrence interval, in years }\end{array}$} \\
\hline & 2 & 5 & 10 & 20 & 50 \\
\hline $\begin{array}{r}7 \\
14 \\
30 \\
60 \\
90\end{array}$ & $\begin{array}{l}111 \\
114 \\
123 \\
135 \\
149\end{array}$ & $\begin{array}{r}88 \\
90 \\
100 \\
111 \\
122\end{array}$ & $\begin{array}{r}78 \\
80 \\
90 \\
101 \\
110\end{array}$ & $\begin{array}{r}71 \\
73 \\
83 \\
93 \\
101\end{array}$ & $\begin{array}{l}64 \\
66 \\
76 \\
86 \\
92\end{array}$ \\
\hline
\end{tabular}

\begin{tabular}{|c|c|c|c|c|c|c|c|}
\hline $\begin{array}{l}\text { Discharg } \\
\text { was exce }\end{array}$ & $\begin{array}{l}\text { ratio } \\
\text { in } f\end{array}$ & $\begin{array}{l}\text { n tab } \\
\text { cubic } \\
\text { or ir }\end{array}$ & $\begin{array}{l}\text { le o } \\
\text { fee } \\
\text { dica }\end{array}$ & $\begin{array}{l}\text { dai. } \\
\text { per } \\
\text { ed p }\end{array}$ & $\begin{array}{l}\text { y } f 10 \\
\text { secon } \\
\text { rcent }\end{array}$ & of & $\begin{array}{l}\text { ich } \\
\text { ime }\end{array}$ \\
\hline Percent & 2 & 5 & 10 & 20 & 30 & 40 & 50 \\
\hline$f t^{3} / s$ & 950 & 580 & 415 & 308 & 255 & 222 & 199 \\
\hline Percent & 60 & 70 & 80 & 90 & 95 & 98 & 99.9 \\
\hline$f t^{3} / s$ & 177 & 159 & 139 & 120 & 109 & 98 & 78 \\
\hline
\end{tabular}

Accuracy. $--\mathrm{SE}_{7,2}=7$ percent, $\mathrm{SE}_{7,10}=9$ percent.

05377700 Cochrane Ditch at Cochrane, Wis.

Location. - - $\mathrm{SE} \frac{1}{4} \mathrm{SE} \frac{1}{4} \mathrm{sec} .8, \mathrm{~T} .20 \mathrm{~N} ., \mathrm{R} .12 \mathrm{~W}$. , Buffalo County, at country road bridge, 0.5 mi south of Cochrane.

Drainage area. $--8.87 \mathrm{mi}^{2}$. Tributary to.--Mississippi River.

Type of site.--Miscellaneous site.

Discharge measurements.--Aug. 9, 1972, $9.59 \mathrm{ft}_{3}^{3} / \mathrm{s} ;$ June $26,1973,8.72 \mathrm{ft}^{3} / \mathrm{s} ; \mathrm{Sept} .12,1973,7.58 \mathrm{ft} / \mathrm{s}$; Aug. 9, $1977,4.07 \mathrm{ft}^{3} / \mathrm{s}$; Sept. $14,1977,5.45 \mathrm{ft} 3 / \mathrm{s}$.

Low-flow frequency. $-Q_{7,2}=4.4 \mathrm{ft}^{3} / \mathrm{s}, Q_{7,10}=3.5 \mathrm{ft}^{3} / \mathrm{s}$.

Basis of estimate.--Correlated with Trempealeau River at Dodge using 5 discharge measurements.

Accuracy. $--\mathrm{SE}_{7,10}=19$ percent (basin average).

05378050 Waumandee Creek near Waumandee, Wis.

Location. - $-\mathrm{SW} \frac{1}{4} \mathrm{NW} \frac{1}{4} \mathrm{sec} .2$, T. 21 N., R. 11 W., Buffalo County, at bridge on private road, $1.6 \mathrm{mi}$ northeast of Waumandee.

Drainage area. --

Tributary to.--Mississippi River.

Type of site.--Miscellaneous site.

Discharge measurements.--Aug. $20,1976,18.5 \mathrm{ft}^{3} / \mathrm{s} ; \mathrm{Aug} .9,1977,13.8 \mathrm{ft} / \mathrm{s} ; \mathrm{Sept} .14,1977,13.6 \mathrm{ft} / \mathrm{s}$. Low-flow frequency. $-Q_{7,2}=12 \mathrm{ft}^{3} / \mathrm{s}, Q_{7,10}=7.8 \mathrm{ft}^{3} / \mathrm{s}$.

Basis of estimate.--Correlated with Trempealeau River at Dodge using 3 discharge measurements.

Accuracy. $--\mathrm{SE}_{7,10}=19$ percent (basin average). 
Table 1.--Low-flow characteristics for sites in the Trempealeau-Black River basin--Continued

05378060 Waumandee Creek at Waumandee, Wis.

Location. - $-\mathrm{SE}_{\frac{1}{4}} \mathrm{NW} \frac{1}{4} \mathrm{sec} .15, \mathrm{~T} .21 \mathrm{~N} ., \mathrm{R} .11 \mathrm{~W}$. , Buffalo County, at bridge on County Trunk E, 0.2 mi south of Waumandee.

Drainage area. $--56.0 \mathrm{mi}^{2}$. Tributary to.--Mississippi River.

Type of site.-Miscellaneous site.

Discharge measurement.--Aug. $11,1970,31.8 \mathrm{ft}^{3} / \mathrm{s}$.

Low-flow frequency. $--Q_{7,2}=22 \mathrm{ft}^{3} / \mathrm{s}, Q_{7,10}=17 \mathrm{ft}^{3} / \mathrm{s}$.

Basis of estimate.--Used regression equations 6 and 8 .

Accuracy. $--\mathrm{SE}_{7,2}=16$ percent, $\mathrm{SE}_{7,10}=22$ percent.

05378100 Little Waumandee Creek near Cream, Wis .

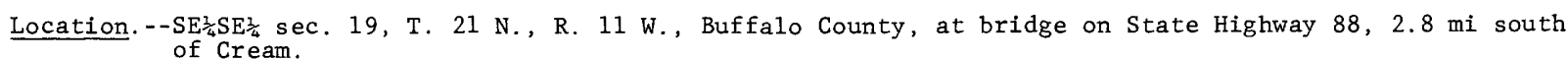

Drainage area. $--46.0 \mathrm{mi}^{2}$. Tributary to. --Waumandee Creek.

Type of site.--Low-flow partial-record station.

Minimum discharge measured. $--6.55 \mathrm{ft}^{3} / \mathrm{s}$, Aug. 19, 1964

Low-flow frequency. $-Q_{7,2}=12 \mathrm{ft}^{3} / \mathrm{s}, Q_{7,10}=7.0 \mathrm{ft}^{3} / \mathrm{s}$.

Basis of estimate.--Correlated with Trempealeau River at Dodge using 8 discharge measurements made during the period $1964-70$.

Accuracy. $--\mathrm{SE}_{7,2}=9$ percent, $\mathrm{SE}_{7,10}=15$ percent.

05378200 Eagle Creek near Fountain City, Wis.

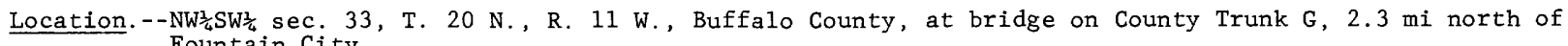
Fountain City.

Drainage area. $--26.8 \mathrm{mi}^{2}$. Tributary to.--Waumandee Creek.

Type of site.--Low-flow partial-record station.

Minimum discharge measured. $--4.02 \mathrm{ft}^{3} / \mathrm{s}$, Aug. 19, 1964.

Law-flow frequency. $-Q_{7,2}=5.5 \mathrm{ft}^{3} / \mathrm{s}, Q_{7,10}=4.1 \mathrm{ft} / \mathrm{s}$.

Basis of estimate.--Correlated with Trempealeau River at Dodge using 21 discharge measurements made during the period 1961-70.

Accuracy. $--\mathrm{SE}_{7,2}=6$ percent, $\mathrm{SE}_{7,10}=8$ percent.

05379180 Trempealeau River at Hixton, Wis.

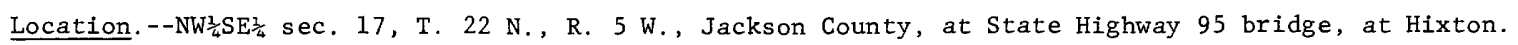

Drainage area. $--58.3 \mathrm{mi}^{2}$.

Tributary to.--Mississippi River.

Type of site.--Miscellaneous site.

Discharge measurements.--Aug. $10,1972,26.8 \mathrm{ft}_{3}^{3} / \mathrm{s} ;$ June $26,1973,54.2 \mathrm{ft} \mathrm{t}^{3} / \mathrm{s} ; \mathrm{Sept} .12,1973,39.5 \mathrm{ft} / \mathrm{s}$;

Aug. $21,1976,23.3 \mathrm{ft}^{3} / \mathrm{s}$; Sept. $15,1977,22.9 \mathrm{ft} / \mathrm{s}$.

Low-flow frequency. $-Q_{7,2}=19 \mathrm{ft}^{3} / \mathrm{s}, Q_{7,10}=14 \mathrm{ft}^{3} / \mathrm{s}$.

Basis of estimate.--Correlated with Trempealeau River at Dodge using 5 discharge measurements.

Accuracy. $--\mathrm{SE}_{7,10}=19$ percent (basin average). 
Table 1.--Low-flow characteristics for sites in the Trempealeau-Black River basin--Continued

05379200 Trempealeau River at Taylor, Wis.

Location. - $-\mathrm{NE}_{\frac{1}{4}} \mathrm{SE}_{\frac{1}{4}}^{\frac{1}{4} \mathrm{sec} .}$ 5, T. 21 N., R. 6 W., Jackson County, at County Trunk P, 0.4 mi north of Taylor.

Drainage area. $--110 \mathrm{mi}^{2}$.

Tributary to. --Mississippi River.

Type of site.--Low-flow partial-record station.

Minimum discharge measured. $--23.7 \mathrm{ft}^{3} / \mathrm{s}$, Aug. 18, 1964.

Low-flow frequency. $-Q_{7,2}=35 \mathrm{ft}^{3} / \mathrm{s}, Q_{7,10}=25 \mathrm{ft}^{3} / \mathrm{s}$.

Basis of estimate.--Correlated with Trempealeau River at Dodge using 13 discharge measurements made during the period 1964-77.

Accuracy. $--\mathrm{SE}_{7,2}=6$ percent, $\mathrm{SE}_{7,10}=8$ percent.

05379210 Trempealeau River at Blair, Wis.

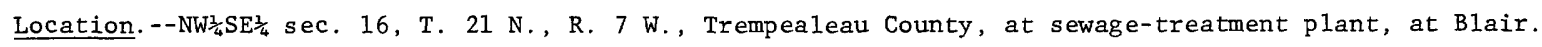

Drainage area. $--176 \mathrm{mi}^{2}$.

Tributary to.--Mississippi River.

Type of site.--Miscellaneous site.

Discharge measurements. --Aug. 10, 1972, $84.1 \mathrm{ft}^{3} / \mathrm{s} ;$ Sept. $12,1973,108 \mathrm{ft}^{3} / \mathrm{s} ; \mathrm{Jan} .9,1974,85.0 \mathrm{ft} / \mathrm{s}$; Aug. $20,1976,62.9 \mathrm{ft}^{3} / \mathrm{s}$; Sept. $14,1977,51.8 \mathrm{ft}^{3} / \mathrm{s}$.

Low-flow frequency. $-\mathrm{Q}_{7,2}=47 \mathrm{ft} / \mathrm{s}, \mathrm{Q}_{7,10}=34 \mathrm{ft} \mathrm{t}^{3} / \mathrm{s}$.

Basis of estimate.--Correlated with Trempealeau River at Dodge using 5 discharge measurements.

Accuracy. $--\mathrm{SE}_{7,10}=19$ percent (basin average).

05379212 Tappen Coulee at Blair, Wis.

Location. - - $\mathrm{SE}_{\frac{1}{4}} \mathrm{SE}_{\frac{1}{4}} \mathrm{sec} .16, \mathrm{~T} .21 \mathrm{~N} ., \mathrm{R}, 7 \mathrm{~W}$, Trempealeau County, at bridge on town road, at Blair.

Drainage area. $--4.44 \mathrm{mi}^{2}$. Tributary to. --Trempealeau River.

Type of site.--Miscellaneous site.

Discharge measurements.--Aug. 19, 1976, $0.80 \mathrm{ft}^{3} / \mathrm{s} ;$ Aug. $8,1977,0.55 \mathrm{ft}^{3} / \mathrm{s} ;$ Sept. $14,1977,0.61 \mathrm{ft} / \mathrm{s}$. Low-flow frequency. $-Q_{7,2}=0.49 \mathrm{ft}^{3} / \mathrm{s}, Q_{7,10}=0.30 \mathrm{ft}^{3} / \mathrm{s}$.

Basis of estimate. --Correlated with Trempealeau River at Dodge using 3 discharge measurements.

Accuracy. $--\mathrm{SE}_{7,10}=19$ percent (basin average).

05379220 Lyons Creek near Northfield, Wis .

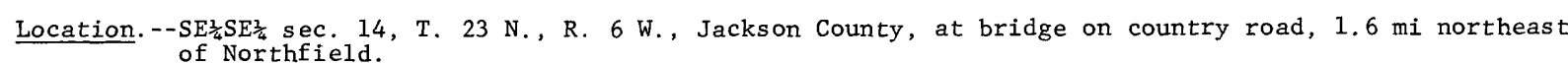
Drainage area. $--2.33 \mathrm{mi}^{2}$. Tributary to.--Pigeon Creek.

Type of site.--Miscellaneous site.

Discharge measurement.--Aug. 17, 1970,0.39 $\mathrm{ft}^{3} / \mathrm{s}$.

Low-flow frequency. $-Q_{7,2}=0.36 \mathrm{ft}^{3} / \mathrm{s}, Q_{7,10}=0.20 \mathrm{ft}^{3} / \mathrm{s}$.

Basis of estimate.--Used regression equations 6 and 8 .

Accuracy. $--\mathrm{SE}_{7,2}=16$ percent, $\mathrm{SE}_{7,10}=22$ percent. 
05379222 Pigeon Creek near Northfield, Wis.

Location. - - SW $\frac{1}{4} \mathrm{SE}^{\frac{2}{4}} \mathrm{sec} .14$, T. $23 \mathrm{~N}$., R. $6 \mathrm{~W}$, Jackson County, at bridge on country road, $1.4 \mathrm{mi}$ northeast of Northfield.

Drainage area. $--10.3 \mathrm{mi}^{2}$. Tributary to. --Trempealeau River.

Type of site.--Miscellaneous site.

Discharge measurement.--Aug. 17, $1970,7.12 \mathrm{ft}^{3} / \mathrm{s}$.

Low-flow frequency. $-Q_{7,2}=4.4 \mathrm{ft}^{3} / \mathrm{s}, Q_{7,10}=3.2 \mathrm{ft}^{3} / \mathrm{s}$.

Basis of estimate.--Used regression equations 6 and 8 .

Accuracy. $--\mathrm{SE}_{7,2}=16$ percent, $\mathrm{SE}_{7,10}=22$ percent.

05379224 Ellingson Coulee near Northfield, Wis.

Location. - - $-\mathrm{SE} \frac{1}{4} \mathrm{SW} \frac{1}{4} \mathrm{sec} .14$, T. $23 \mathrm{~N}$., R. $6 \mathrm{~W}$., Jackson County, at mouth, $1.4 \mathrm{mi}$ northeast of Northfield.

Drainage area. $--2.56 \mathrm{mi}^{2}$.

Tributary to.--Pigeon Creek.

Type of site.--Miscellaneous site.

Discharge measurement. - -Aug. 17, 1970, $0.66 \mathrm{ft}^{3} / \mathrm{s}$.

Low-flow frequency. $-Q_{7,2}=0.54 \mathrm{ft}^{3} / \mathrm{s}, Q_{7,10}=0.32 \mathrm{ft}^{3} / \mathrm{s}$.

Basis of estimate. - Used regression equations 6 and 8 .

Accuracy. $--\mathrm{SE}_{7,2}=16$ percent, $\mathrm{SE}_{7,10}=22$ percent.

05379226 Pigeon Creek at Northfield, Wis.

Location.--SW $\frac{1}{4} N W \frac{1}{4}$ sec. 22, T. 23 N., R. 6 W., Jackson County, at bridge on State Highway 27, at Northfield. Drainage area. $--17.0 \mathrm{mi}^{2}$. Tributary to. --Trempealeau River.

Type of site.--Miscellaneous site.

Discharge measurement.--Aug. $18,1970,9.96 \mathrm{ft}^{3} / \mathrm{s}$.

Low-flow frequency. $--_{7,2}=6.7 \mathrm{ft}^{3} / \mathrm{s}, Q_{7,10}=5.0 \mathrm{ft}^{3} / \mathrm{s}$.

Basis of estimate.--Used regression equations 6 and 8 .

Accuracy.- $-S E_{7,2}=16$ percent, $S E_{7,10}=22$ percent.

05379228 Sands Creek near York, Wis.

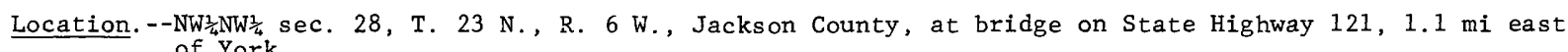
Drainage area. $--2.94 \mathrm{mi}^{2}$. Tributary to. --Pigeon Creek.

Type of site.--Miscellaneous site.

Discharge measurement. --Aug. $18,1970,0.68 \mathrm{ft}^{3} / \mathrm{s}$.

Low-flow frequency. $-Q_{7,2}=0.59 \mathrm{ft}^{3} / \mathrm{s}, Q_{7,10}=0.35 \mathrm{ft} / \mathrm{s}$.

Basis of estimate. - Used regression equations 6 and 8 .

Accuracy. $--S E_{7,2}=16$ percent, $S E_{7,10}=22$ percent. 
05379230 Beaver Creek near Northfield, Wis.

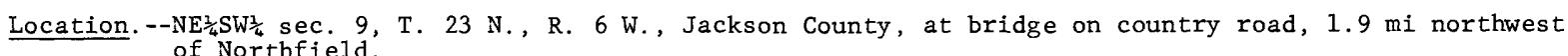
Drainage area. $--2.89 \mathrm{mi}^{2}$. Tributary to. --Pigeon Creek.

Type of site.--Miscellaneous site.

Discharge measurement.--Aug. $18,1970,1.23 \mathrm{ft}^{3} / \mathrm{s}$.

Low-flow frequency. $-Q_{7,2}=0.89 \mathrm{ft}^{3} / \mathrm{s}, Q_{7,10}=0.57 \mathrm{ft}^{3} / \mathrm{s}$.

Basis of estimate.--Used regression equations 6 and 8 .

Accuracy. $--\mathrm{SE}_{7,2}=16$ percent, $S E_{7,10}=22$ percent.

05379232 Beaver Creek at York, Wis. Location. - $-\mathrm{SW}_{\frac{1}{4} \mathrm{SW} \frac{3}{4} \mathrm{sec} .}$ 20, T. $23 \mathrm{~N} .$, R. $6 \mathrm{~W}$. , Jackson County, 0.1 mi upstream from mouth, $0.2 \mathrm{mi}$ northeast
of York.

Drainage area. $--6.63 \mathrm{mi}^{2}$.

Tributary to.--Pigeon Creek.

Type of site.--Miscellaneous site.

Discharge measurement.--Aug. $18,1970,2.92 \mathrm{ft}^{3} / \mathrm{s}$.

Low-flow frequency. $-Q_{7,2}=2.1 \mathrm{ft}^{3} / \mathrm{s}, Q_{7,10}=1.4 \mathrm{ft}^{3} / \mathrm{s}$.

Basis of estimate.--Used regression equations 6 and 8 .

Accuracy. $--\mathrm{SE}_{7,2}=16$ percent, $\mathrm{SE}_{7,10}=22$ percent.

05379234 Pigeon Creek at York, Wis.

Location. - - NW $\frac{1}{4} \mathrm{NW}_{4}^{\frac{1}{4}} \mathrm{sec} .29$, T. $23 \mathrm{~N} .$, R. $6 \mathrm{~W}$. , Jackson County, at bridge on County Trunk G, at York.

Drainage area. $-29.6 \mathrm{mi}^{2}$. Tributary to.--Trempealeau River.

Type of site.--Miscellaneous site.

Discharge measurement.--Aug. $18,1970,16.4 \mathrm{ft}^{3} / \mathrm{s}$.

Low-flow frequency. $-Q_{7,2}=11 \mathrm{ft}^{3} / \mathrm{s}, Q_{7,10}=8.7 \mathrm{ft}^{3} / \mathrm{s}$.

Basis of estimate.--Used regression equations 6 and 8 .

Accuracy. $--\mathrm{SE}_{7,2}=16$ percent, $\mathrm{SE}_{7,10}=22$ percent.

\section{Timber Creek at York, Wis.}

Location. - $-\mathrm{NE} \frac{1}{4} \mathrm{NE} \frac{1}{4}$ sec. $30, \mathrm{~T} .23 \mathrm{~N} ., \mathrm{R} .6 \mathrm{~W}$. , Jackson County, at mouth, at York.

Drainage area. $-4.78 \mathrm{mi}^{2}$. Tributary to.--Pigeon Creek.

Type of site.--Miscellaneous site.

Discharge measurement.--Aug. $18,1970,2.19 \mathrm{ft}^{3} / \mathrm{s}$.

Low-flow frequency. $-Q_{7,2}=1.6 \mathrm{ft}^{3} / \mathrm{s}, Q_{7,10}=1.0 \mathrm{ft}^{3} / \mathrm{s}$.

Basis of estimate.--Used regression equations 6 and 8 .

Accuracy. $--\mathrm{SE}_{7,2}=16$ percent, $\mathrm{SE}_{7,10}=22$ percent. 


\section{Schermerhorn Creek near York, Wis.}

Location. - - $\mathrm{NE}^{\frac{1}{4}} \mathrm{SE}_{\frac{1}{4}} \mathrm{sec} .32$, T. $23 \mathrm{~N} .$, R. 6 W. , Jackson County, at bridge on country road, $1.7 \mathrm{mi}$ southeast of York.

Drainage area. $--3.10 \mathrm{mi}^{2}$. Tributary to.--Pigeon Creek.

Type of site.--Miscellaneous site.

Discharge measurement. --Aug. $18,1970,0.47 \mathrm{ft}^{3} / \mathrm{s}$.

Low-flow frequency. $-Q_{7,2}=0.46 \mathrm{ft}^{3} / \mathrm{s}, Q_{7,10}=0.26 \mathrm{ft}^{3} / \mathrm{s}$.

Basis of estimate.--Used regression equations 6 and 8 .

Accuracy. $--\mathrm{SE}_{7,2}=16$ percent, $\mathrm{SE}_{7,10}=22$ percent.

05379240 Schermerhorn Creek near York, Wis .

Location. - - $\mathrm{SW}_{\frac{1}{4}} \mathrm{SEE}_{\frac{1}{4}} \mathrm{sec} .25$, T. $23 \mathrm{~N} .$, R. 7 W., Trempealeau County, at bridge on State Highway $121,1.5 \mathrm{mi}$ Drainage area. $--6.05 \mathrm{mi}^{2}$. Tributary to. --Pigeon Creek.

Type of site.--Miscellaneous site.

Discharge measurement. --Aug. $18,1970,1.46 \mathrm{ft}^{3} / \mathrm{s}$.

Low-flow frequency. $-Q_{7,2}=1.3 \mathrm{ft}^{3} / \mathrm{s}, Q_{7,10}=0.79 \mathrm{ft}^{3} / \mathrm{s}$.

Basis of estimate. --Used regression equations 6 and 8 .

Accuracy. $--\mathrm{SE}_{7,2}=16$ percent, $\mathrm{SE}_{7,10}=22$ percent.

05379242 Pigeon Creek near Pigeon Falls, Wis.

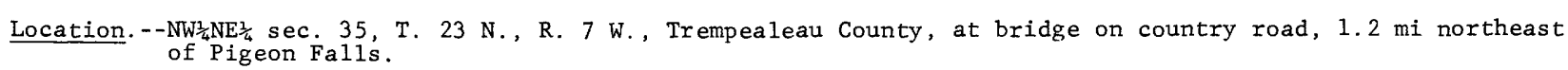

Drainage area. $--43.8 \mathrm{mi}^{2}$.

Tributary to. --Trempealeau River.

Type of site.--Miscellaneous site.

Discharge measurement.--Aug. 19, 1970, $23.9 \mathrm{ft}^{3} / \mathrm{s}$.

Low-flow frequency. $--_{7,2}=17 \mathrm{ft}^{3} / \mathrm{s}, Q_{7,10}=13 \mathrm{ft}^{3} / \mathrm{s}$.

Basis of estimate.--Used regression equations 6 and 8 .

Accuracy. $--\mathrm{SE}_{7,2}=16$ percent, $\mathrm{SE}_{7,10}=22$ percent.

05379244 Big Slough near Pigeon Falls, Wis.

Location. - - $\mathrm{NW}_{\frac{1}{4}} \mathrm{SE}^{\frac{1}{4}} \mathrm{sec}$, 1, T. $22 \mathrm{~N}$., R. $7 \mathrm{~W}$., Trempealeau County, just upstream from confluence with Tuff Coulee, 2.i mi southeast of Pigeon Falls.

Drainage area. $--4.74 \mathrm{mi}^{2}$.

Tributary to.--Pigeon Creek.

Type of site.--Miscellaneous site.

Discharge measurement.--Aug. 19, 1970, $0.94 \mathrm{ft}^{3} / \mathrm{s}$.

Low-flow frequency. $--_{7,2}=0.89 \mathrm{ft}^{3} / \mathrm{s}, Q_{7,10}=0.54 \mathrm{ft}^{3} / \mathrm{s}$.

Basis of estimate.--Used regression equations 6 and 8 .

Accuracy. $--\mathrm{SE}_{7,2}=16$ percent, $\mathrm{SE}_{7,10}=22$ percent. 
05379246 Tuff Coulee near Pigeon Falls, Wis.

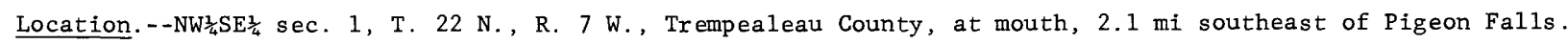
Drainage area. $--2.40 \mathrm{mi}^{2}$. Tributary to.--Big Slough.

Type of site.--Miscellaneous site.

Discharge measurement.--Aug. 19, 1970, $0.44 \mathrm{ft}^{3} / \mathrm{s}$.

Low-flow frequency. $-Q_{7,2}=0.42 \mathrm{ft}^{3} / \mathrm{s}, Q_{7,10}=0.24 \mathrm{ft}^{3} / \mathrm{s}$.

Basis of estimate.--Used regression equations 6 and 8 .

Accuracy. $--\mathrm{SE}_{7,2}=16$ percent, $\mathrm{SE}_{7,10}=22$ percent.

05379248 Big Slough near Pigeon Falls, Wis.

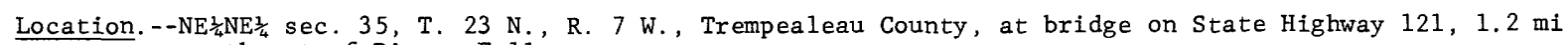
northeast of Pigeon Falls.

Drainage area. $--8.55 \mathrm{mi}^{2}$. Tributary to.--Pigeon Creek.

Type of site.--Miscellaneous site.

Discharge measurement. --Aug. 19, $1970,1.99 \mathrm{ft}^{3} / \mathrm{s}$.

Low-flow frequency. $-Q_{7,2}=1.8 \mathrm{ft}^{3} / \mathrm{s}, Q_{7,10}=1.2 \mathrm{ft}^{3} / \mathrm{s}$.

Basis of estimate.--Used regression equations 6 and 8 .

Accuracy. $--\mathrm{SE}_{7,2}=16$ percent, $\mathrm{SE}_{7,10^{n}}=22$ percent.

05379249 Pigeon Creek at Pigeon Falls, Wis.

Location.--SW $\frac{1}{4} \mathrm{SE} \frac{1}{4} \mathrm{sec} .34$, T. 23 N., R. 7 W., Trempealeau County, $300 \mathrm{ft}$ downstream from dam in Pigeon Falls Drainage area. $--58.4 \mathrm{mi}^{2}$. Tributary to.--Trempealeau River.

Type of site.--Miscellaneous site. Discharge measurements. --Aug. $10,1972,31.3 \mathrm{ft}^{3} / \mathrm{s} ;$ June $27,1973,77.1 \mathrm{ft}^{3} / \mathrm{s} ;$ Sept. $12,1973,44.1 \mathrm{ft} / \mathrm{s}$;

Low-flow frequency. $-Q_{7,2}=20 \mathrm{ft}^{3} / \mathrm{s}, Q_{7,10}=14 \mathrm{ft} / \mathrm{s}$.

Basis of estimate.--Correlated with Trempealeau River at Dodge using 5 discharge measurements.

Accuracy. - $-\mathrm{SE}_{7,10}=19$ percent (basin average).

\section{Pigeon Creek near Pigeon Falls, Wis.}

Location. --NW $\frac{1}{4} \mathrm{NW}_{\frac{1}{4}} \mathrm{sec}$. 9, T. $22 \mathrm{~N}$., R. $7 \mathrm{~W}$., Trempealeau County, just upstream from confluence with Moe Coulee, 2.3 mi southwest of Pigeon Falls.

Drainage area. $--65.7 \mathrm{mi}^{2}$.

Tributary to. --Trempealeau River.

Type of site.--Miscellaneous site.

Discharge measurement.--Aug. $19,1970,33.4 \mathrm{ft}^{3} / \mathrm{s}$.

Low-flow frequency. $-Q_{7,2}=25 \mathrm{ft}^{3} / \mathrm{s}, Q_{7,10}=20 \mathrm{ft}^{3} / \mathrm{s}$.

Basis of estimate.--Used regression equations 6 and 8 .

Accuracy. $-\mathrm{SE}_{7,2}=16$ percent, $\mathrm{SE}_{7,10}=22$ percent. 
05379257 Moe Coulee near Pigeon Falls, Wis.

Location.-- $\mathrm{NE}_{\frac{1}{4}} \mathrm{NE}^{\frac{1}{4}} \mathrm{sec} .8$, T. $22 \mathrm{~N}$., R. 7 W. , Trempealeau County, at mouth, $2.3 \mathrm{mi}$ southwest of Pigeon Falls. Drainage area. $--2.74 \mathrm{mi}^{2}$. Tributary to.--Pigeon Creek.

Type of site.--Miscellaneous site.

Discharge measurement. --Aug. 19, 1970, $0.75 \mathrm{ft}^{3} / \mathrm{s}$.

Low-flow frequency. $-Q_{7,2}=0.64 \mathrm{ft}^{3} / \mathrm{s}, Q_{7,10}=0.39 \mathrm{ft}^{3} / \mathrm{s}$.

Basis of estimate.--Used regression equations 6 and 8 .

Accuracy. $--\mathrm{SE}_{7,2}=16$ percent, $\mathrm{SE}_{7,10}=22$ percent.

05379260 Fitch Coulee near Pigeon Falls, Wis.

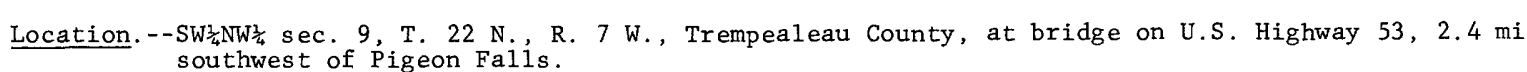
Drainage area. $--4.82 \mathrm{mi}^{2}$. Tributary to.--Pigeon Creek.

Type of site.--Miscellaneous site.

Discharge measurement.--Aug. $19,1970,1.33 \mathrm{ft}^{3} / \mathrm{s}$.

Low-flow frequency. $-Q_{7,2}=1.1 \mathrm{ft}^{3} / \mathrm{s}, Q_{7,10}=0.72 \mathrm{ft}^{3} / \mathrm{s}$.

Basis of estimate. --Used regression equations 6 and 8 .

Accuracy. $--\mathrm{SE}_{7,2}=16$ percent, $\mathrm{SE}_{7,10}=22$ percent.

05379263 Johnson Coulee near Whiteha11, Wis.

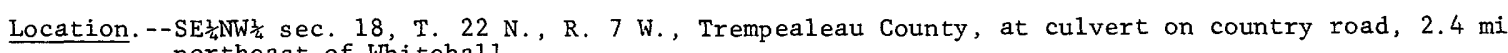
northeast of Whitehall.

Drainage area. $--2.10 \mathrm{mi}^{2}$. Tributary to.--Pigeon Creek.

Type of site.--Miscellaneous site.

Discharge measurement. --Aug. $19,1970,0.53 \mathrm{ft}^{3} / \mathrm{s}$.

Low-flow frequency. $-Q_{7,2}=0.46 \mathrm{ft}^{3} / \mathrm{s}, Q_{7,10}=0.27 \mathrm{ft}^{3} / \mathrm{s}$.

Basis of estimate.--Used regression equations 6 and 8 .

Accuracy. $--\mathrm{SE}_{7,2}=16$ percent, $\mathrm{SE}_{7,10}=22$ percent.

05379264 Pigeon Creek near Whitehall, Wis.

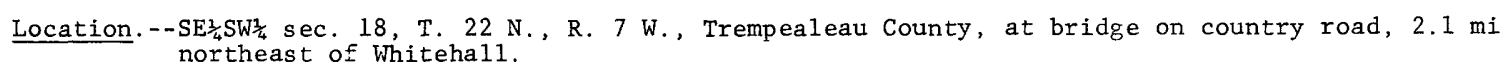
Drainage area. $--80.4 \mathrm{mi}^{2}$. Tributary to. --Trempealeau River.

Type of site.--Miscellaneous site.

Discharge measurement.--Aug. $12,1970,40.3 \mathrm{ft}^{3} / \mathrm{s}$.

Low-flow frequency. $-Q_{7,2}=29 \mathrm{ft}^{3} / \mathrm{s}, Q_{7,10}=23 \mathrm{ft}^{3} / \mathrm{s}$.

Basis of estimate.--Used regression equations 6 and 8 .

Accuracy. $--\mathrm{SE}_{7,2}=16$ percent, $\mathrm{SE}_{7,10}=22$ percent. 
Table 1.--Low-flow characteristics for sites in the Trempealeau-Black River basin--Continued

05379266 Pigeon Creek near Whitehall, Wis.

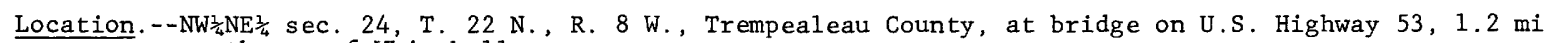
northeast of whitehall.

Drainage area. $--82.5 \mathrm{mi}^{2}$.

Tributary to. - - Trempealeau River.

Type of site.--Miscellaneous site.

Discharge measurement.--Aug. 19, 1970, $41.7 \mathrm{ft}^{3} / \mathrm{s}$.

Low-flow frequency. - $-Q_{7,2}=31 \mathrm{ft}^{3} / \mathrm{s}, Q_{7,10}=25 \mathrm{ft}^{3} / \mathrm{s}$.

Basis of estimate.--Used regression equations 6 and 8 .

Accuracy. $--\mathrm{SE}_{7,2}=16$ percent, $. \mathrm{SE}_{7,10}=22$ percent.

05379268 Fly Creek near B1air, Wis.

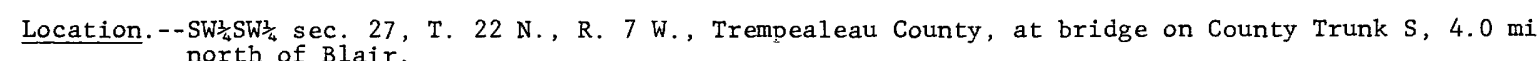

Drainage area $--2.99 \mathrm{mi}^{2}$

Type of site.--Miscellaneous site.

Discharge measurement. - - Aug. 19, 1970, $0.69 \mathrm{ft}^{3} / \mathrm{s}$.

Low-flow frequency. $-Q_{7,2}=0.62 \mathrm{ft}^{3} / \mathrm{s}, Q_{7,10}=0.37 \mathrm{ft}^{3} / \mathrm{s}$.

Basis of estimate.--Used regression equations 6 and 8 .

Accuracy. $--\mathrm{SE}_{7,2}=16$ percent, $\mathrm{SE}_{7,10}=22$ percent.

05379270 Fly Creek tributary near Blair, Wis.

Location. --SW $\frac{3}{4}$ SW $\frac{1}{4}$ sec. 27, T. 22 N., R. 7 W., Trempealeau County, at mouth, 4.0 mi north of Blair.

Drainage area. $--2.06 \mathrm{mi}^{2}$. Tributary to. --Fly Creek.

Type of site.--Miscellaneous site.

Discharge measurement.--Aug. 19, 1970,<0.1 ft $\mathrm{ft}^{3} / \mathrm{s}$ (estimate).

05379273 Fly Creek near Whiteha11, Wis.

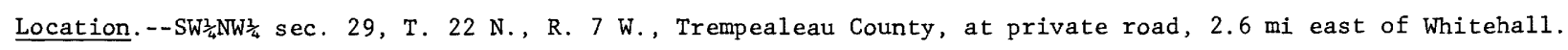
Drainage area. $--8.74 \mathrm{mi}^{2}$.

Tributary to.--Pigeon Creek.

Type of site.--Miscellaneous site.

Discharge measurement.--Aug. 19, 1970, $2.25 \mathrm{ft}^{3} / \mathrm{s}$.

Low-flow frequency. $-Q_{7,2}=2.0 \mathrm{ft}^{3} / \mathrm{s}, Q_{7,10}=1.3 \mathrm{ft}^{3} / \mathrm{s}$.

Basis of estimate.--Used regression equations 6 and 8 .

Accuracy. $--\mathrm{SE}_{7,2}=16$ percent, $\mathrm{SE}_{7,10}=22$ percent.

05379275 Fly Creek near Whitehal1, Wis.

Location. - - $-\mathrm{SW}_{\frac{1}{4}} \mathrm{NE}_{\frac{1}{4}} \mathrm{sec} .24$, T. $22 \mathrm{~N} .$, R. $8 \mathrm{~W}$., Trempealeau County, at bridge on country road, $1.3 \mathrm{mi}$ east of Whitehall.

Drainage area. $--10.2 \mathrm{mi}^{2}$. Tributary to. --Pigeon Creek.

Type of site.--Miscellaneous site.

Discharge measurement.--Aug. $19,1970,2.60 \mathrm{ft}^{3} / \mathrm{s}$.

Low-flow frequency. $-Q_{7,2}=2.5 \mathrm{ft}^{3} / \mathrm{s}, Q_{7,10}=1.5 \mathrm{ft}^{3} / \mathrm{s}$.

Basis of estimate.--Used regression equations 5 and 7.

Accuracy. $--\mathrm{SE}_{7,2}=10$ percent, $\mathrm{SE}_{7,10}=17$ percent. 
05379276 Trempealeau River at Whitehall, Wis.

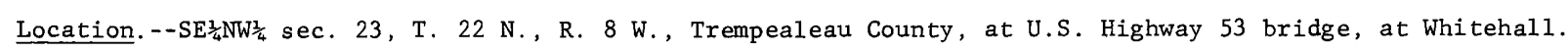
Drainage area. $--317 \mathrm{mi}^{2}$. Tributary to.--Mississippi River.

Type of site.--Miscellaneous site.

Discharge measurements. --Aug. 10, 1972, $159 \mathrm{ft}_{3}^{3} / \mathrm{s} ;$ June $27,1972,391 \mathrm{ft}^{3} / \mathrm{s} ;$ Sept. $12,1973,243 \mathrm{ft} / \mathrm{s}$; Aug. 20, 1976, $125 \mathrm{ft}^{3} / \mathrm{s}$; Sept. 14, $1977,105 \mathrm{ft}^{3} / \mathrm{s}$.

Low-flow frequency. $-Q_{7,2}=93 \mathrm{ft}^{3} / \mathrm{s}, Q_{7,10}=63 \mathrm{ft}^{3} / \mathrm{s}$.

Basis of estimate.--Correlated with Trempealeau River at Dodge using 5 discharge measurements.

Accuracy. - $-\mathrm{SE}_{7,10}=19$ percent (basin average).

05379278 Trempealeau River near Whitehall, Wis .

Location. - $-\mathrm{NE}^{\frac{1}{4} \mathrm{SE}} \frac{1}{4} \mathrm{sec} .20$, T. $22 \mathrm{~N} .$, R. 8 W., Trempealeau County, at bridge on State Highway $121,2.5 \mathrm{mi}$ Drainage area. $--330 \mathrm{mi}^{2}$. Tributary to. --Mississippi River.

Type of site.--Miscellaneous site.

Discharge measurement. --Aug. 12, $1970,139 \mathrm{ft}^{3} / \mathrm{s}$.

05379296 Elk Creek near Independence, Wis.

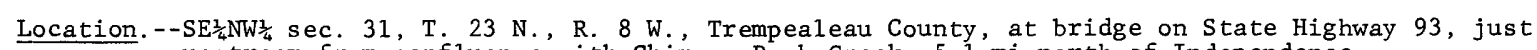
upstream from confluence with Chimney Rock Creek, $5.1 \mathrm{mi}$ north of Independence.

Drainage area. $--62.4 \mathrm{mi}^{2}$.

Tributary to. --Trempealeau River.

Type of site.--Miscellaneous site.

Discharge measurement.--Aug. 12, 1970, $22.1 \mathrm{ft}^{3} / \mathrm{s}$.

Low-flow frequency. $-Q_{7,2}=17 \mathrm{ft}^{3} / \mathrm{s}, Q_{7,10}=13 \mathrm{ft}^{3} / \mathrm{s}$.

Basis of estimate.--Used regression equations 6 and 8 .

Accuracy. $--\mathrm{SE}_{7,2}=16$ percent, $\mathrm{SE}_{7,10}=22$ percent.

05379299 Chimney Rock Creek near Independence, Wis. Location. $--\mathrm{SE}_{4} \mathrm{NW} / \frac{3}{4} \mathrm{sec} .31$, T. $23 \mathrm{~N}$., R. $8 \mathrm{~W}$. Trempealeau County, at bridge on State Highway 93 , at mouth,
$5.1 \mathrm{mi}$ north of Independence.

Drainage area. $--22.7 \mathrm{mi}^{2}$. Tributary to. --E1k Creek.

Type of site.--Miscellaneous site.

Discharge measurement. --Aug. 12, 1970, $9.74 \mathrm{ft}^{3} / \mathrm{s}$.

Low-flow frequency. $-Q_{7,2}=7.1 \mathrm{ft}^{3} / \mathrm{s}, Q_{7,10}=5.1 \mathrm{ft}^{3} / \mathrm{s}$.

Basis of estimate. --Used regression equations 6 and 8 .

Accuracy. $--\mathrm{SE}_{7,2}=16$ percent, $\mathrm{SE}_{7,10}=22$ percent.

05379300 Elk Creek at Elk Creek, Wis.

Location. - - $\mathrm{NE}_{\frac{1}{4}} \mathrm{SW}_{\frac{2}{4}} \mathrm{sec} .31$, T. $23 \mathrm{~N} ., \mathrm{R} .8 \mathrm{~W}$, at State Highway 93, $0.2 \mathrm{mi}$ north of Elk Creek.

Drainage area. $--90.1 \mathrm{mi}^{2}$. Tributary to. --Trempealeau River.

Type of site.--Low-flow partial-record station.

Minimum discharge measured. $--15.4 \mathrm{ft}^{3} / \mathrm{s}$, Aug. 14, 1964.

Low-flow frequency. $-Q_{7,2}=23 \mathrm{ft}^{3} / \mathrm{s}, Q_{7,10}=16 \mathrm{ft}^{3} / \mathrm{s}$.

Basis of estimate. --Correlated with Trempealeau River at Dodge using 10 discharge measurements made during the period 1964-77.

Accuracy. $-\mathrm{SE}_{7,2}=5$ percent, $\mathrm{SE}_{7,10}=8$ percent. 
05379320 E1k Creek at Independence, Wis.

Location.--SE $\frac{1}{4}$ NW $\frac{1}{4}$ sec. 25, T. 22 N., R. 9 W., Trempealeau County, at State Highways 93 and 121 bridge, in Independence.

Drainage area. $--101 \mathrm{mi}^{2}$. Tributary to. --Trempealeau River.

Type of site.-Miscellaneous site.

Discharge measurements.--Aug. $10,1972,53.0 \mathrm{ft}_{3}^{3} / \mathrm{s} ;$ June $27,1973,116 \mathrm{ft}^{3} / \mathrm{s} ; \mathrm{Sept} .12,1973,75.1 \mathrm{ft} / \mathrm{s}$; Low-flow frequency. $-Q_{7,2}=26 \mathrm{ft}^{3} / \mathrm{s}, Q_{7,10}=17 \mathrm{ft}^{3} / \mathrm{s}$.

Basis of estimate.--Correlated with Trempealeau River at Dodge using 5 discharge measurements. Accuracy. $--\mathrm{SE}_{7,10}=19$ percent (basin average).

05379400 Trempealeau River at Arcadia, Wis.

Location. --NW $\frac{1}{4} \mathrm{SW}_{\frac{1}{4}}$ sec. 32, T. 21 N., R. 9 W., at State Highways 93 and 95 , in Arcadia.

Drainage area. $--552 \mathrm{mi}^{2}$. Tributary to.--Mississippi River.

Type of site.--Gaging station.

Period of record.--July 1960 to September 1976.

Average discharge. - -16 years, $396 \mathrm{ft}^{3} / \mathrm{s}$.

Extremes.--Maximum discharge, 15,900 $\mathrm{ft}^{3} / \mathrm{s}$ Aug. 23, 1975; minimum discharge observed, $110 \mathrm{ft} / \mathrm{s}$ Aug. 8, 9, and 19, 1964 .

\begin{tabular}{|l|rrrrrr|}
\hline $\begin{array}{l}\text { Period } \\
\text { of con- } \\
\text { secutive } \\
\text { days }\end{array}$ & $\begin{array}{l}\text { Magnitude and frequency of annual low flow } \\
\text { Discharge, in cubic feet per second, for } \\
\text { indicated recurrence interval, in years } \\
\text { ind }\end{array}$ \\
\hline \multirow{3}{*}{14} & 2 & 5 & 10 & 20 & 50 & 100 \\
30 & 165 & 133 & 118 & 108 & 97 & 90 \\
60 & 170 & 137 & 122 & 112 & 100 & 94 \\
90 & 179 & 145 & 130 & 119 & 109 & 101 \\
& 194 & 158 & 142 & 130 & 119 & 111 \\
& 208 & 169 & 153 & 140 & 128 & 121 \\
\hline
\end{tabular}

\begin{tabular}{|l|rrrrrrr|}
\hline \multicolumn{7}{|c|}{ Duration table of daily flow } \\
Discharge, in cubic feet per second, which \\
was exceeded for indicated percent of time \\
\hline $\begin{array}{l}\text { Percent } \\
\mathrm{ft}^{3} / \mathrm{s}\end{array}$ & 2 & 5 & 10 & 20 & 30 & 40 & 50 \\
\hline Percent & 60 & 70 & 80 & 90 & 95 & 98 & 99.9 \\
$\mathrm{ft}^{3} / \mathrm{s}$ & 261 & 235 & 211 & 184 & 168 & 151 & 120 \\
\hline
\end{tabular}

Accuracy. $--\mathrm{SE}_{7,2}=4$ percent, $\mathrm{SE}_{7,10}=5$ percent.

Remarks. - The frequency analyses for the 7-, 14-, 30-, 60-, and 90-day low flows are based on the extension of records with 05379500 Trempealeau River at Dodge (1915-19, 1936-76 CY). Al1 correlation coefficients are greater than 0.99 .

05379407 Meyers Valley at Arcadia, Wis.

Location. - $-\mathrm{NW}_{\frac{1}{4}} \mathrm{NE}_{\frac{1}{4}}$ sec. 6, T. $20 \mathrm{~N}$., R. 9 W., Trempealeau County, at bridge on country road, 0.4 mi south of Arcadia.

Drainage area. $--5.57 \mathrm{mi}^{2}$.

Tributary to.--Trempealeau River.

Type of site.--Miscellaneous site.

Discharge measurements.--Aug. 19, 1976, $1.28 \mathrm{ft}^{3} / \mathrm{s} ;$ Aug. 8, 1977, $1.22 \mathrm{ft}{ }^{3} / \mathrm{s}$; Sept. 14, 1977, $1.28 \mathrm{ft} / \mathrm{s}$. Low-flow frequency. $-Q_{7,2}=1.2 \mathrm{ft}^{3} / \mathrm{s}, Q_{7,10}=0.76 \mathrm{ft}^{3} / \mathrm{s}$.

Basis of estimate.--Used regression equations 6 and 8 .

Accuracy. $--\mathrm{SE}_{7,2}=16$ percent, $\mathrm{SE}_{7,10}=22$ percent. 
05379500 Trempealeau River at Dodge, Wis.

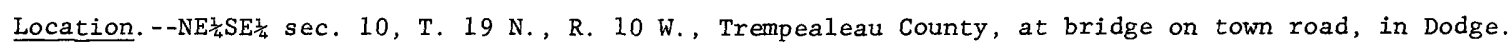
Drainage area. $--643 \mathrm{mi}^{2}$. Tributary to.--Mississippi River.

Type of site.--Gaging station.

Period of record.--December 1913 to September 1919, April 1934 to September 1976.

Average discharge. -47 years, $412 \mathrm{ft}^{3} / \mathrm{s}$.

Extremes.--Maximum discharge, $17,400 \mathrm{ft}^{3} / \mathrm{s}$ Apr. 4, 1956; minimum daily, $98 \mathrm{ft}^{3} / \mathrm{s} \mathrm{Jan} .10,1938$.

\begin{tabular}{|l|rrrrrr|}
\hline $\begin{array}{l}\text { Period } \\
\text { of con- } \\
\text { secutive } \\
\text { days }\end{array}$ & $\begin{array}{l}\text { Magnitude and frequency of annual low flow } \\
\text { Discharge, in cubic feet per second, for } \\
\text { indicated recurrence interval, in years }\end{array}$ \\
\hline & 2 & 5 & 10 & 20 & 50 & 100 \\
\cline { 2 - 7 } & 179 & 141 & 124 & 112 & 100 & 92 \\
7 & 185 & 146 & 129 & 117 & 104 & 96 \\
14 & 195 & 156 & 138 & 125 & 112 & 104 \\
30 & 212 & 170 & 151 & 138 & 125 & 117 \\
60 & 228 & 182 & 163 & 149 & 135 & 127 \\
90 & & &
\end{tabular}

\begin{tabular}{|l|rrrrrrr|}
\hline \multicolumn{7}{|c|}{ Duration table of daily flow } \\
Discharge, in cubic feet per second, which \\
was exceeded for indicated percent of time \\
\hline \begin{tabular}{c|rrrrrrr} 
Percent \\
$\mathrm{ft}^{3} / \mathrm{s}$
\end{tabular} & 2 & 5 & 10 & 20 & 30 & 40 & 50 \\
\hline $\begin{array}{l}\text { Percent } \\
\mathrm{ft}^{3} / \mathrm{s}\end{array}$ & 600 & 970 & 660 & 472 & 390 & 340 & 300 \\
\hline
\end{tabular}

Accuracy.--SE $7,2=4$ percent, $\mathrm{SE}_{7,10}=6$ percent.

05379550 Tamarack Creek near Galesville, Wis.

Location. - - $\mathrm{SE}_{\frac{1}{4}} \mathrm{NW}_{\frac{1}{4}} \mathrm{sec} .21, \mathrm{~T} .19 \mathrm{~N} ., \mathrm{R} .9 \mathrm{~W}$., Trempealeau County, at bridge on country road, $5.4 \mathrm{mi}$ northwest of Galesville.

Drainage area. $--34.8 \mathrm{mi}^{2}$.

Tributary to. --Trempealeau River.

Type of site.--Miscellaneous site.

Discharge measurement. --Aug. $11,1970,7.15 \mathrm{ft}^{3} / \mathrm{s}$.

Low-flow frequency. $-Q_{7,2}=6.6 \mathrm{ft}^{3} / \mathrm{s}, Q_{7,10}=4.5 \mathrm{ft}^{3} / \mathrm{s}$.

Basis of estimate. --Used regression equations 6 and 8 .

Accuracy. $--\mathrm{SE}_{7,2}=16$ percent, $\mathrm{SE}_{7,10}=22$ percent.

05379570 Tamarack Creek near Centerville, Wis.

Location. - SE $\frac{1}{4} \mathrm{SW} \frac{1}{4} \mathrm{sec} .36, \mathrm{~T} .19 \mathrm{~N} .$, R. $10 \mathrm{~W}$., Trempealeau County, at bridge on County Trunk G, $3.8 \mathrm{mi}$ west of Centervilie.

Drainage area. $--44.8 \mathrm{mi}^{2}$.

Tributary to. - -Trempealeau River.

Type of site.--Miscellaneous site.

Discharge measurement. --Aug. 11, 1970, $2.85 \mathrm{ft}^{3} / \mathrm{s}$. 
Location. - - $-\mathrm{SW}_{\frac{1}{4}} \mathrm{NE}^{\frac{1}{4}} \mathrm{sec} .12$, T. $18 \mathrm{~N} .$, R. $10 \mathrm{~W}$. Trempealeau County, at country road, 5.0 mi northwest of Trempealeau.

Drainage area. $--722 \mathrm{mi}^{2}$. Tributary to. --Mississippi River.

Type of site.--Gaging station.

Period of record.--October 1931 to September 1934 (seasonal records).

Average discharge. - -Not applicable.

Extremes.--Maximum discharge, 9,100 ft $\mathrm{ft}^{3} / \mathrm{s}$ Apr. 5, 1934; minimum, $150 \mathrm{ft}^{3} / \mathrm{s}$ Aug. 12-16, 1933, Aug. 29Sept. 2, 1933, June 23, 1934.

Low-flow frequency. - $-Q_{7,2}=190 \mathrm{ft}^{3} / \mathrm{s}, \mathrm{Q}_{7,10}=150 \mathrm{ft}^{3} / \mathrm{s}$.

Basis of estimate.--Correlated with Buffalo River near Tell using 11 daily mean discharges in the period 1932-34.

Accuracy. $--\mathrm{SE}_{7,2}=11$ percent, $\mathrm{SE}_{7,10}=13$ percent.

\section{Black River near Whittlesey, Wis .}

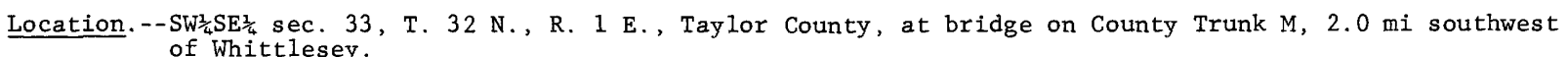
Drainage area. $--31.2 \mathrm{mi}^{2}$. Tributary to.--Mississippi River.

Type of site.--Miscellaneous site.

Discharge measurement.--Aug. 11, 1970, $2.48 \mathrm{ft}^{3} / \mathrm{s}$.

Low-flow frequency. $-Q_{7,2}=1.5 \mathrm{ft}^{3} / \mathrm{s}, Q_{7,10}=0.60 \mathrm{ft}^{3} / \mathrm{s}$.

Basis of estimate.--Used regression equations 9 and 10 .

Accuracy. $-\mathrm{SE}_{7,2}=45$ percent, $\mathrm{SE}_{7,10}=76$ percent.

05380805 Black River at Medford, Wis.

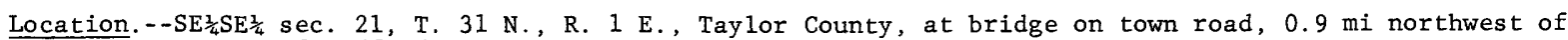
center of Medford.

Drainage area. $--42.3 \mathrm{mi}^{2}$.

Tributary to.--Mississippi River.

Type of site.--Miscellaneous site.

Discharge measurements.--0ct. 23, $1968,20.5 \mathrm{ft}^{3} / \mathrm{s}$; Aug. $26,1969,3.07 \mathrm{ft}^{3} / \mathrm{s}$.

Low-flow frequency.--Unable to determine low-flow characteristics, additional measurements required.

05380807 Black River at Medford, Wis.

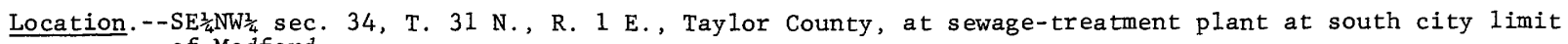
of Medford.

Drainage area. $--44.0 \mathrm{mi}^{2}$. Tributary to---Mississippi River.

Type of site.--Miscellaneous site.

Minimum discharge measured. $--1.41 \mathrm{ft}^{3} / \mathrm{s}$, Aug. $31,1976$.

Low-flow frequency. $-Q_{7,2}=3.4 \mathrm{ft}^{3} / \mathrm{s}, Q_{7,10}=0.81 \mathrm{ft}^{3} / \mathrm{s}$.

Basis of estimate.--Correlated with Black River at Neillsville using 11 discharge measurements made during the period 1968-76.

Accuracy. $--\mathrm{SE}_{7,2}=42$ percent, $\mathrm{SE}_{7,10}=47$ percent. 
05380817 East Branch Little Black River near Medford, Wis.

Location. - $-\mathrm{NE} \frac{1}{4} \mathrm{SE} \frac{1}{4} \mathrm{sec} .29$, T. 31 N., R. 2 E., Taylor County, at bridge on State Highway 64 , 4.6 mi east of Medford.

Drainage area. --

Tributary to.--Little Black River.

Type of site.--Miscellaneous site.

Discharge measurement.--May 24, 1963, $9.08 \mathrm{ft}^{3} / \mathrm{s}$.

05380820 Little Black River near Medford, Wis.

Location.--SW $\frac{1}{4} \mathrm{sec} .1$, T. 30 N., R. 1 E., Taylor County, at bridge on State Highway 13 , 2.1 mi south of Drainage area.--58 $\mathrm{mi}^{2}$ (approximate). Tributary to.--Black River.

Type of site.--Low-flow partial-record station.

Minimum discharge measured. $-0.04 \mathrm{ft}^{3} / \mathrm{s}$, Aug. 5, 1964 .

Low-flow frequency. $--Q_{7,2}=0.26 \mathrm{ft}^{3} / \mathrm{s}, Q_{7,10}=0.01 \mathrm{ft}^{3} / \mathrm{s}$.

Basis of estimate.--Correlated with Black River at Nei11sville using 11 discharge measurements made during the period 1962-69.

Accuracy. $--\mathrm{SE}_{7,2}=24$ percent, $\mathrm{SE}_{7,10}=66$ percent.

05380825 Black River near Medford, Wis.

Location. - -SW $\frac{1}{4} \mathrm{SW} \frac{1}{4} \mathrm{sec} .2$, T. 30 N., R. 1 E., Taylor County, on country road, $2.0 \mathrm{mi}$ south of Medford.

Drainage area. $--112 \mathrm{mi}^{2}$.

Tributary to.--Mississippi River.

Type of site.--Miscellaneous site.

Discharge measurement.--Aug. $11,1970,6.54 \mathrm{ft}^{3} / \mathrm{s}$.

Low-f1ow frequency. $-Q_{7,2}=4.4 \mathrm{ft}^{3} / \mathrm{s}, Q_{7,10}=1.5 \mathrm{ft}^{3} / \mathrm{s}$.

Basis of estimate.--Used regression equations 9 and 10 .

Accuracy. $--\mathrm{SE}_{7,2}=45$ percent, $\mathrm{SE}_{7,10}=76$ percent.

05380830 Black River near Medford, Wis.

Location.-- $\begin{gathered}\text { SW } \frac{1}{4} \mathrm{SE}_{\frac{1}{4}} \mathrm{sec} . \\ \text { Medford. }\end{gathered}$ Drainage area. $--131 \mathrm{mi}^{2}$. Tributary to.--Mississippi River.

Type of site.--Miscellaneous site.

Discharge measurements.--Oct. 23, 1968, $34.2 \mathrm{ft}^{3} / \mathrm{s}$; Aug. 26, 1969, 6.06 $\mathrm{ft}^{3} / \mathrm{s}$.

Low-flow frequency. $-\mathrm{Q}_{7,2}=5.1 \mathrm{ft}^{3} / \mathrm{s}, Q_{7,10}=1.8 \mathrm{ft}^{3} / \mathrm{s}$.

Basis of estimate. - Used equations 9 and 10 .

Accuracy. $--\mathrm{SE}_{7,2}=45$ percent, $\mathrm{SE}_{7,10}=76$ percent.

05380850 Black River near Lublin, Wis.

Location. - - NE $\frac{1}{4} \mathrm{NW}_{\frac{1}{4}} \mathrm{sec} .1, \mathrm{~T} .30 \mathrm{~N}$, , R. 2 W., Taylor County, at bridge on State Highway 64 , 8.3 mi northeast of Lublin.

Drainage area. $--195 \mathrm{mi}^{2}$.

Tributary to.--Mississippi River.

Type of site.--Miscellaneous site.

Discharge measurements.--Oct. 23, 1968, 61.5 ft $\mathrm{ft}^{3} / \mathrm{s}$; Aug. 26, 1969, $12.2 \mathrm{ft}^{3} / \mathrm{s}$. 
05380870 Pine Creek near Medford, Wis.

Location.--SW $\frac{1}{4} \mathrm{SW}_{4}^{\frac{1}{4}} \mathrm{sec} .19$, T. $30 \mathrm{~N} .$, R. $1 \mathrm{~W}$. , Taylor County, at bridge on County Trunk DD, $11.8 \mathrm{mi}$ southwest of Medford.

Drainage area. $--34.3 \mathrm{mi}^{2}$.

Tributary to. --Black River.

Type of site.--Low-flow partial-record station.

Minimum discharge measured.--0.20 ft $\mathrm{ft}^{3} / \mathrm{s}$, Aug. 5, 1964.

Low-flow frequency. $-Q_{7,2}=0.58 \mathrm{ft}^{3} / \mathrm{s}, Q_{7,10}=0.12 \mathrm{ft}^{3} / \mathrm{s}$.

Basis of estimate.--Correlated with Black River at Neillsville using 14 discharge measurements made during the period 1962-70.

Accuracy.-- $-\mathrm{SE}_{7,2}=13$ percent, $\mathrm{SE}_{7,10}=32$ percent.

05380879 McKenzie Creek near Lublin, Wis.

Location. - $-\mathrm{SW}_{\frac{1}{4}} \mathrm{SE}_{\frac{1}{4}} \mathrm{sec} .20$, T. $30 \mathrm{~N}$, R. 2 W., Taylor County, at bridge on country road, $4.0 \mathrm{mi}$ east of Lublin. Drainage area. $--22.6 \mathrm{mi}^{2}$. Tributary to. --Black River.

Type of site.--Miscellaneous site.

Discharge measurement.--Aug. $11,1970,0.59 \mathrm{ft}^{3} / \mathrm{s}$.

Low-flow frequency.--Unable to define low-flow characteristics, additional discharge measurements are required.

05380880 McKenzie Creek near Lublin, Wis.

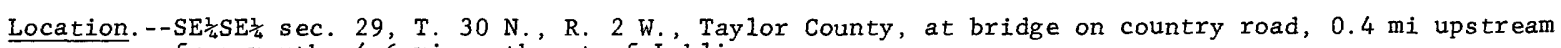
from mouth, $4.6 \mathrm{mi}$ southeast of Lublin.

Drainage area. $--23.5 \mathrm{mi}^{2}$. Tributary to. --Black River.

Type of site.--Miscellaneous site.

Discharge measurements.--Oct. 24, 1968, $7.00 \mathrm{ft}^{3} / \mathrm{s} ;$ Aug. $26,1969,0.46 \mathrm{ft}^{3} / \mathrm{s}$.

Low-flow frequency. - $-Q_{7,2}=0.34 \mathrm{ft}^{3} / \mathrm{s}, Q_{7,10}=0.03 \mathrm{ft}^{3} / \mathrm{s}$.

Basis of estimate.--Correlated with Black River near Neillsville using 3 discharge measurements.

Accuracy. $--\mathrm{SE}_{7,10}=68$ percent.

05380885 Black River near Withee, Wis.

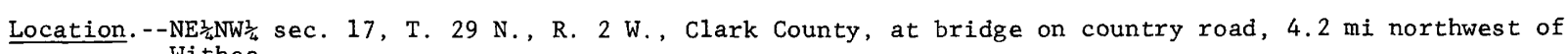
Withee.

Drainage area. $--302 \mathrm{mi}^{2}$.

Tributary to. --Mississippi River.

Type of site.--Miscellaneous site.

Discharge measurements.--0ct. $24,1968,92.5 \mathrm{ft}^{3} / \mathrm{s} ;$ Aug. $27,1969,15.1 \mathrm{ft}^{3} / \mathrm{s}$

05380886 Black River near Withee, Wis.

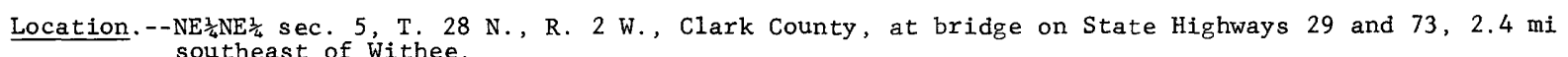

Drainage area. $--316 \mathrm{mi}^{2}$.

Tributary to. --Mississippi River.

Type of site.--Miscellaneous site.

Discharge measurement.--Aug. 12, $1970,17.6 \mathrm{ft}^{3} / \mathrm{s}$. 
05380887 East Fork Poplar River near Curtiss, Wis.

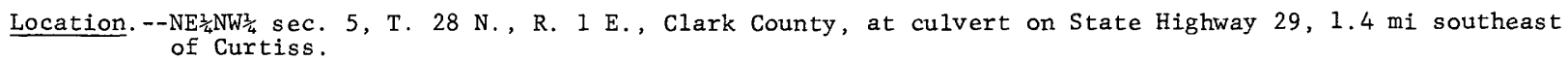

Drainage area. $--1.16 \mathrm{mi}^{2}$. Tributary to.--South Fork Poplar River.

Type of site.--Miscellaneous site.

Discharge measurements. --Sept. $30,1976,0 \mathrm{ft}^{3} / \mathrm{s} ; 0 \mathrm{Ot} .18,1976,0 \mathrm{ft}^{3} / \mathrm{s} ;$ Nov. 10, 1976, $0 \mathrm{ft}^{3} / \mathrm{s}$;

. $1,1976,0 \mathrm{ft}^{3} / \mathrm{s}$.

Low-flow frequency. $-Q_{7,2}=0.00 \mathrm{ft}^{3} / \mathrm{s}, Q_{7,10}=0.00 \mathrm{ft}^{3} / \mathrm{s}$.

Basis of estimate.--Correlated with Black River at Neillsville using 4 discharge measurements.

Accuracy. --Not applicable.

05380889 South Fork Poplar River near Riplinger, Wis.

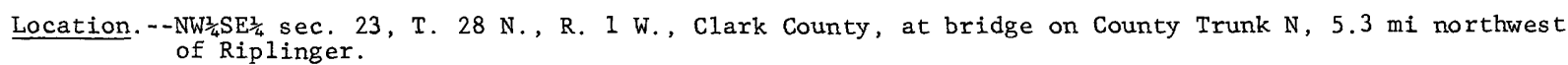
Drainage area. $--49.2 \mathrm{mi}^{2}$. Tributary to. --Black River.

Type of site.--Miscellaneous site.

Discharge measurement. --Aug. $11,1970,0.90 \mathrm{ft}^{3} / \mathrm{s}$.

Low-flow frequency. $-Q_{7,2}=0.56 \mathrm{ft}^{3} / \mathrm{s}, Q_{7,10}=0.16 \mathrm{ft}^{3} / \mathrm{s}$.

Basis of estimate.--Used regression equations 9 and 10 .

Accuracy. $--\mathrm{SE}_{7,2}=45$ percent, $\mathrm{SE}_{7,10}=76$ percent

05380890 South Fork Poplar River near Owen, Wis.

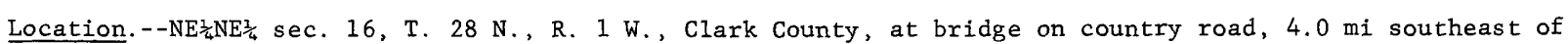
Owen.

Drainage area. $--58.1 \mathrm{mi}^{2}$. Tributary to. --B1ack River.

Type of site.--Miscellaneous site.

Discharge measurements.--Oct. 24, 1968, $6.62 \mathrm{ft}^{3} / \mathrm{s} ;$ Aug. $27,1969,0.94 \mathrm{ft}^{3} / \mathrm{s}$.

Low-flow frequency. $-\mathrm{Q}_{7,2}=0.75 \mathrm{ft}^{3} / \mathrm{s}, Q_{7,10}=0.21 \mathrm{ft}^{3} / \mathrm{s}$.

Basis of estimate.--Used regression equations 9 and 10.

Accuracy. $--\mathrm{SE}_{7,2}=45$ percent, $\mathrm{SE}_{7,10}=76$ percent.

05380891 North Fork Poplar River at Dorchester, Wis.

Location. - - $\mathrm{NE}_{\frac{1}{4}} \mathrm{NE}_{\frac{1}{4}}^{\frac{1}{4}} \mathrm{sec} .14$, T. $29 \mathrm{~N} ., \mathrm{R} .1 \mathrm{E}$, Clark County, at sewage-treatment plant, at Dorchester.

Drainage area. $--2.37 \mathrm{mi}^{2}$.

Tributary to.--Poplar River.

Type of site. - Miscellaneous site.

Minimum discharge measured. $--<0.01 \mathrm{ft}^{3} / \mathrm{s}$, Oct. 16, 1973, July 29, 1974, Sept. 5, 1974, Aug. $18,1975$.

Low-flow frequency. $-Q_{7,2}=0.00 \mathrm{ft}^{3} / \mathrm{s}, Q_{7,10}=0.00 \mathrm{ft}^{3} / \mathrm{s}$.

Basis of estimate.--Correlated with Black River at Neillsville using 6 discharge measurements made during the period 1973-75.

Accuracy. --Not applicable. 
05380893 North Fork Poplar River tributary at Curtiss, Wis.

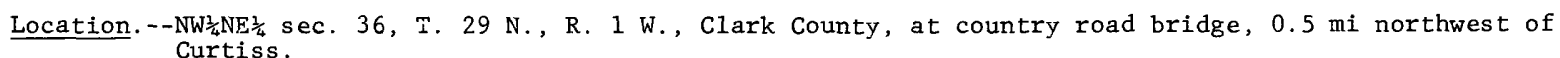

Drainage area. $-0.66 \mathrm{mi}^{2}$.

Tributary to.--North Fork Poplar River.

Type of site.--Miscellaneous site.

Minimum discharge measured. $-0.00 \mathrm{ft}^{3} / \mathrm{s}$, June 30, 1973, Aug. 7, 1973, 0ct. 6, 1973, July 30, 1974, Sept. 5, 1974, and Aug. 18, 1975 .

Low-flow frequency. $-Q_{7,2}=0.00 \mathrm{ft}^{3} / \mathrm{s}, Q_{7,10}=0.00 \mathrm{ft}^{3} / \mathrm{s}$.

Basis of estimate.--Correlated with Black River near Neillsville using 6 discharge measurements.

Accuracy. - - Not applicable.

05380895 North Fork Poplar River near Owen, Wis.

Location. - $-\mathrm{NE} \frac{1}{4} \mathrm{NE} \frac{1}{4} \mathrm{sec} .5$, T. $28 \mathrm{~N}$, R. 1 W., Clark County, at bridge on State Highway 29 , 2.1 mi east of Owen. Drainage area. $--55.6 \mathrm{mi}^{2}$. Tributary to.--Poplar River.

Type of site.--Miscellaneous site.

Minimum discharge measured. $--0.10 \mathrm{ft}^{3} / \mathrm{s}$, Aug. 18, 1975 .

Low-flow frequency. $--Q_{7,2}=0.49 \mathrm{ft}^{3} / \mathrm{s}, Q_{7,10}=0.07 \mathrm{ft}^{3} / \mathrm{s}$.

Basis of estimate.--Correlated with Black River at Neillsville using 9 discharge measurements made during the period $1968-76$.

Accuracy. $--\mathrm{SE}_{7,2}=26$ percent, $S E_{7,10}=59$ percent.

05380897 Poplar River at Owen, Wis.

Location. - $-\mathrm{NE}_{\frac{1}{4}} \mathrm{NW}_{\frac{1}{4}} \mathrm{sec} .1, \mathrm{~T} .28 \mathrm{~N} ., \mathrm{R} .2 \mathrm{~W} ., \mathrm{Clark}$ County, at sewage-treatment plant, at Owen.

Drainage area. $--145 \mathrm{mi}^{2}$.

Tributary to.--Black River.

Type of site.--Miscellaneous site.

Minimum discharge measured.--0.21 ft $\mathrm{f}^{3} / \mathrm{s}$, Sept. 5, 1974.

Low-flow frequency. $-Q_{7,2}=1.5 \mathrm{ft}^{3} / \mathrm{s}, Q_{7,10}=0.28 \mathrm{ft}^{3} / \mathrm{s}$.

Basis of estimate.--Correlated with Black River at Neillsville using 7 discharge measurements made during the period 1973-76.

Accuracy. $--\mathrm{SE}_{7,2}=42$ percent, $\mathrm{SE}_{7,10}=77$ percent.

05380900 Poplar River near Owen, Wis.

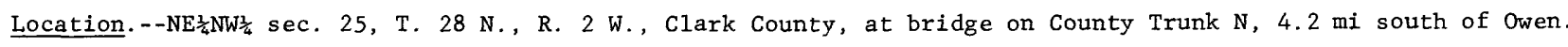
Drainage area. $--157 \mathrm{mi}^{2}$. Tributary to.--Black River.

Type of site.--Low-flow partial-record station.

Minimum discharge measured. $-1.1 \mathrm{ft}^{3} / \mathrm{s}$, Aug. 15, 1964 .

Low-flow frequency. $-\mathrm{Q}_{7,2}=3.7 \mathrm{ft}^{3} / \mathrm{s}, \mathrm{Q}_{7,10}=1.2 \mathrm{ft}^{3} / \mathrm{s}$. Basis of estimate.--Correlated with B1ack River at Neillsville using 20 discharge measurements and daily

Accuracy.- $-\mathrm{SE}_{7,2}=22$ percent, $\mathrm{SE}_{7,10}=30$ percent.

Remarks. --Operated as a continuous-record gaging station during open-water periods in $1964-66$ water years. 
05380915 Black River at Greenwood, Wis.

Location. - - NW $\frac{1}{4} \mathrm{NE} \frac{1}{4} \mathrm{sec} .3$, T. 26 N., R. 2 W., Clark County, at bridge on County Trunk G, at Greenwood.

Drainage area. $--524 \mathrm{mi}^{2}$. Tributary to. --Mississippi River.

Type of site.--Miscellaneous site.

Discharge measurements.--0ct. 25, 1968, $128 \mathrm{ft}^{3} / \mathrm{s}$; Aug. $28,1969,21.6 \mathrm{ft}^{3} / \mathrm{s}$; Aug. 12, $1970,39.4 \mathrm{ft}^{3} / \mathrm{s}$. Low-flow frequency. $-Q_{7,2}=23 \mathrm{ft}^{3} / \mathrm{s}, Q_{7,10}=5.8 \mathrm{ft}^{3} / \mathrm{s}$.

Basis of estimate.--Correlated with Black River at Neillsville using 3 discharge measurements.

Accuracy.- $-\mathrm{SE}_{7,10}=68$ percent (basin average).

05380935 Nelson Creek near Greenwood, Wis.

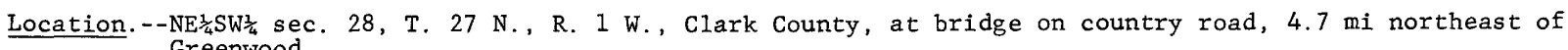
Greenwood.

Drainage area. $--28.1 \mathrm{mi}^{2}$. Tributary to. --Rock Creek.

Type of site.--Miscellaneous site.

Discharge measurements.--Oct. 25, 1968, $2.39 \mathrm{ft}^{3} / \mathrm{s} ;$ Aug. $28,1969,0.51 \mathrm{ft}^{3} / \mathrm{s}$.

Low-flow frequency. $-Q_{7,2}=0.38 \mathrm{ft}^{3} / \mathrm{s}, Q_{7,10}=0.11 \mathrm{ft}^{3} / \mathrm{s}$.

Basis of estimate.- -Used regression equations 9 and 10 .

Accuracy. $--\mathrm{SE}_{7,2}=45$ percent, $\mathrm{SE}_{7,10}=76$ percent.

05380945 Bear Creek at Loya1, Wis.

Location.--SW $\frac{1}{4} \mathrm{SW}_{\frac{1}{4}}$ sec. 10, T. 26 N., R. 1 W., Clark County, at bridge on County Trunk K, upstream from sewage-treatment plant, at Loyal.

Drainage area. $--2.97 \mathrm{mi}^{2}$. $\quad$ Tributary to.--Rock Creek.

Type of site.--Miscellaneous site.

Minimum discharge measured. $--0 \mathrm{ft}^{3} / \mathrm{s}$ (ponded), Sept. 5, 1974, Aug. 19, 1975.

Low-flow frequency. $-Q_{7,2}=0.08 \mathrm{ft}^{3} / \mathrm{s}, Q_{7,10}=0.03 \mathrm{ft}^{3} / \mathrm{s}$.

Basis of estimate.--Correlated with Black River at Neillsville using 8 discharge measurement made during the period 1972-76.

Accuracy. $--\mathrm{SE}_{7,10}=68$ percent (basin average).

05380950 Rock Creek at Greenwood, Wis.

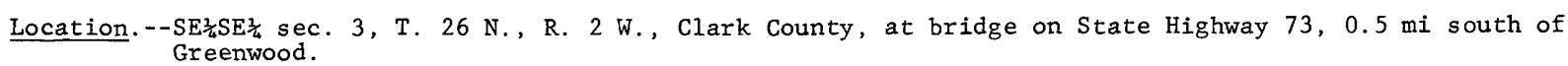
Drainage area. $--78.4 \mathrm{mi}^{2}$. Tributary to.--Black River.

Type of site.--Miscellaneous site.

Minimum discharge measured. $--0.16 \mathrm{ft}^{3} / \mathrm{s}$, Aug. 31, 1976

Low-flow frequency. $-Q_{7,2}=0.88 \mathrm{ft}^{3} / \mathrm{s}, Q_{7,10}=0.12 \mathrm{ft}^{3} / \mathrm{s}$.

Basis of estimate.--Correlated with Black River near Neillsville using 11 discharge measurements made during the period 1968-76.

Accuracy. $--\mathrm{SE}_{7,2}=20$ percent, $\mathrm{SE}_{7,10}=47$ percent. 
05380965 Cawley Creek near Loyal, Wis.

Location. - - $\mathrm{SE}_{\frac{1}{4}} \mathrm{SE}_{\frac{1}{4}} \mathrm{sec} .24$, T. 26 N., R. 2 W., Clark County, at bridge on town road, 3.7 mi southwest of Loyal. Drainage area. $--5.14 \mathrm{mi}^{2}$. Tributary to. --B1ack River.

Type of site.--Miscellaneous site.

Discharge measurements.--Sept. $5,1974,0.20 \mathrm{ft}^{3} / \mathrm{s}$; Aug. 19, 1975, $0.15 \mathrm{ft}^{3} / \mathrm{s} ;$ Aug. $23,1977,0.12 \mathrm{ft} / \mathrm{s}$. Low-flow frequency. $-Q_{7,2}=0.11 \mathrm{ft}^{3} / \mathrm{s}, Q_{7,10}=0.02 \mathrm{ft}^{3} / \mathrm{s}$.

Basis of estimate.--Correlated with Black River at Neillsville using 3 discharge measurements.

Accuracy. $--\mathrm{SE}_{7,10}=68$ percent (basin average).

05380970 Cawley Creek near Neillsville, Wis .

Location. - - SW $\mathrm{sec}$. 25, T. $25 \mathrm{~N}$., R. 2 W., Clark County, at bridge on State Highway $73,3.7 \mathrm{mi}$ north of Drainage area. $--38.6 \mathrm{mi}^{2}$. Tributary to. --B1ack River.

Type of site.--Low-flow partial-record station.

Minimum discharge measured. $--0.08 \mathrm{ft}^{3} / \mathrm{s}$, Aug. 5, 1964.

Low-flow frequency. $-Q_{7,2}=0.53 \mathrm{ft}^{3} / \mathrm{s}, Q_{7,10}=0.09 \mathrm{ft}^{3} / \mathrm{s}$.

Basis of estimate. --Correlated with Black River near Neillsville using 16 discharge measurements made during the period 1962-70.

Accuracy. $--\mathrm{SE}_{7,2}=20$ percent, $\mathrm{SE}_{7,10}=42$ percent.

05380980 North Branch O'Neill Creek near Neillsville, Wis.

Location. - $-\mathrm{NE}_{4}^{\frac{1}{4}} \mathrm{SW}_{4}^{\frac{1}{4}} \mathrm{sec} .7$, T. $24 \mathrm{~N}$, , R. $1 \mathrm{~W}$., Clark County, at bridge on country road, 2.4 mi northeast of of Neillsville.

Drainage area. $--34.5 \mathrm{mi}^{2}$.

Tributary to.--Black River.

Type of site.--Miscellaneous site.

Discharge measurements. - - Oct. 25, 1968, $3.23 \mathrm{ft}^{3} / \mathrm{s} ;$ Aug. $28,1969,0.32 \mathrm{ft}^{3} / \mathrm{s}$.

Low-flow frequency. $-Q_{7,2}=0.38 \mathrm{ft}^{3} / \mathrm{s}, Q_{7,10}=0.10 \mathrm{ft}^{3} / \mathrm{s}$.

Basis of estimate.--Used regression equations 9 and 10 .

Accuracy. $--\mathrm{SE}_{7,2}=45$ percent, $\mathrm{SE}_{7,10}=76$ percent.

05380985 South Branch O'Nei11 Creek at Granton, Wis.

Location. - $-\mathrm{NW}_{\frac{1}{4}} \mathrm{SE}_{\frac{1}{4}}^{\frac{1}{4}} \mathrm{sec} .2$, T. $24 \mathrm{~N}$, , R. $1 \mathrm{~W} .$, Clark County, at sewage-treatment p1ant, $0.2 \mathrm{mi}$ downstream from County Trunk $\mathrm{K}$ bridge, at Granton.

Drainage area. $--16.9 \mathrm{mi}^{2}$.

Tributary to. - - $^{\prime}$ Neil1 Creek.

Type of site.--Miscellaneous site.

Minimum discharge measured. $--0.17 \mathrm{ft}^{3} / \mathrm{s}$, Aug. 31, 1976

Low-flow frequency. $-Q_{7,2}=0.30 \mathrm{ft}^{3} / \mathrm{s}, Q_{7,10}=0.07 \mathrm{ft}^{3} / \mathrm{s}$.

Basis of estimate.--Correlated with Black River at Neillsville using 10 discharge measurements made during the period 1972-77.

Accuracy. $--\mathrm{SE}_{7,2}=19$ percent, $\mathrm{SE}_{7,10}=42$ percent. 
05380990 South Branch O'Neill Creek near Neillsville, Wis.

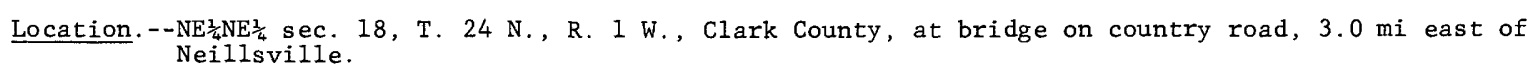

Drainage area. $--22.8 \mathrm{mi}^{2}$.

Tributary to. --O'Neill Creek.

Type of site. --Miscellaneous site.

Discharge measurements.--Oct. $25,1968,2.54 \mathrm{ft}^{3} / \mathrm{s} ;$ Aug. 28, 1969, $0.75 \mathrm{ft}^{3} / \mathrm{s} ;$ Aug. 13, $1970,0.70 \mathrm{ft}^{3} / \mathrm{s}$.

Low-flow frequency. $-\mathrm{Q}_{7,2}=0.41 \mathrm{ft}^{3} / \mathrm{s}, Q_{7,10}=0.10 \mathrm{ft}^{3} / \mathrm{s}$.

Basis of estimate.--Correlated with Black River at Neillsville using 3 discharge measurements.

Accuracy. $--\mathrm{SE}_{7,10}=68$ percent (basin average).

05381000 Black River at Neillsville, Wis.

Location. - - NW $\frac{1}{4} \mathrm{SW}_{\frac{1}{4}} \mathrm{sec}$. 15, T. $24 \mathrm{~N}$., R. 2 W., on right bank at downstream side of bridge on U.S. Highway 10, in Neillsville, 1 mi downstream from 0 'Neill Creek.

Drainage area. $--756 \mathrm{mi}^{2}$.

Tributary to.--Mississippi River.

Type of site.--Gaging station.

Period of record.--April 1905 to March 1909, October 1913 to September 1976. Monthly discharge only for
some periods. Average discharge. --66 years, $580 \mathrm{ft}^{3} / \mathrm{s}$.

Extremes.--Maximum discharge, $48,800 \mathrm{ft}^{3} / \mathrm{s}$ Sept. 10, 1938; minimum discharge, $0.6 \mathrm{ft}^{3} / \mathrm{s} \mathrm{Aug.} 15,1936$.

\begin{tabular}{|l|rrrrrr|}
\hline $\begin{array}{l}\text { Period } \\
\text { of con- } \\
\text { secutive } \\
\text { days }\end{array}$ & \multicolumn{4}{c|}{$\begin{array}{l}\text { Magnitude and frequency of annual low flow } \\
\text { Discharge, in cubic feet per second, for } \\
\text { indicated recurrence interval, in years }\end{array}$} \\
\hline & 2 & 5 & 10 & 20 & 50 & 100 \\
\cline { 2 - 7 } & 26 & 12 & 6.6 & 3.6 & 1.6 & 0.90 \\
7 & 28 & 13 & 7.9 & 4.5 & 2.3 & 1.3 \\
14 & 33 & 17 & 12 & 7.6 & 4.6 & 3.3 \\
30 & 44 & 24 & 17 & 13 & 8.4 & 6.2 \\
60 & 59 & 33 & 25 & 19 & 14 & 11 \\
90 & & & & &
\end{tabular}

\begin{tabular}{|c|c|c|c|c|c|c|c|}
\hline $\begin{array}{l}\text { Discharg } \\
\text { was exce }\end{array}$ & $\begin{array}{l}\text { uration } \\
\text { e, in c } \\
\text { eded fo }\end{array}$ & $\begin{array}{l}\text { table } \\
\text { bic fe } \\
\text { e indic }\end{array}$ & $\begin{array}{l}\text { of dail } \\
\text { et per } \\
\text { ated pe }\end{array}$ & $\begin{array}{l}\text { flc } \\
\text { secor } \\
\text { ecent }\end{array}$ & of $t$ & & \\
\hline Percent & 2 & 5 & 10 & 20 & 30 & 40 & 50 \\
\hline $\mathrm{ft}^{3} / \mathrm{s}$ & 5,200 & 2,720 & 1,400 & 590 & 300 & 182 & 125 \\
\hline Percent & 60 & 70 & 80 & 90 & 95 & 98 & 99.9 \\
\hline $\mathrm{ft}^{3} / \mathrm{s}$ & 90 & 67 & 47 & 33 & 25 & 15 & 2.6 \\
\hline
\end{tabular}

Accuracy. $--\mathrm{SE}_{7,2}=9$ percent, $\mathrm{SE}_{7,10}=23$ percent.

05381010 Cunningham Creek at Lynn, Wis .

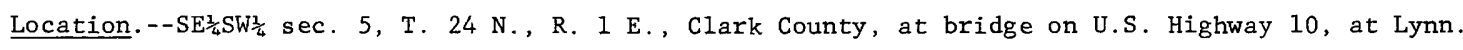

Drainage area. $--2.62 \mathrm{mi}^{2}$.

Tributary to.--Black River.

Type of site.--Miscellaneous site.

Discharge measurements.--Aug. 19, $1976,0.06 \mathrm{ft}^{3} / \mathrm{s} ;$ Aug. $31,1976,0.08 \mathrm{ft}^{3} / \mathrm{s} ;$ Aug. 23, $1977,0.06 \mathrm{ft}^{3} / \mathrm{s}$.

Low-flow frequency. $-Q_{7,2}=0.08 \mathrm{ft}^{3} / \mathrm{s}, Q_{7,10}=0.02 \mathrm{ft}^{3} / \mathrm{s}$.

Basis of estimate.--Correlated with Black River at Neillsville using 3 discharge measurements.

Accuracy. $--\mathrm{SE}_{7,10}=68$ percent (basin average). 
05381040 Cunningham Creek near Neillsville, Wis.

Location. - $-\mathrm{NE} \frac{1}{4} \mathrm{SE} \frac{1}{4} \mathrm{sec} .5$, T. $23 \mathrm{~N} .$, R. $1 \mathrm{~W} .$, Clark County, at country road, 5.7 mi southeast of Neillsville. Drainage area. $--38.9 \mathrm{mi}^{2}$. Tributary to. --Black River.

Type of site.--Miscellaneous site.

Discharge measurements.--Oct. 24, 1968, $3.98 \mathrm{ft}^{3} / \mathrm{s}$; Aug. $28,1969,0.84 \mathrm{ft} / \mathrm{s}$.

Low-flow frequency.--Unable to determine low-flow characteristics, additional discharge measurements are required.

05381055 Cunningham Creek near Neillsville, Wis.

Location.--SE $\frac{1}{4} N E \frac{1}{4}$ sec, 35, T. 24 N., R. 2 W., Clark County, at bridge on country road, 3.1 mi south of
Neillsville.

Drainage area. $--45.2 \mathrm{mi}^{2}$.

Tributary to.--Black River.

Type of site.--Miscellaneous site.

Discharge measurement.--Aug. 13, 1970, $0.44 \mathrm{ft}^{3} / \mathrm{s}$.

Low-flow frequency. $-Q_{7,2}=0.30 \mathrm{ft}^{3} / \mathrm{s}, Q_{7,10}=0.07 \mathrm{ft}^{3} / \mathrm{s}$.

Basis of estimate.--Used regression equations 9 and 10 .

Accuracy. $--\mathrm{SE}_{7,2}=45$ percent, $\mathrm{SE}_{7,10}=76$ percent.

05381060 Cunningham Creek below Jack Creek near Neillsville, Wis.

Location.--SW $\frac{1}{4} \mathrm{NW}_{\frac{1}{4}}$ sec. $26, \mathrm{~T}, 24 \mathrm{~N} ., \mathrm{R} .2 \mathrm{~W}$, , Clark County, at bridge on State Highways 73 and $95,2.0$ mi south of Neillsville.

Drainage area. $--64.2 \mathrm{mi}^{2}$. Tributary to.--Black River.

Type of site.--Miscellaneous site.

Discharge measurements. --Oct. $25,1968,6.29 \mathrm{ft}^{3} / \mathrm{s} ;$ Aug. $28,1969,0.73 \mathrm{ft} / \mathrm{s}$.

Low-flow frequency. $-Q_{7,2}=0.41 \mathrm{ft}^{3} / \mathrm{s}, Q_{7,10}=0.10 \mathrm{ft}^{3} / \mathrm{s}$.

Basis of estimate.--Used regression equations 9 and 10 .

Accuracy. $--\mathrm{SE}_{7,2}=45$ percent, $\mathrm{SE}_{7,10}=76$ percent.

05381080 Wedges Creek near Globe, Wis.

Location.-- - NW $\frac{1}{4} N W \frac{1}{4}$ sec. 26, T. $25 \mathrm{~N} ., \mathrm{R} .3 \mathrm{~W}$., Clark County, at bridge on country road, 3.3 mi southwest of Drainage area. $--40.7 \mathrm{mi}^{2}$. Tributary to.--BIack River.

Type of site.--Miscellaneous site.

Discharge measurements. --0ct. 25, 1968, $7.89 \mathrm{ft}^{3} / \mathrm{s}$; Aug. 28, 1969, $2.43 \mathrm{ft} / \mathrm{s}$.

Low-flow frequency. $--_{7,2}=1.3 \mathrm{ft}^{3} / \mathrm{s}, Q_{7,10}=0.44 \mathrm{ft}^{3} / \mathrm{s}$.

Basis of estimate.--Used regression equations 9 and 10 .

Accuracy. $--\mathrm{SE}_{7,2}=45$ percent, $S E_{7,10}=76$ percent. 
05381090 Wedges Creek near Neillsville, Wis.

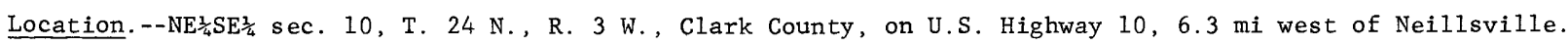
Drainage area. $--60.5 \mathrm{mi}^{2}$. Tributary to.--Black River.

Type of site.--Miscellaneous site.

Discharge measurement.--Aug. 13, 1970, $2.45 \mathrm{ft}^{3} / \mathrm{s}$.

Low-flow frequency. $--_{7,2}=1.6 \mathrm{ft}^{3} / \mathrm{s}, Q_{7,10}=0.54 \mathrm{ft}^{3} / \mathrm{s}$.

Basis of estimate.--Used regression equations 9 and 10 .

Accuracy. $-\mathrm{SE}_{7,2}=45$ percent, $\mathrm{SE}_{7,10}=76$ percent.

05381100 Fivemile Creek near Neillsville, Wis.

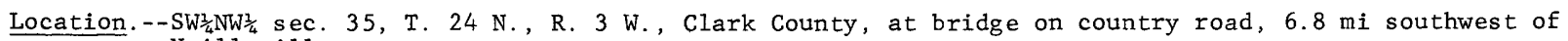
Neillsville.

Drainage area. $--37.1 \mathrm{mi}^{2}$. Tributary to.--Wedges Creek.

Type of site.--Miscellaneous site.

Discharge measurements.--Oct. 25, 1968, $11.0 \mathrm{ft}^{3} / \mathrm{s} ;$ Aug. $28,1969,1.77 \mathrm{ft}^{3} / \mathrm{s}$.

Low-flow frequency. $--_{7,2}=1.6 \mathrm{ft}^{3} / \mathrm{s}, Q_{7,10}=0.59 \mathrm{ft}^{3} / \mathrm{s}$.

Basis of estimate. - Used regression equations 9 and 10.

Accuracy.-- $\mathrm{SE}_{7,2}=45$ percent, $\mathrm{SE}_{7,10}=76$ percent.

05381110 Wedges Creek near Neillsville, Wis.

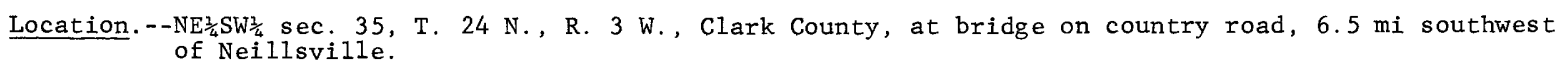

Drainage area. $--114 \mathrm{mi}^{2}$.

Tributary to. --Black River.

Type of site.--Miscellaneous site.

Discharge measurements.--Oct. 25, 1968, 28.8 ft $\mathrm{ft}^{3} / \mathrm{s} ;$ Aug. $28,1969,7.20 \mathrm{ft} / \mathrm{s} ;$ Aug. 13, 1970, $9.98 \mathrm{ft} / \mathrm{s}$. Low-flow frequency. $-Q_{7,2}=6.4 \mathrm{ft}^{3} / \mathrm{s}, Q_{7,10}=1.8 \mathrm{ft}^{3} / \mathrm{s}$.

Basis of estimate. --Correlated with Black River at Neillsville using 3 discharge measurements.

Accuracy. $--\mathrm{SE}_{7,10}=68$ percent (basin average).

05381150 East Fork Black River near Pittsville, Wis.

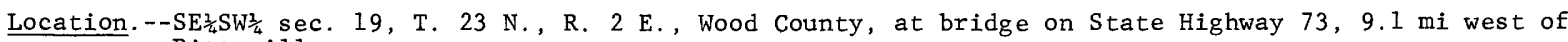
Pittsville.

Drainage area. $--37.2 \mathrm{mi}^{2}$.

Tributary to. --Black River.

Type of site.--Low-flow partial-record station.

Minimum discharge measured. $--0.00 \mathrm{ft}^{3} / \mathrm{s}$, Aug. 22, 1962, Aug. 5, 1964, Aug. 22, 1967, Aug. $11,1970$.

Low-flow frequency. $-Q_{7,2}=0.00 \mathrm{ft}^{3} / \mathrm{s}, Q_{7,10}=0.00 \mathrm{ft}^{3} / \mathrm{s}$. Basis of estimate.-- Correlated with Black River near Neillsville using 12 discharge measurements made during
the period 1962-70.

Accuracy.--Not applicable. 
05381157 Rocky Run near Pittsville, Wis.

Location. - $-\mathrm{NE}^{\frac{1}{4}} \mathrm{NW} \frac{1}{4} \mathrm{sec}$. 11, T. $22 \mathrm{~N} ., \mathrm{R} .2 \mathrm{E}$, Wood County, at bridge on County Trunk V, 5.6 mi southwest Tributary to.--East Fork Black River.

Drainage area. $--40.2 \mathrm{mi}^{2}$.

Type of site.--Miscellaneous site.

Discharge measurements. - - 0ct. 23, 1968, 3.01 ft $\mathrm{ft}^{3} / \mathrm{s}$; Aug. 27, 1969, <0.1 (estimate).

Low-flow frequency.--Unable to determine low-flow characteristics, additional discharge measurements are required.

05381158 East Fork Black River near Pittsville, Wis.

Location.- - NW $\frac{1}{4} N W \frac{1}{4}$ sec. 23, T. 22 N., R. 2 E., Wood County, at bridge on Peterson Road, 6.7 mi southwest of Pittsville.

Drainage area, $--90.1 \mathrm{mi}^{2}$. Tributary to.--Black River.

Type of site.--Miscellaneous site.

Discharge measurement.--Aug. 11, 1970, $0 \mathrm{ft}^{3} / \mathrm{s}$.

Low-flow frequency. $-Q_{7,2}=0 \mathrm{ft}^{3} / \mathrm{s}, Q_{7,10}=0 \mathrm{ft}^{3} / \mathrm{s}$.

Basis of estimate.--Used regression equations 9 and 10 .

Accuracy. --Not applicable.

05381161 Hay Creek near City Point, Wis.

Location.--SW $\frac{3}{4} S W \frac{3}{4}$ sec. 20, T. 22 N., R. 2 E., Wood County, at bridge on country road, 1.7 mi northeast of City Point.

Drainage area. $--30.7 \mathrm{mi}^{2}$. Tributary to.--East Fork Black River.

Type of site.--Miscellaneous site.

Discharge measurements.--0ct. 24, 1968, $4.89 \mathrm{ft}^{3} / \mathrm{s} ;$ Aug. $27,1969,0 \mathrm{ft} / \mathrm{s}$.

Low-flow frequency. $-Q_{7,2}=0 \mathrm{ft}^{3} / \mathrm{s}, Q_{7,10}=0 \mathrm{ft}^{3} / \mathrm{s}$.

Basis of estimate.--Used regression equations 9 and 10 .

Accuracy. - -Not applicable.

05381164 East Fork Black River near City Point, Wis.

Location. - $-\mathrm{SW} \frac{3}{4} \mathrm{SW} \frac{3}{4} \mathrm{sec}, 22, \mathrm{~T} .22 \mathrm{~N} ., \mathrm{R} .1 \mathrm{E}$, Jackson County, at bridge on country road, 2.9 mi northwest of City Point.

Drainage area. $--160 \mathrm{mi}^{2}$. Tributary to.--Black River.

Type of site.--Miscellaneous site.

Discharge measurements.--0ct. $24,1968,40.0 \mathrm{ft}^{3} / \mathrm{s} ;$ Aug. $27,1969,2.57 \mathrm{ft} / \mathrm{s}$.

05381167 East Fork Black River above Rock Creek near City Point, Wis.

Location. - NE$_{\frac{1}{4}} \mathrm{NE}_{\frac{1}{4}} \mathrm{sec} .9, \mathrm{~T} .22 \mathrm{~N} ., \mathrm{R} .1 \mathrm{~W} .$, Jackson County, at bridge on country road, 9.4 mi northwest of City Point.

Drainage area. $--201 \mathrm{mi}^{2}$. Tributary to.--Black River.

Type of site.--Miscellaneous site.

Discharge measurements. -0ct. $24,1968,56.2 \mathrm{ft}^{3} / \mathrm{s} ;$ Aug. $27,1969,4.61 \mathrm{ft} / \mathrm{s} ; \mathrm{Aug} .11,1970,4.10 \mathrm{ft} / \mathrm{s}$. Low-flow frequency. $-\mathrm{Q}_{7,2}=3.2 \mathrm{ft}^{3} / \mathrm{s}, \mathrm{Q}_{7,10}=0.98 \mathrm{ft}^{3} / \mathrm{s}$.

Basis of estimate.--Correlated with Yellow River at Babcock using 3 discharge measurements.

Accuracy. $--\mathrm{SE}_{7,10}=68$ percent (basin average). 
05381170 Rock Creek near Nei11svi11e, Wis.

Location.--SW $\frac{1}{4}$ sec. 26, T. 23 N., R. 2 W., Clark County, at bridge on country road, 8.4 mi south of
Neillsville.

Drainage area. $--27.8 \mathrm{mi}^{2}$.

Tributary to.--East Fork Black River.

Type of site.--Low-flow partial-record station.

Minimum discharge measured.--0.00 ft $\mathrm{f}^{3} / \mathrm{s}$, ponded with no observable velocities, Aug. 23, 1967, Aug. 18, 1969, Aug. 11, 1970, Aug. 19, 1975 .

Low-flow frequency. $-Q_{7,2}=0 \mathrm{ft}^{3} / \mathrm{s}, Q_{7,10}=0 \mathrm{ft}^{3} / \mathrm{s}$.

Basis of estimate.--Correlated with Yellow River at Babcock based on 16 discharge measurements made during the period 1962-76.

Accuracy. - Not applicable.

05381173 East Fork Black River near Hatfield, Wis.

Location. - -
Hatfield.

Drainage area. $--252 \mathrm{mi}^{2}$.

Tributary to. --Black River.

Type of site.--Miscellaneous site.

Discharge measurement. --Aug. $11,1970,3.97 \mathrm{ft}^{3} / \mathrm{s}$.

05381240 Morrison Creek near Hatfield, Wis.

Location. - $-\mathrm{NE} \frac{1}{4} \mathrm{NE} \frac{1}{4} \mathrm{sec} .22$, T. $22 \mathrm{~N} .$, R. 3 W., Jackson County, at bridge on County Trunk K, 2.6 mi south of Hatfield.

Drainage area. $--102 \mathrm{mi}^{2}$. Tributary to.--Black River.

Type of site.--Miscellaneous site.

Discharge measurement.--Aug. $11,1970,8.75 \mathrm{ft}^{3} / \mathrm{s}$.

Low-flow frequency.--Unable to determine low-flow characteristics by the equations. The area for this station includes glaciated area and driftless area.

05381250 Hay Creek near Hatfield, Wis.

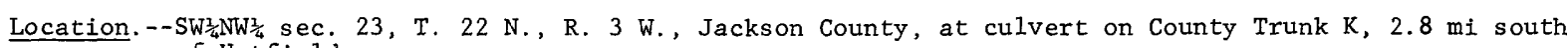
of Hatfield.

Drainage area. $--7.04 \mathrm{mi}^{2}$. Tributary to. - Morrison Creek

Type of site.--Miscellaneous site.

Discharge measurement.--Aug. $11,1970,1.16 \mathrm{ft}^{3} / \mathrm{s}$.

Low-flow frequency.--Unable to determine low-flow characteristics by the equations. The area for this station includes glaciated area and driftless area.

05381260 Dickey Creek near Hatfield, Wis.

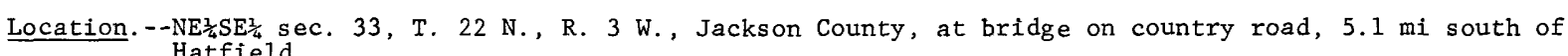
Hatfield.

Drainage area. $--10.6 \mathrm{mi}^{2}$.

Tributary to.--Morrison Creek.

Type of site.--Miscellaneous site.

Discharge measurement.--Aug. 11, 1970, $1.81 \mathrm{ft}^{3} / \mathrm{s}$.

Low-flow frequency.--Unable to determine low-flow characteristics by the equations. The area for this station includes glaciated area and driftless area. 
Table 1.--Low-flow characteristics for sites in the Trempealeau-Black River basin--Continued

05381283 South Fork Halls Creek at Alma Center, Wis.

Location.-- $\mathrm{SE}_{\frac{1}{4}}^{\frac{1}{4} \mathrm{SW}_{\frac{1}{4}}}$ sec. 30, T. $22 \mathrm{~N}$, , R. 4 W., Jackson County, at bridge on County Trunk F, $0.1 \mathrm{mi}$ above sewage-treatment plant, at Alma Center.

Drainage area. $--6.16 \mathrm{mi}^{2}$. Tributary to -- Halls Creek.

Type of site.--Miscellaneous site.

Minimum discharge measured.--1 $18 \mathrm{ft}^{3} / \mathrm{s}$, Sept. 1, 1976.

Low-flow frequency. $-Q_{7,2}=1.3 \mathrm{ft}^{3} / \mathrm{s}, Q_{7,10}=0.80 \mathrm{ft}^{3} / \mathrm{s}$

Basis of estimate.--Correlated with Trempealeau River at Dodge using 8 discharge measurements made during the period 1972-76.

Accuracy.-- $\mathrm{SE}_{7,2}=22$ percent, $\mathrm{SE}_{7,10}=31$ percent.

05381285 Halls Creek at Merrillan, Wis.

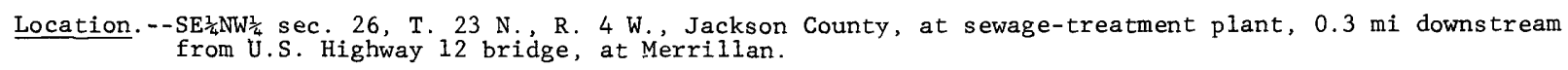

Drainage area. $--46.3 \mathrm{mi}^{2}$. Tributary to. --Black River.

Type of site.--Miscellaneous site.

Minimum discharge measured. $--16.7 \mathrm{ft}^{3} / \mathrm{s}$, July $31,1974$.

Low-flow frequency. $-Q_{7,2}=12 \mathrm{ft}^{3} / \mathrm{s}, Q_{7,10}=8.4 \mathrm{ft}^{3} / \mathrm{s}$. Basis of estimate.-- Correlated with Trempealeau River at Dodge using 8 discharge measurements made during

Accuracy. $--\mathrm{SE}_{7,2}=14$ percent, $\mathrm{SE}_{7,10}=18$ percent.

05381290 Halls Creek near Black River Falls, Wis. Location. - - $-\mathrm{SW}_{\frac{2}{4}} \mathrm{SE} \frac{3}{4}$ sec. 19, T. 22 N., R. 3 W., Jackson County, at bridge on County Trunk E, 5.7 mi northeast
of Black River Falis.

Drainage area. $--90.9 \mathrm{mi}^{2}$. Tributary to. --Black River.

Type of site.--Miscellaneous site.

Discharge measurement.--Aug. 10, 1970, $20.4 \mathrm{ft}^{3} / \mathrm{s}$.

Low-flow frequency. $-Q_{7,2}=19 \mathrm{ft}^{3} / \mathrm{s}, Q_{7,10}=14 \mathrm{ft}^{3} / \mathrm{s}$.

Basis of estimate. --Used regression equations 6 and 8 .

Accuracy. $--\mathrm{SE}_{7,2}=16$ percent, $\mathrm{SE}_{7,10}=22$ percent.

05381350 Levis Creek near Black River Falls, Wis.

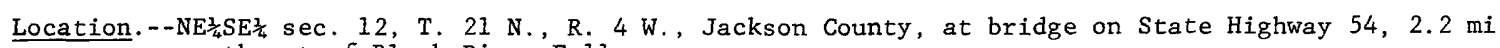
northeast of Black River Falls.

Drainage area. $--39.7 \mathrm{mi}^{2}$. Tributary to. --Black River.

Type of site.--Low-flow partial-record station.

Minimum discharge measured. $--5.03 \mathrm{ft}^{3} / \mathrm{s}$, Aug. 17, 1964.

Low-flow frequency. $-Q_{7,2}=7.0 \mathrm{ft}^{3} / \mathrm{s}, Q_{7,10}=4.4 \mathrm{ft}^{3} / \mathrm{s}$.

Basis of estimate.--Correlated with Trempealeau River at Dodge using 15 discharge measurements made during the period 1964-76.

Accuracy. $--\mathrm{SE}_{7,2}=9$ percent, $\mathrm{SE}_{7,10}=15$ percent. 
Table 1.--Low-flow characteristics for sites in the Trempealeau-Black River basin--Continued

05381400 Robinson Creek near Black River Falls, Wis.

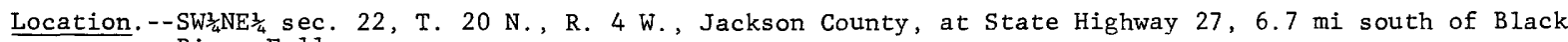
River Falls.

Drainage area. $--108 \mathrm{mi}^{2}$.

Tributary to. --Black River.

Type of site.--Miscellaneous site.

Discharge measurement.--Aug. 12, $1970,45.5 \mathrm{ft}^{3} / \mathrm{s}$.

Low-flow frequency. $--_{7,2}=35 \mathrm{ft}^{3} / \mathrm{s}, Q_{7,10}=27 \mathrm{ft}^{3} / \mathrm{s}$.

Basis of estimate.--Used regression equations 6 and 8 .

Accuracy.-- $-\mathrm{SE}_{7,2}=16$ percent, $\mathrm{SE}_{7,10}=22$ percent.

05381420 Trout Run near Melrose, Wis.

Location. --SW $\frac{1}{4} \mathrm{SW}_{\frac{1}{4}} \mathrm{sec} .13$, T. $20 \mathrm{~N}$., R. 5 W., Jackson County, at bridge on country road, 6.0 mi northeast of Melrose.

Drainage area. $--23.7 \mathrm{mi}^{2}$. Tributary to. --Black River.

Type of site.--Miscellaneous site.

Discharge measurement.--Aug. $12,1970,8.88 \mathrm{ft}^{3} / \mathrm{s}$.

Low-flow frequency. $-Q_{7,2}=6.8 \mathrm{ft}^{3} / \mathrm{s}, Q_{7,10}=4.8 \mathrm{ft}^{3} / \mathrm{s}$.

Basis of estimate.--Used regression equations 6 and 8 .

Accuracy. $--\mathrm{SE}_{7,2}=16$ percent, $\mathrm{SE}_{7,10}=22$ percent.

05381450 Big Creek near Cataract, Wis.

Location. - -NE $\frac{1}{4} \mathrm{SW}_{\frac{1}{4}} \mathrm{sec} .7$, T. $19 \mathrm{~N} .$, R. 4 W., Monroe County, at country road, 4.6 mi northwest of Cataract. Drainage area. $--64.0 \mathrm{mi}^{2}$. Tributary to. --Black River.

Type of site.--Low-flow partial-record station.

Minimum discharge measured. $--32.5 \mathrm{ft}^{3} / \mathrm{s}$, Aug. 17, 1964.

Low-flow frequency. $-Q_{7,2}=33 \mathrm{ft}^{3} / \mathrm{s}, Q_{7,10}=24 \mathrm{ft}^{3} / \mathrm{s}$.

Basis of estimate.--Correlated with LaCrosse River near West Salem using 10 discharge measurements made during the period 1964-76.

Accuracy. $--\mathrm{SE}_{7,2}=5$ percent, $\mathrm{SE}_{7,10}=10$ percent.

\section{Douglas Creek at Melrose, Wis.}

Location.--SW $\frac{1}{4} \mathrm{SW}_{\frac{1}{4}} \mathrm{sec} .9$, T. $19 \mathrm{~N} .$, R. 5 W. , Jackson County, at bridge on County Trunk E, just upstream from sewage-treatment plant, at Melrose.

Drainage area. $--22.9 \mathrm{mi}^{2}$. Tributary to. --Black River.

Type of site.--Miscellaneous site.

Minimum discharge measured. $--9.01 \mathrm{ft}^{3} / \mathrm{s}$, Aug. 12, 1970.

Low-flow frequency. $-Q_{7,2}=7.8 \mathrm{ft}^{3} / \mathrm{s}, Q_{7,10}=5.6 \mathrm{ft}^{3} / \mathrm{s}$.

Basis of estimate. --Correlated with Trempealeau River at Dodge using 8 discharge measurements made during the period 1970-76.

Accuracy.- $-\mathrm{SE}_{7,2}=11$ percent, $\mathrm{SE}_{7,10}=17$ percent. 
05381500 Black River at Melrose, Wis.

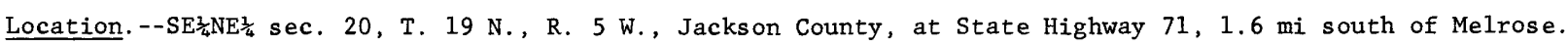

Drainage area. --

Tributary to. --Mississippi River.

Type of site.--Miscellaneous site.

Discharge measurements.--Jan. 15, 1903, $598 \mathrm{ft}^{3} / \mathrm{s} ; \mathrm{Feb} .7,1903,508 \mathrm{ft}^{3} / \mathrm{s}$; June 13, 1903, $842 \mathrm{ft}^{3} / \mathrm{s}$.

Low-flow frequency.--Unable to define relationship, additional discharge measurements are required.

\section{Fleming Creek at Stevenstown, Wis.}

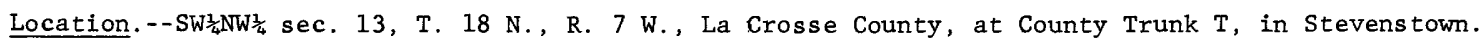

Drainage area. $--28.5 \mathrm{mi}^{2}$. Tributary to.--Black River.

Type of site.--Low-flow partial-record station.

Minimum discharge measured. $--8.13 \mathrm{ft}^{3} / \mathrm{s}$, July 12, 1967.

Low-flow frequency. $-Q_{7,2}=7.3 \mathrm{ft}^{3} / \mathrm{s}, Q_{7,10}=5.1 \mathrm{ft}^{3} / \mathrm{s}$.

Basis of estimate.--Correlated with Trempealeau River at Dodge using 9 discharge measurements made during the period 1967-76.

Accuracy. $--\mathrm{SE}_{7,2}=16$ percent, $\mathrm{SE}_{7,10}=31$ percent.

05381810 Sour Creek at Stevenstown, Wis.

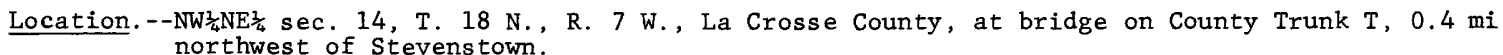

Drainage area. $--5.76 \mathrm{mi}^{2}$.

Tributary to.--Fleming Creek.

Type of site.--Miscellaneous site.

Discharge measurement.--Sept. 8, 1966, $1.01 \mathrm{ft}^{3} / \mathrm{s}$.

Low-flow frequency. $-Q_{7,2}=1.0 \mathrm{ft}^{3} / \mathrm{s}, Q_{7,10}=0.62 \mathrm{ft}^{3} / \mathrm{s}$.

Basis of estimate.--Used regression equations 6 and 8 .

Accuracy. $--\mathrm{SE}_{7,2}=16$ percent, $\mathrm{SE}_{7,10}=22$ percent. 
05382000 Black River near Galesville, Wis.

Location. - $-\mathrm{NE} \frac{1}{4} \mathrm{SE} \frac{1}{4} \mathrm{sec} .2$, T. $18 \mathrm{~N} .$, R. $8 \mathrm{~W}$. , La Crosse County, at U.S. Highway 53 , 3.2 mi southeast of Galesville.

Drainage area. $--2,120 \mathrm{mi}^{2}$. Tributary to.--Mississippi River.

Type of site.--Gaging station.

Period of record.--December 1931 to September 1976.

Average discharge. -44 years, 1,683 $\mathrm{ft}^{3} / \mathrm{s}$.

Extremes.--Maximum discharge, 65,500 $\mathrm{ft}^{3} / \mathrm{s}$ Apr. 1, 1967; minimum discharge, $180 \mathrm{ft} / \mathrm{s}$ Dec. $20,1932$.

\begin{tabular}{|c|c|c|c|c|c|c|}
\hline \multirow[t]{2}{*}{$\begin{array}{l}\text { Period } \\
\text { of con- } \\
\text { secutive } \\
\text { days }\end{array}$} & \multicolumn{6}{|c|}{$\begin{array}{l}\text { Magnitude and frequency of annual low flow } \\
\text { Discharge, in cubic feet per second, for } \\
\text { indicated recurrence interval, in years }\end{array}$} \\
\hline & 2 & 5 & 10 & 20 & 50 & 100 \\
\hline $\begin{array}{r}7 \\
14 \\
30 \\
60 \\
90\end{array}$ & $\begin{array}{l}344 \\
355 \\
380 \\
433 \\
496\end{array}$ & $\begin{array}{l}284 \\
293 \\
313 \\
340 \\
372\end{array}$ & $\begin{array}{l}259 \\
268 \\
287 \\
305 \\
325\end{array}$ & $\begin{array}{l}241 \\
251 \\
270 \\
281 \\
293\end{array}$ & $\begin{array}{l}223 \\
234 \\
253 \\
258 \\
262\end{array}$ & $\begin{array}{l}213 \\
224 \\
244 \\
246 \\
246\end{array}$ \\
\hline
\end{tabular}

\begin{tabular}{|l|rrrrrr|}
\hline \multicolumn{7}{|c|}{ Duration table of daily flow } \\
Discharge, in cubic feet per second, which \\
was exceeded for indicated percent of time \\
\hline $\begin{array}{l}\text { Percent } \\
\mathrm{ft}^{3} / \mathrm{s}\end{array}$ & 10,000 & 5,950 & 3,650 & 2,080 & 1,400 & 1,000 \\
\hline Percent & 50 & 60 & 70 & 80 & 90 & 95 \\
$\mathrm{ft}^{3} / \mathrm{s}$ & 770 & 625 & 520 & 430 & 365 & 326 \\
\hline Percent & 98 & 99.9 & & & & \\
$\mathrm{ft}^{3} / \mathrm{s}$ & 290 & 225 & & & & \\
\hline
\end{tabular}

Accuracy. $-\mathrm{SE}_{7,2}=4$ percent, $\mathrm{SE}_{7,10}=5$ percent.

Remarks.--Flow partially regulated by Hatfield dam powerplant. Water is diverted periodically from basin into Lemonweir River basin for cranberry culture.

05382010 Beaver Creek near Taylor, Wis.

Location.--NW $\frac{1}{4} S W \frac{1}{4}$ sec. 10, T. 20 N., R. 6 W., Jackson County, at culvert on County Trunk C, 7.1 mi south of Taylor.

Drainage area.--

Tributary to. --Black River.

Type of site.--Miscellaneous site.

Discharge measurements.--Aug. 18, 1970, $1.22 \mathrm{ft}^{3} / \mathrm{s} ;$ Aug. 19, 1975, $1.56 \mathrm{ft} / \mathrm{s}$.

05382015 Beaver Creek near Taylor, Wis.

Location.- - NW $\frac{1}{4} \mathrm{NE} \frac{1}{4} \mathrm{sec} .17, \mathrm{~T} .20 \mathrm{~N} .$, R. $6 \mathrm{~W}$, Jackson County, at bridge on country road, 7.4 mi south of Taylor.

Drainage area.--

Tributary to. --Black River.

Type of site.--Miscellaneous site.

Discharge measurements.--Aug. 18, 1970, 3.30 ft $\mathrm{f}^{3} / \mathrm{s} ;$ Aug. 19, 1975, 4.14 $\mathrm{ft} / \mathrm{s}$.

05382018 Beaver Creek tributary near Ettrick, Wis.

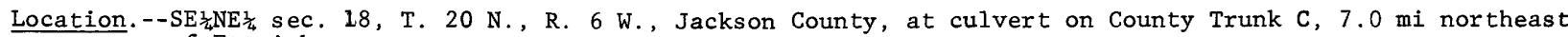
of Ettrick.

Drainage area.--

Tributary to.--Beaver Creek.

Type of site.--Miscellaneous site.

Discharge measurements.--Aug. 19, 1970, $0.39 \mathrm{ft}^{3} / \mathrm{s} ;$ Aug. 19, 1975, $0.67 \mathrm{ft} / \mathrm{s}$. 


\section{Beaver Creek near Ettrick, Wis.}

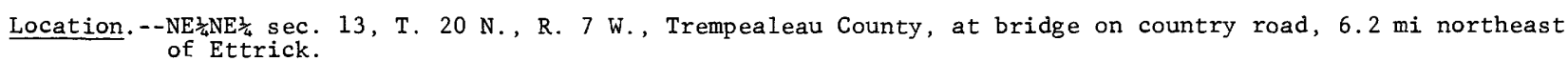

Drainage area.-Tributary to. --Black River.

Type of site.--Miscellaneous site.

Discharge measurements.--Aug. 20, 1970, 4.43 ft $\mathrm{ft}^{3} / \mathrm{s}$; Aug. 19, 1975, $7.37 \mathrm{ft}^{3} / \mathrm{s}$. 05382025 Beaver Creek tributary near Ettrick, Wis.

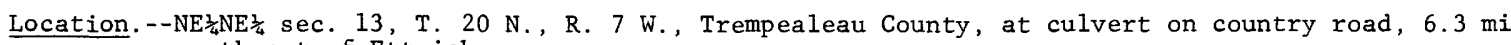
northeast of Ettrick.

Drainage area.-Tributary to.--Beaver Creek.

Type of site.--Miscellaneous site.

Discharge measurements.--Aug. 20, 1970, $0.48 \mathrm{ft}^{3} / \mathrm{s} ;$ Aug. 19, 1975, $0.86 \mathrm{ft}^{3} / \mathrm{s}$.

05382027 Beaver Creek near Ettrick, Wis. Location.-- $\begin{gathered}\text { SE } \frac{1}{4} N E \frac{1}{4} \mathrm{sec} .14, \mathrm{~T} .20 \mathrm{~N} ., \mathrm{R} .7 \mathrm{~W} ., \text { Trempealeau County, at bridge on country road, } 5.3 \text { mi } \\ \text { northeast of Ettrick. }\end{gathered}$

Drainage area.--

Tributary to. --Black River.

Type of site.--Miscellaneous site.

Discharge measurements.--Aug. 20, 1970, $5.61 \mathrm{ft}^{3} / \mathrm{s}$; Aug. 19, 1975, $7.81 \mathrm{ft} / \mathrm{s}$.

05382032 Washington Coulee near Ettrick, Wis.

Location. --SW $\frac{1}{4} \mathrm{NE} \frac{1}{4} \mathrm{sec} .14, \mathrm{~T}, 20 \mathrm{~N} .$, R. $7 \mathrm{~W}$, Trempealeau County, at bridge on County Trunk C, 5.2 mi northeast of Ettrick.

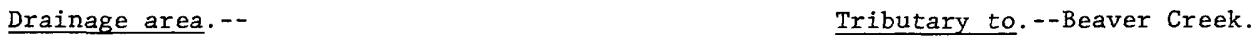

Type of site.--Miscellaneous site.

Discharge measurements.--Aug. 20, 1970, $0.92 \mathrm{ft}^{3} / \mathrm{s}$; Aug. 19, 1975, 1.50 $\mathrm{ft}^{3} / \mathrm{s}$.

05382037 Beaver Creek near Ettrick, Wis. Location. - $-\mathrm{NW} \frac{1}{4} \mathrm{NW} \frac{1}{4} \mathrm{sec} .15, \mathrm{~T}, 20 \mathrm{~N} ., \mathrm{R} .7 \mathrm{~W} .$, Trempealeau County, at bridge on country road, 4.0 mi
northeast of Ettrick.

Drainage area.--

Tributary to.--Black River.

Type of site.--Miscellaneous site.

Discharge measurements.--Aug. 20,1970, $9.16 \mathrm{ft}^{3} / \mathrm{s}$; Aug. 19,1975, 13.6 ft $\mathrm{ft}^{3}$.

05382040 Beaver Creek near Ettrick, Wis.

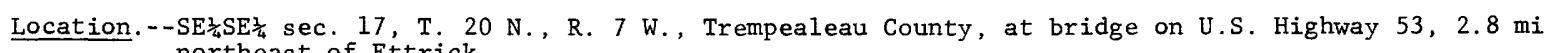
northeast of Ettrick.

Drainage area.--

Tributary to.--Black River.

Type of site.--Miscellaneous site.

Discharge measurements.--Aug. 20,1970,10.1 ft $\mathrm{ft}^{3} / \mathrm{s}$; Aug. 19, 1975, $15.0 \mathrm{ft} / \mathrm{s}$. 
05382044 Bear Creek near Ettrick, Wis.

Location. - - $-\mathrm{SW}_{\frac{1}{4}} \mathrm{NE}^{\frac{1}{4}} \mathrm{sec} .8$, T. $20 \mathrm{~N} .$, R. $7 \mathrm{~W}$., Trempealeau County, at bridge on country road, $4.0 \mathrm{mi}$ north of Ettrick.

Drainage area.--

Tributary to.--Beaver Creek.

Type of site.--Miscellaneous site.

Discharge measurements.--Aug. 20, 1970, $1.06 \mathrm{ft}^{3} / \mathrm{s} ;$ Aug. 19, 1975, $1.80 \mathrm{ft}^{3} / \mathrm{s}$.

05382048 Bear Creek tributary near Ettrick, Wis.

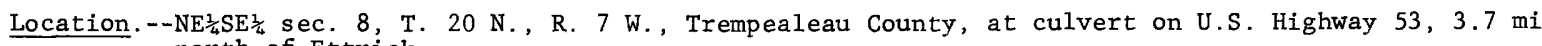
north of Ettrick.

Drainage area.--

Tributary to. --Bear Creek.

Type of site.--Miscellaneous site.

Discharge measurements.--Aug. $20,1970,0.52 \mathrm{ft}^{3} / \mathrm{s} ;$ Aug. $19,1975,1.18 \mathrm{ft}^{3} / \mathrm{s}$.

05382051 Bear Creek near Ettrick, Wis.

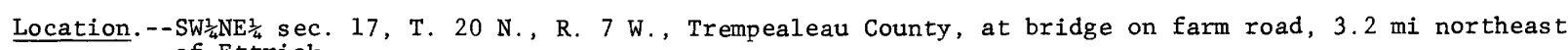
of Ettrick.

Drainage area.--

Tributary to.--Beaver Creek.

Type of site.--Miscellaneous site.

Discharge measurements.--Aug. $20,1970,2.18 \mathrm{ft}^{3} / \mathrm{s}$; Aug. 19, 1975, $3.78 \mathrm{ft}^{3} / \mathrm{s}$.

05382060 Beaver Creek at Ettrick, Wis.

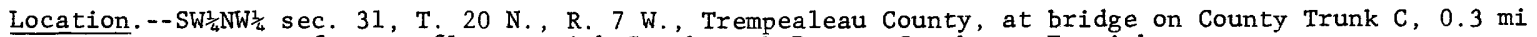
upstream from confluence with South Fork Beaver Creek, at Ettrick.

Drainage area. $--51.0 \mathrm{mi}^{2}$.

Tributary to.--Black River.

Type of site.--Miscellaneous site.

Minimum discharge measured. $--17.4 \mathrm{ft}^{3} / \mathrm{s}$, Aug. 10,1974 .

Low-flow frequency. $-Q_{7,2}=14 \mathrm{ft}^{3} / \mathrm{s}, Q_{7,10}=9.2 \mathrm{ft}^{3} / \mathrm{s}$.

Basis of estimate.--Correlated with Trempealeau River at Dodge using 8 discharge measurements made during the period 1970-76.

Accuracy. $--\mathrm{SE}_{7,2}=9$ percent, $\mathrm{SE}_{7,10}=10$ percent.

05382065 South Fork Beaver Creek tributary near North Bend, Wis.

Location. - - SW $\frac{1}{4} \mathrm{SW}_{\frac{1}{4}} \mathrm{sec} .4$, T. $19 \mathrm{~N}$, , R. $6 \mathrm{~W}$., Jackson County, at bridge on country road, $3.8 \mathrm{mi}$ north of North Bend.

Drainage area.--

Tributary to. --South Fork Beaver Creek.

Type of site.--Miscellaneous site.

Discharge measurements.--Aug. $18,1970,0.1 \mathrm{ft}^{3} / \mathrm{s} ;$ Aug. $18,1975,0.06 \mathrm{ft}^{3} / \mathrm{s}$. 
05382067 South Fork Beaver Creek near North Bend, Wis.

Location. - - SE $\frac{1}{4} \mathrm{SW} \frac{1}{4} \mathrm{sec} .5, \mathrm{~T} .19 \mathrm{~N}$, R. $6 \mathrm{~W}$. , Jackson County, at bridge on country road, 3.7 mi north of North Bend.

Drainage area. - -

Tributary to.--Beaver Creek.

Type of site.--Miscellaneous site.

Discharge measurement.--Aug. 18, 1970, $0.00 \mathrm{ft}^{3} / \mathrm{s}$.

Low-flow frequency. $-Q_{7,2}=0 \mathrm{ft}^{3} / \mathrm{s}, Q_{7,10}=0 \mathrm{ft}^{3} / \mathrm{s}$.

Basis of estimate.--Used regression equations 6 and 8 .

Accuracy. --Not applicable.

05382071 German Coulee near North Bend, Wis.

Location.--SW $\frac{1}{4} \mathrm{NE} \frac{1}{4} \mathrm{sec} .32$, T. $20 \mathrm{~N}$., R. $6 \mathrm{~W}$, Jackson County, at bridge on country road, 5.1 mi north of

Drainage area.--

Tributary to.--South Fork Beaver Creek.

Type of site.--Miscellaneous site.

Discharge measurements.--Aug. 18, 1970, $0.30 \mathrm{ft}^{3} / \mathrm{s} ;$ Aug. 18, 1975, $0.49 \mathrm{ft} / \mathrm{s}$.

05382072 German Coulee near North Bend, Wis.

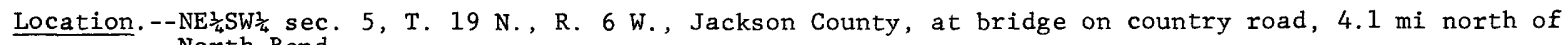
North Bend.

Drainage area.--

Tributary to.--South Fork Beaver Creek.

Type of site.--Miscellaneous site.

Discharge measurement.--Aug. 18, 1970, $0.00 \mathrm{ft}^{3} / \mathrm{s}$.

Low-flow frequency. $-Q_{7,2}=0 \mathrm{ft}^{3} / \mathrm{s}, Q_{7,10}=0 \mathrm{ft}^{3} / \mathrm{s}$.

Basis of estimate.--Used regression equations 6 and 8 .

Accuracy. --Not applicable.

05382076 South Fork Beaver Creek near North Bend, Wis.

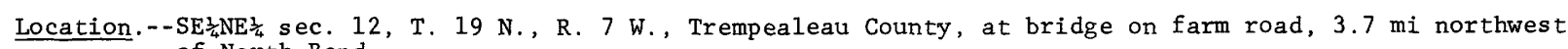
of North Bend.

Drainage area. - -

Tributary to. --Beaver Creek.

Type of site.--Miscellaneous site.

Discharge measurements.--Aug. 18, 1970, $1.50 \mathrm{ft}^{3} / \mathrm{s}$; Aug. 18, 1975, $2.13 \mathrm{ft}^{3} / \mathrm{s}$.

05382080 South Fork Beaver Creek near North Bend, Wis.

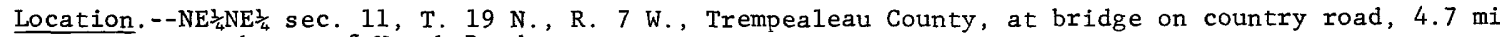
northwest of North Bend.

Drainage area. --

Tributary to.--Beaver Creek.

Type of site.--Miscellaneous site.

Discharge measurements.--Aug. 17, 1970, $1.71 \mathrm{ft}^{3} / \mathrm{s}$; Aug. 18, 1975, 2.55 $\mathrm{ft}^{3} / \mathrm{s}$. 
05382087 Salzwedel Coulee near Ettrick, Wis.

Location. $--\mathrm{SW}_{4} \mathrm{NW} / \frac{1}{4} \mathrm{sec}$.
Ettrick. Drainage area.-Tributary to. --South Fork Beaver Creek.

Type of site.--Miscellaneous site.

Discharge measurements.--Aug. $17,1970,1.30 \mathrm{ft}^{3} / \mathrm{s} ;$ Aug. $18,1975,1.38 \mathrm{ft}^{3} / \mathrm{s}$.

05382089 South Fork Beaver Creek tributary near Ettrick, Wis.

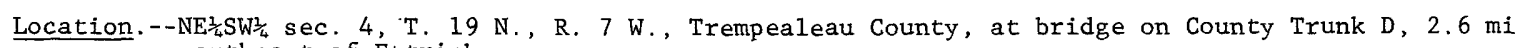
southeast of Ettrick.

Drainage area.-Tributary to.--South Fork Beaver Creek.

Type of site.--Miscellaneous site.

Discharge measurement. --Aug. 18, 1975, $0.006 \mathrm{ft}^{3} / \mathrm{s}$.

05382093 South Fork Beaver Creek near Ettrick, Wis.

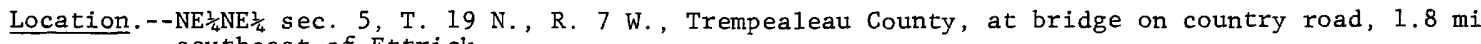
southeast of Ettrick.

Drainage area.-Tributary to.--Beaver Creek.

Type of site.--Miscellaneous site.

Discharge measurements.--Aug. 18, 1970, $5.24 \mathrm{ft}^{3} / \mathrm{s} ;$ Aug. 18, 1975, $6.46 \mathrm{ft}^{3} / \mathrm{s}$.

05382098 Stensven Coulee near Ettrick, Wis.

Location.-- $-\mathrm{SE}_{\frac{1}{4}} \mathrm{SE}_{\frac{1}{4}} \mathrm{sec} .31, \mathrm{~T} .20 \mathrm{~N} ., \mathrm{R} .7 \mathrm{~W}$., Trempealeau County, at bridge on County Trunk D, $1.0 \mathrm{mi}$ southeast of Ettrick.

Drainage area.--

Tributary to. --South Fork Beaver Creek.

Type of site.--Miscellaneous site.

Discharge measurement.--Aug. $18,1975,0.18 \mathrm{ft}^{3} / \mathrm{s}$.

05382100 South Fork Beaver Creek at Ettrick, Wis.

Location.--SE $\frac{1}{4} \mathrm{NW}_{\frac{1}{4}} \mathrm{sec} .31$, T. $20 \mathrm{~N}$., R. $7 \mathrm{~W}$., Trempealeau County, at bridge on County Trunk D, $0.3 \mathrm{mi}$ upstream from Beaver Creek, $0.2 \mathrm{mi}$ south of Ettrick.

Drainage area. $--33.1 \mathrm{mi}^{2}$.

Tributary to.--Beaver Creek.

Type of site.--Low-flow partial-record station.

Minimum discharge measured.--4.22 ft $\mathrm{ft}^{3} / \mathrm{s}$, Aug. 19, 1964.

Low-flow frequency. $--Q_{7,2}=6.1 \mathrm{ft}^{3} / \mathrm{s}, Q_{7,10}=4.4 \mathrm{ft}^{3} / \mathrm{s}$.

Basis of estimate.--Correlated with Trempealeau River at Dodge using 11 discharge measurements made during the period 1964-70.

Accuracy. $--\mathrm{SE}_{7,2}=6$ percent, $\mathrm{SE}_{7,10}=11$ percent. 
Table 1.--Low-flow characteristics for sites in the Trempealeau-Black River basin--Continued

05382120 Beaver Creek near Ettrick, Wis.

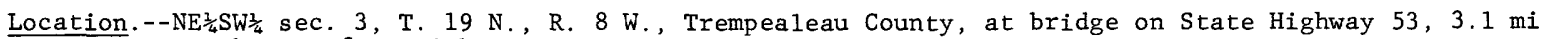
southwest of Ettrick.

Drainage area. $--98.5 \mathrm{mi}^{2}$. Tributary to. - -Black River.

Type of site.--Miscellaneous site.

Discharge measurements.--Aug. 20, 1970, $26.6 \mathrm{ft}^{3} / \mathrm{s} ;$ Aug. 19, 1975, $41.4 \mathrm{ft}^{3} / \mathrm{s}$.

Low-flow frequency. $-Q_{7,2}=28 \mathrm{ft}^{3} / \mathrm{s}, Q_{7,10}=21 \mathrm{ft}^{3} / \mathrm{s}$.

Basis of estimate.--Used regression equations 6 and 8 .

Accuracy. $--\mathrm{SE}_{7,2}=22$ percent, $\mathrm{SE}_{7,10}=16$ percent.

05382130 French Creek near Ettrick, Wis.

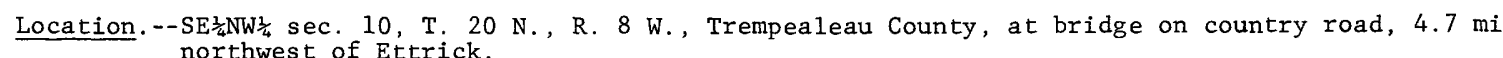

Drainage area. $--2.04 \mathrm{mi}^{2}$.

Tributary to.--Beaver Creek.

Type of site.--Miscellaneous site.

Discharge measurement.--Aug. 20, 1970,0.92 $\mathrm{ft}^{3} / \mathrm{s}$.

Low-flow frequency. $-\mathrm{Q}_{7,2}=0.67 \mathrm{ft}^{3} / \mathrm{s}, \mathrm{Q}_{7,10}=0.42 \mathrm{ft}^{3} / \mathrm{s}$.

Basis of estimate.--Used regression equations 6 and 8 .

Accuracy. $--\mathrm{SE}_{7,2}=16$ percent, $\mathrm{SE}_{7,10}=22$ percent.

05382150 French Creek near Ettrick, Wis.

Location. - - $\mathrm{SE}_{\frac{1}{4}} \mathrm{NE}_{\frac{1}{4}} \mathrm{sec} .15$, T. $20 \mathrm{~N}$., R. 8 W., Trempealeau County, $3.6 \mathrm{mi}$ northwest of Ettrick.

Drainage area. $--7.54 \mathrm{mi}^{2}$.

Tributary to. --Beaver Creek.

Type of site.--Miscellaneous site.

Discharge measurement. --Aug. 20, 1970, $2.72 \mathrm{ft}^{3} / \mathrm{s}$.

Low-flow frequency. $-Q_{7,2}=2.2 \mathrm{ft}^{3} / \mathrm{s}, Q_{7,10}=1.4 \mathrm{ft}^{3} / \mathrm{s}$.

Basis of estimate.--Used regression equations 6 and 8 .

Accuracy. $--\mathrm{SE}_{7,2}=16$ percent, $\mathrm{SE}_{7,10}=22$ percent.

05382160 French Creek tributary near Ettrick, Wis. Location. $--\mathrm{SE}_{\frac{1}{4}} \mathrm{NE} \frac{3}{4} \mathrm{sec} .15, \mathrm{~T} .20 \mathrm{~N} ., \mathrm{R} .8 \mathrm{~W}$. , Trempealeau County, at culverts on County Trunks D and T,
$\quad 3.6 \mathrm{mi}$ northwest of Ettrick.

Drainage area. $--1.82 \mathrm{mi}^{2}$. Tributary to -- French Creek.

Type of site.--Miscellaneous site.

Discharge measurement.--Aug. $20,1970,0.49 \mathrm{ft}^{3} / \mathrm{s}$.

Low-flow frequency. $-Q_{7,2}=0.41 \mathrm{ft}^{3} / \mathrm{s}, Q_{7,10}=0.25 \mathrm{ft}^{3} / \mathrm{s}$.

Basis of estimate.--Used regression equations 6 and 8 .

Accuracy.--SE $7,2=16$ percent, $\mathrm{SE}_{7,10}=22$ percent. 
05382180 French Creek tributary near Ettrick, Wis.

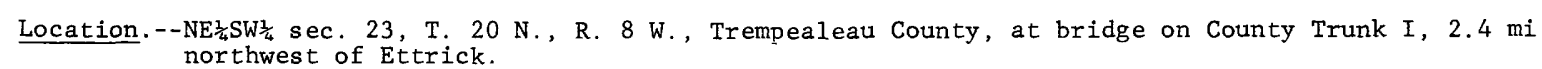
Drainage area. $--2.22 \mathrm{mi}^{2}$. Tributary to. --French Creek.

Type of site.--Miscellaneous site.

Discharge measurement.--Aug. $20,1970,0.26 \mathrm{ft}^{3} / \mathrm{s}$.

Low-flow frequency. $-Q_{7,2}=0.28 \mathrm{ft}^{3} / \mathrm{s}, Q_{7,10}=0.15 \mathrm{ft}^{3} / \mathrm{s}$.

Basis of estimate. --Used regression equations 6 and 8 .

Accuracy. $--\mathrm{SE}_{7,2}=16$ percent, $\mathrm{SE}_{7,10}=22$ percent.

05382200 French Creek near Ettrick, Wis.

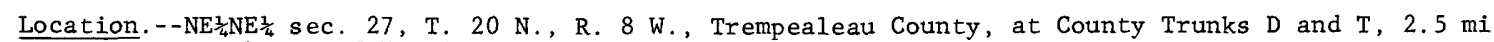
northwest of Ettrick.

Drainage area. $--14.5 \mathrm{mi}^{2}$. Tributary to.--Beaver Creek.

Type of site.--Low-flow partial-record station.

Minimum discharge measured. $--2.18 \mathrm{ft}^{3} / \mathrm{s}$, Aug. 19, 1964.

Low-flow frequency. $-Q_{7,2}=3.7 \mathrm{ft}^{3} / \mathrm{s}, Q_{7,10}=2.3 \mathrm{ft}^{3} / \mathrm{s}$.

Basis of estimate.--Correlated with Trempealeau River at Dodge using 23 discharge measurements made during the period 1961-70.

Accuracy.--SE $7,2=5$ percent, $\mathrm{SE}_{7,10}=7$ percent.

05382202 French Creek near Ettrick, Wis.

Location.--SW $\frac{1}{4} \mathrm{SE}_{\frac{1}{4}} \mathrm{sec} .27$, T. $20 \mathrm{~N} .$, R. 8 W., Trempealeau County, at bridge on country road, $2.6 \mathrm{mi}$ west of Ettrick.

Drainage area. $--15.9 \mathrm{mi}^{2}$.

Tributary to. --Beaver Creek.

Type of site.--Miscellaneous site.

Discharge measurement. --Aug. 20, 1970, $4.97 \mathrm{ft}^{3} / \mathrm{s}$.

Low-flow frequency. $-Q_{7,2}=4.2 \mathrm{ft}^{3} / \mathrm{s}, Q_{7,10}=2.9 \mathrm{ft}^{3} / \mathrm{s}$.

Basis of estimate.--Used regression equations 6 and 8 .

Accuracy.--SE $7,2=16$ percent, $\mathrm{SE}_{7,10}=22$ percent.

05382204 French Creek tributary near Ettrick, Wis.

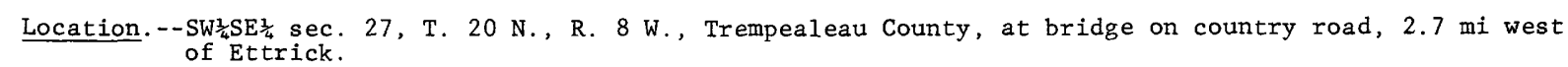

Drainage area. $--2.42 \mathrm{mi}^{2}$.

Tributary to.--French Creek.

Type of site.--Miscellaneous site.

Discharge measurement.--Aug. $20,1970,0.45 \mathrm{ft}^{3} / \mathrm{s}$.

Low-flow frequency. $-Q_{7,2}=0.43 \mathrm{ft}^{3} / \mathrm{s}, Q_{7,10}=0.25 \mathrm{ft}^{3} / \mathrm{s}$.

Basis of estimate. --Used regression equations 6 and 8 .

Accuracy. - $-\mathrm{SE}_{7,2}=16$ percent, $\mathrm{SE}_{7,10}=22$ percent. 
Table 1.--Low-flow characteristics for sites in the Trempealeau-Black River basin--Continued

05382206 French Creek near Ettrick, Wis.

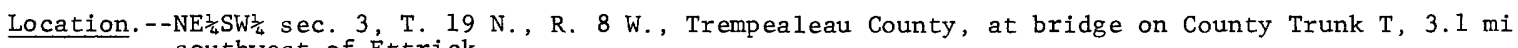
southwest of Ettrick.

Drainage area. $--21.9 \mathrm{mi}^{2}$. Tributary to. --Beaver Creek.

Type of site.--Miscellaneous site.

Discharge measurement.--Aug. 20, 1970, $6.44 \mathrm{ft}^{3} / \mathrm{s}$.

Low-flow frequency. $-Q_{7,2}=5.6 \mathrm{ft}^{3} / \mathrm{s}, Q_{7,10}=3.9 \mathrm{ft}^{3} / \mathrm{s}$.

Basis of estimate. - Used regression equations 6 and 8 .

Accuracy. $--\mathrm{SE}_{7,2}=16$ percent, $\mathrm{SE}_{7,10}=22$ percent.

05382209 Beaver Creek near Galesville, Wis.

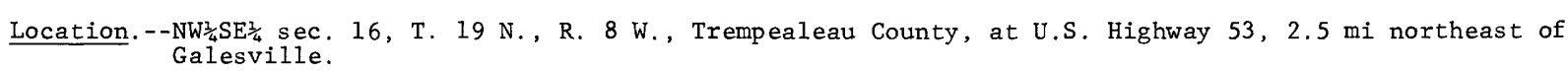

Drainage area. $--124 \mathrm{mi}^{2}$.

Tributary to. --Black River.

Type of site.--Miscellaneous site.

Discharge measurement. --Aug. $11,1970,39.0 \mathrm{ft}^{3} / \mathrm{s}$.

Low-flow frequency. $-Q_{7,2}=33 \mathrm{ft}^{3} / \mathrm{s}, Q_{7,10}=25 \mathrm{ft}^{3} / \mathrm{s}$.

Basis of estimate. --Used regression equations 6 and 8 .

Accuracy. $--\mathrm{SE}_{7,2}=16$ percent, $\mathrm{SE}_{7,10}=22$ percent.

05382211 Beaver Creek at Galesville, Wis.

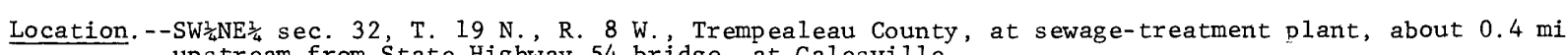
upstream from State Highway 54 bridge, at Galesville.

Drainage area. $--147 \mathrm{mi}^{2}$.

Tributary to. --Black River.

Type of site.--Miscellaneous site.

Minimum discharge measured. $--53.0 \mathrm{ft}^{3} / \mathrm{s}$, Sept. 2, 1976.

Low-flow frequency. - $-Q_{7,2}=41 \mathrm{ft}^{3} / \mathrm{s}, Q_{7,10}=29 \mathrm{ft}^{3} / \mathrm{s}$.

Basis of estimate.--Correlated with Trempealeau River at Dodge using 8 discharge measurements made during the period 1972-76.

Accuracy.--SE $7,2=13$ percent, $\mathrm{SE}_{7,10}=15$ percent.

05382237 Halfway Creek at Holmen, Wis.

Location. - - $\mathrm{NW}_{\frac{1}{4}} \mathrm{SE}_{\frac{1}{4}} \mathrm{sec} .7, \mathrm{~T} .17 \mathrm{~N}, \mathrm{R} .7 \mathrm{~W} .$, La Crosse County, at sewage-treatment plant, $0.4 \mathrm{mi}$ downstream from County Trunk DH, in Holmen.

Drainage area. $--31.1 \mathrm{mi}^{2}$.

Tributary to.--Mississippi River.

Type of site.--Miscellaneous site.

Minimum discharge measured. $--7.31 \mathrm{ft}^{3} / \mathrm{s}$, Aug. 9, 1973.

Low-flow frequency. $-Q_{7,2}=5.1 \mathrm{ft}^{3} / \mathrm{s}, Q_{7,10}=3.1 \mathrm{ft}^{3} / \mathrm{s}$.

Basis of estimate.--Correlated with Trempealeau River at Dodge using 9 discharge measurements made during the period 1972-77.

Accuracy. $--\mathrm{SE}_{7,2}=21$ percent, $\mathrm{SE}_{7,10}=33$ percent. 
Location. - $-\mathrm{SE} \frac{1}{4} \mathrm{SE} \frac{1}{4} \mathrm{sec} .24, \mathrm{~T} .17 \mathrm{~N} ., \mathrm{R} .8 \mathrm{~W}$, La Crosse County, at culvert on County Trunk ZN, 0.7 mi west of Midway.

Drainage area. $--34.5 \mathrm{mi}^{2}$. Tributary to.--Mississippi River.

Type of site.--Miscellaneous site.

Discharge measurement.--Aug. 12, $1970,5.89 \mathrm{ft}^{3} / \mathrm{s}$.

Low-flow frequency. $-Q_{7,2}=5.8 \mathrm{ft}^{3} / \mathrm{s}, Q_{7,10}=3.8 \mathrm{ft}^{3} / \mathrm{s}$.

Basis of estimate.--Used regression equations 6 and 8 .

Accuracy. $--\mathrm{SE}_{7,2}=16$ percent, $\mathrm{SE} 7,10=18$ percent.

05382265 La Crosse River near Angelo, Wis.

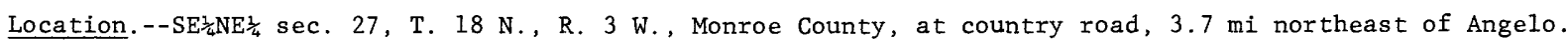
Drainage area. $--59.7 \mathrm{mi}^{2}$. Tributary to. --Mississippi River.

Type of site.--Miscellaneous site.

Discharge measurements.--Aug. 13, 1970, $58.3 \mathrm{ft}^{3} / \mathrm{s} ;$ Aug. 10, 1972, 60.5 $\mathrm{ft}^{3} / \mathrm{s} ; \mathrm{June} 27,1973,103 \mathrm{ft} / \mathrm{s}$; Sept. 11, 1973, $72 \mathrm{ft} 3 / \mathrm{s}$; Aug. 19, 1976, 46.2 $\mathrm{ft}^{3} / \mathrm{s}$.

Low-flow frequency. $--Q_{7,2}=41 \mathrm{ft}^{3} / \mathrm{s}, Q_{7,10}=31 \mathrm{ft}^{3} / \mathrm{s}$.

Basis of estimate.--Correlated with Trempealeau River at Dodge using 5 discharge measurements.

Accuracy. $--\mathrm{SE}_{7,10}=19$ percent (basin average).

05382280 Silver Creek near Sparta, Wis.

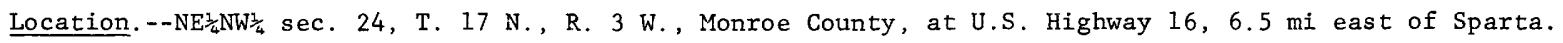
Drainage area. $--14.7 \mathrm{mi}^{2}$. Tributary to. --La Crosse River.

Type of site.--Low-flow partial-record station.

Minimum discharge measured. $--5.77 \mathrm{ft}^{3} / \mathrm{s}$, Aug. 17, 1964.

Low-flow frequency. $-Q_{7,2}=6.6 \mathrm{ft}^{3} / \mathrm{s}, Q_{7,10}=5.6 \mathrm{ft}^{3} / \mathrm{s}$.

Basis of estimate.--Correlated with Little La Crosse River near Leon using 10 discharge measurements made during the period 1964-77.

Accuracy. $-\mathrm{SE}_{7,2}=4$ percent, $S E_{7,10}=7$ percent.

05382330 La Crosse River at Sparta, Wis.

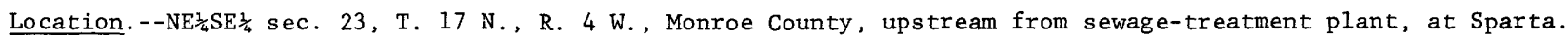
Drainage area. $-168 \mathrm{mi}^{2}$. Tributary to. - -Mississippi River.

Type of site.--Miscellaneous site.

Discharge measurements.--June $27,1973,223 \mathrm{ft}^{3} / \mathrm{s} ;$ Sept. $11,1973,178 \mathrm{ft} / \mathrm{s} ; \mathrm{Aug} .18,1976,104 \mathrm{ft} / \mathrm{s}$; Aug. $8,1977,104 \mathrm{ft} 3 / \mathrm{s}$.

Low-flow frequency. $--Q_{7,2}=84 \mathrm{ft}^{3} / \mathrm{s}, Q_{7,10}=63 \mathrm{ft}^{3} / \mathrm{s}$.

Basis of estimate.--Correlated with Trempealeau River at Dodge using 4 discharge measurements.

Accuracy. $--\mathrm{SE}_{7,10}=19$ percent (basin average). 
05382380 Little La Crosse River at Cashton, Wis.

Location.-- $\begin{gathered}-\mathrm{NW} \frac{1}{4} \mathrm{NE} \frac{1}{4} \mathrm{sec} .24, \mathrm{~T} .15 \mathrm{~N} ., \text { R. } 4 \mathrm{~W} ., \text { Monroe County, at bridge on State Highway } 27,1.8 \mathrm{mi} \\ \text { northwest of Cashton. }\end{gathered}$

Drainage area. $--3.05 \mathrm{mi}^{3}$. Tributary to. --La Crosse River.

Type of site.--Miscellaneous site.

Discharge measurements.--Aug. 10, 1972, $0.78 \mathrm{ft}^{3} / \mathrm{s} ;$ June $28,1973,2.03 \mathrm{ft} / \mathrm{s} ; \mathrm{Sept} .11,1973,2.22 \mathrm{ft} / \mathrm{s}$; Aug. $18,1976,0.92 \mathrm{ft}^{3} / \mathrm{s}$.

Low-flow frequency. $-Q_{7,2}=0.53 \mathrm{ft}^{3} / \mathrm{s}, Q_{7,10}=0.38 \mathrm{ft}^{3} / \mathrm{s}$.

Basis of estimate.--Correlated with Kickapoo River at La Farge using 4 discharge measurements.

Accuracy. $-\mathrm{SE}_{7,10}=19$ percent (basin average).

05382410 Little La Crosse River at Melvina, Wis.

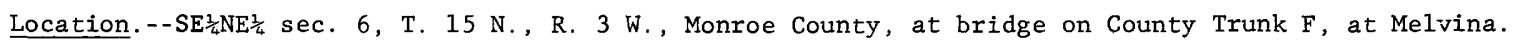

Drainage area. $--18.4 \mathrm{mi}^{2}$.

Tributary to.--La Crosse River.

Type of site.--Miscellaneous site.

Discharge measurements.--Aug. 10, 1972, $6.37 \mathrm{ft}^{3} / \mathrm{s} ;$ June $28,1973,12.3 \mathrm{ft} / \mathrm{s} ; \mathrm{Sept} .11,1973,12.7 \mathrm{ft} / \mathrm{s}$; Aug. 18, $1976,4.80 \mathrm{ft}^{3} / \mathrm{s}$.

Low-flow frequency. $-\mathrm{Q}_{7,2}=3.7 \mathrm{ft}^{3} / \mathrm{s}, \mathrm{Q}_{7,10}=2.7 \mathrm{ft}^{3} / \mathrm{s}$.

Basis of estimate.--Correlated with Kickapoo River at La Farge using 4 discharge measurements.

Accuracy. $--\mathrm{SE}_{7,10}=19$ percent (basin average).

05382500 Little La Crosse River near Leon, Wis.

Location. $-\mathrm{NE}_{\frac{1}{4}} \mathrm{NW}_{\frac{1}{4}} \mathrm{sec} .3$, T. $16 \mathrm{~N} .$, R. $4 \mathrm{~W}$, Monroe County, at town road, $1.5 \mathrm{mi}$ northwest of Leon.

Drainage area. $-77.1 \mathrm{mi}^{2}$. Tributary to.--La Crosse River.

Type of site.--Gaging station and low-flow partial-record station.

Period of record.--March 1934 to September 1961.

Average discharge. --27 years, $46.3 \mathrm{ft}^{3} / \mathrm{s}$.

Extremes.--Maximum discharge, 4,620 $\mathrm{ft}^{3} / \mathrm{s}$ Aug. 6, 1935 ; minimum daily, $18 \mathrm{ft} / \mathrm{s} \mathrm{June} 2$ and 3,1934 .

\begin{tabular}{l|cccccc|}
\hline $\begin{array}{l}\text { Period } \\
\text { of con- } \\
\text { secutive } \\
\text { days }\end{array}$ & $\begin{array}{l}\text { Magnitude and frequency of annual low flow } \\
\text { Discharge, in cubic feet per second, for } \\
\text { indicated recurrence interval, in years }\end{array}$ \\
\hline & 2 & 5 & 10 & 20 & 50 & 100 \\
& 27 & 23 & 22 & 20 & 19 & 18 \\
7 & 28 & 24 & 22 & 21 & 19 & 18 \\
14 & 29 & 25 & 23 & 22 & 20 & 19 \\
30 & 31 & 27 & 25 & 23 & 22 & 20 \\
60 & 33 & 28 & 26 & 25 & 23 & 22 \\
90 & & & & & & \\
\hline
\end{tabular}

\begin{tabular}{|l|rrrrrrr|}
\hline \multicolumn{7}{|c|}{ Duration table of daily flow } \\
Discharge, in cubic feet per second, which \\
was exceeded for indicated percent of time \\
\hline $\begin{array}{l}\text { Percent } \\
\mathrm{ft} \mathrm{t}^{3 / \mathrm{s}}\end{array}$ & 155 & 5 & 10 & 20 & 30 & 40 & 50 \\
\hline Percent & 60 & 70 & 80 & 90 & 95 & 98 & 99.9 \\
$\mathrm{ft} / \mathrm{s}$ & 36 & 33 & 31 & 28 & 26 & 24 & 21 \\
\hline
\end{tabular}

Accuracy. $--\mathrm{SE}_{7,2}=3$ percent, $S E_{7,10}=5$ percent. 
05382560 La Crosse River at Rockland, Wis.

Location.--NW $\frac{3}{4} \mathrm{NE}_{\frac{1}{4}} \mathrm{sec} .36$, T. $17 \mathrm{~N} .$, R. 5 W., La Crosse County, County Trunk J, $0.5 \mathrm{mi}$ north of Rockland. Drainage area. $--285 \mathrm{mi}^{2}$. Tributary to.--Mississippi River.

Type of site.--Miscellaneous site.

Discharge measurements. --Aug. $13,1970,178 \mathrm{ft}^{3} / \mathrm{s}$; Aug. $10,1972,195 \mathrm{ft}^{3} / \mathrm{s}$; June $26,1973,338 \mathrm{ft}^{3} / \mathrm{s}$; Sept. 11, $1973,236 \mathrm{ft} 3 / \mathrm{s}$; Aug. $18,1976,167 \mathrm{ft}^{3} / \mathrm{s}$.

Low-flow frequency. $-Q_{7,2}=120 \mathrm{ft}^{3} / \mathrm{s}, Q_{7,10}=87 \mathrm{ft}^{3} / \mathrm{s}$.

Basis of estimate.--Correlated with Trempealeau River at Dodge using 5 discharge measurements.

Accuracy. $--\mathrm{SE}_{7,10}=19$ percent (basin average).

05382590 Dutch Creek at Bangor, Wis.

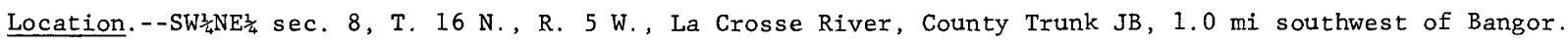
Drainage area. $--17.0 \mathrm{mi}^{2}$. Tributary to. --La Crosse River.

Type of site.--Miscellaneous site.

Discharge measurement. --Aug. 12, $1970,9.16 \mathrm{ft}^{3} / \mathrm{s}$.

Low-flow frequency. $-Q_{7,2}=7.1 \mathrm{ft}^{3} / \mathrm{s}, Q_{7,10}=5.3 \mathrm{ft}^{3} / \mathrm{s}$.

Basis of estimate.--Used regression equations 6 and 8 .

Accuracy. $--\mathrm{SE}_{7,2}=16$ percent, $\mathrm{SE}_{7,10}=22$ percent.

05382610 La Crosse River at Bangor, Wi.

Location.-- $\mathrm{SE}_{\frac{1}{4} \mathrm{SE}} \mathrm{sec}$. 32 , T. $17 \mathrm{~N} .$, R. 5 W., La Crosse County, just downstream from Dutch Creek, $0.6 \mathrm{mi}$ Drainage area. $--332 \mathrm{mi}^{2}$. Tributary to. --Mississippi River.

Type of site.--Miscellaneous site.

Discharge measurements. --Aug. 18, 1976, $192 \mathrm{ft}^{3} / \mathrm{s}$; Aug. 8, 1977, $191 \mathrm{ft}^{3} / \mathrm{s}$; Sept. 13, 1977, $172 \mathrm{ft}^{3} / \mathrm{s}$; Sept. 11, $1978,210 \mathrm{ft}^{3} / \mathrm{s}$.

Low-flow frequency. $-Q_{7,2}=140 \mathrm{ft}^{3} / \mathrm{s}, Q_{7,10}=100 \mathrm{ft}^{3} / \mathrm{s}$.

Basis of estimate.--Correlated with La Crosse River near West Salem using 4 discharge measurements.

Accuracy. $--\mathrm{SE}_{7,10}=19$ percent (basin average). 
05383000 La Crosse River near West Salem, Wis.

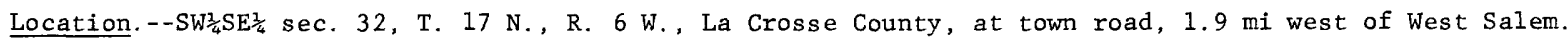
Drainage area. $--398 \mathrm{mi}^{2}$. Tributary to. --Mississippi River.

Type of site.--Gaging station.

Period of record.--December 1913 to September 1970.

Average discharge. --56 years, $288 \mathrm{ft}^{3} / \mathrm{s}$.

Extremes.--Maximum discharge, 8,200 ft $\mathrm{ft}^{3} / \mathrm{s}$ Aug. 6, 1935; minimum discharge, $30 \mathrm{ft}^{3} / \mathrm{s}$ Sept. $5,1948$.

\begin{tabular}{|r|rrrrrr|}
\hline $\begin{array}{l}\text { Period } \\
\text { of con- } \\
\text { secutive } \\
\text { days }\end{array}$ & \multicolumn{2}{|c|}{$\begin{array}{l}\text { Magnitude and frequency of annual low flow } \\
\text { Discharge, in cubic feet per second, for } \\
\text { indicated recurrence interval, in years }\end{array}$} \\
\hline & 2 & 5 & 10 & 20 & 50 & 100 \\
\cline { 2 - 7 } & 160 & 131 & 116 & 104 & 92 & 83 \\
7 & 166 & 141 & 130 & 121 & 111 & 105 \\
14 & 178 & 156 & 145 & 137 & 129 & 124 \\
30 & 203 & 178 & 158 & 150 & 141 & 136 \\
60 & 162 & 156 & 148 & 140 \\
90 & & & & &
\end{tabular}

\begin{tabular}{|c|c|c|c|c|c|c|c|}
\hline $\begin{array}{l}\text { Discharg } \\
\text { was exc }\end{array}$ & $\begin{array}{l}\text { rati } \\
\text { in } \\
\text { ded }\end{array}$ & $\begin{array}{l}\text { tal } \\
\text { cubi } \\
\text { or in }\end{array}$ & $\begin{array}{l}\text { e o } \\
\text { fee } \\
\text { lica }\end{array}$ & $\begin{array}{l}\text { dail } \\
\text { per } \\
\text { ed pe }\end{array}$ & $\begin{array}{l}\text { flo } \\
\text { secon } \\
\text { ecent }\end{array}$ & of & $\begin{array}{l}\text { ch } \\
\text { me }\end{array}$ \\
\hline Percent & 2 & 5 & 10 & 20 & 30 & 40 & 50 \\
\hline$f t^{3} / s$ & 845 & 560 & 410 & 323 & 290 & 267 & 248 \\
\hline Percent & 60 & 70 & 80 & 90 & 95 & 98 & 99.9 \\
\hline $\mathrm{ft}^{3} / \mathrm{s}$ & 229 & 210 & 190 & 172 & 159 & 140 & 85 \\
\hline
\end{tabular}

Accuracy. $-\mathrm{SE}_{7,2}=3$ percent, $\mathrm{SE}_{7,10}=5$ percent.

Remarks.--Occasional fluctuation caused by powerplant upstream.

05383029 St. Joseph Coulee tributary at St. Joseph, Wis.

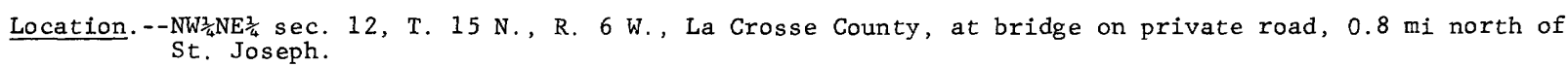
Drainage area. $--0.49 \mathrm{mi}^{2}$. Tributary to.--St. Joseph Coulee.

Type of site.--Miscellaneous site.

Discharge measurements. - Aug. $18,1976,0.39 \mathrm{ft}^{3} / \mathrm{s} ;$ Aug. $9,1977,0.28 \mathrm{ft}^{3} / \mathrm{s} ;$ Sept. 13, $1977,0.36 \mathrm{ft}^{3} / \mathrm{s}$; Low-flow frequency. $-0_{7,2}=0.17 \mathrm{ft}^{3} / \mathrm{s}, Q_{7,10}=0.13 \mathrm{ft}^{3} / \mathrm{s}$.

Basis of estimate.--Correlated with Coon Creek at Coon Valley using 4 discharge measurements. Accuracy.-- $-\mathrm{SE}_{7,10}=19$ percent (basin average).

05383050 Bostwick Creek near Barre Mills, Wis.

Location. - - SW $\frac{1}{4} \mathrm{NW}_{\frac{1}{4}} \mathrm{sec} .17$, T. $16 \mathrm{~N}$., R. 6 W., La Crosse County, at bridge on County Trunk B, $1.7 \mathrm{mi}$ northwest of Barre Mills.

Drainage area. $--41.5 \mathrm{mi}^{2}$.

Tributary to. --La Crosse River.

Type of site.--Miscellaneous site.

Discharge measurement.--Aug. $12,1970,14.5 \mathrm{ft}^{3} / \mathrm{s}$.

Low-flow frequency. $-Q_{7,2}=13 \mathrm{ft}^{3} / \mathrm{s}, Q_{7,10}=9.7 \mathrm{ft} / \mathrm{s}$.

Basis of estimate. - Used regression equations 6 and 8 .

Accuracy. $--\mathrm{SE}_{7,2}=16$ percent, $\mathrm{SE}_{7,10}=22$ percent. 
05386300 Mormon Creek near La Crosse, Wis.

Location. - - NE $\frac{1}{4} \mathrm{NW} \frac{1}{4} \mathrm{sec} .19$, T. $15 \mathrm{~N} .$, R. $6 \mathrm{~W}$., La Crosse County, at bridge on country road, 6.4 mi southeast

Drainage area. $--25.5 \mathrm{mi}^{2}$. Tributary to.--Mississippi River.

Type of site.--Low-flow partial-record station.

Minimum discharge measured. $--8.85 \mathrm{ft}^{3} / \mathrm{s}$, Oct. 20, 1964.

Low-flow frequency. $-Q_{7,2}=9.6 \mathrm{ft}^{3} / \mathrm{s}, Q_{7,10}=8.4 \mathrm{ft}^{3} / \mathrm{s}$. Basis of estimate.-- Correlated with Little La Crosse River near Leon using 25 discharge measurements made
during the period 1961-70.

Accuracy. $--\mathrm{SE}_{7,2}=6$ percent, $\mathrm{SE}_{7,10}=7$ percent.

05386500 Coon Creek at Coon Valley, Wis.

Location.--SW/4NE⿺ sec. 7, T. 14 N., R. 5 W., Vernon County, 700 ft upstream from U.S. Highways 14 and 61 , at
Coon Valley. Drainage area. $--78.6 \mathrm{mi}^{2}$. Tributary to.--Mississippi River.

Type of site.--Gaging station.

Period of record.--April 1934 to September 1940.

Average discharge. --6 years, $41 \mathrm{ft}^{3} / \mathrm{s}$.

Extremes.--Maximum discharge, 8,110 $\mathrm{ft}^{3} / \mathrm{s}$ Aug. 6, 1935; minimum daily discharge, $21 \mathrm{ft} / \mathrm{s}$ Aug. 26,1934 .

\begin{tabular}{|c|c|c|c|c|}
\hline $\begin{array}{l}\text { Period } \\
\text { of con- } \\
\text { secutive } \\
\text { days }\end{array}$ & \multicolumn{4}{|c|}{$\begin{array}{l}\text { Magnitude and frequency of annual low flow } \\
\text { Discharge, in cubic feet per second, for } \\
\text { indicated recurrence interval, in years }\end{array}$} \\
\hline & 2 & 5 & 10 & 20 \\
\hline $\begin{array}{r}7 \\
14 \\
30 \\
60 \\
90\end{array}$ & $\begin{array}{l}28 \\
29 \\
30 \\
32 \\
33\end{array}$ & $\begin{array}{l}25 \\
26 \\
27 \\
28 \\
30\end{array}$ & $\begin{array}{l}24 \\
25 \\
25 \\
27 \\
28\end{array}$ & $\begin{array}{l}23 \\
23 \\
24 \\
25 \\
26\end{array}$ \\
\hline
\end{tabular}

Accuracy. $--\mathrm{SE}_{7,2}=2$ percent, $\mathrm{SE}_{7,10}=3$ percent.

Remarks.--The frequency analyses for the 7-, 14-, 30-, 60-, and 90-day low flows are based on the extension of records with 05382500 Little La Crosse River near Leon (1935-61 CY). All correlation coefficients are greater than 0.97 .

05386850 Coon Creek at Chaseburg, Wis.

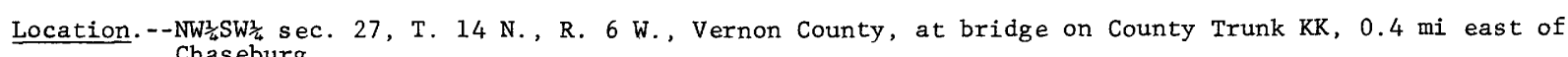
Chas eburg.

Drainage area. $--105 \mathrm{mi}^{2}$. Tributary to.--Mississippi River.

Type of site. -Miscellaneous site.

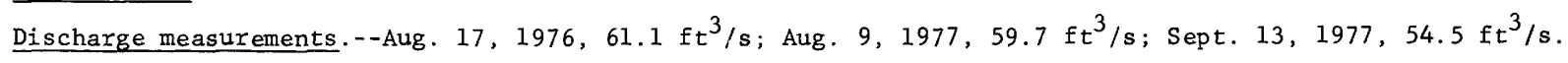
Low-flow frequency. $-Q_{7,2}=39 \mathrm{ft}^{3} / \mathrm{s}, Q_{7,10}=34 \mathrm{ft}^{3} / \mathrm{s}$.

Basis of estimate.--Correlated with Coon Creek at Coon Valley using 3 discharge measurements.

Accuracy. $--\mathrm{SE}_{7,10}=19$ percent (basin average). 
Location. - $-\mathrm{NW}_{4}^{\frac{1}{4}} \mathrm{NE} \frac{1}{4} \mathrm{sec} .33$, T. $14 \mathrm{~N} .$, R. $6 \mathrm{~W}$, Vernon County, 0.3 mi upstream from mouth, at Chaseburg. Drainage area. $--1.35 \mathrm{mi}^{2}$. Tributary to.--Coon Creek.

Type of site.--Miscellaneous site.

Discharge measurement.--Aug. 17, 1976, $0 \mathrm{ft}^{3} / \mathrm{s}$.

Low-flow frequency. $--Q_{7,2}=0 \mathrm{ft}^{3} / \mathrm{s}, Q_{7,10}=0 \mathrm{ft}^{3} / \mathrm{s}$.

Basis of estimate.--Used regression equations 6 and 8 .

Accuracy.--Not applicable.

05387000 Coon Creek near Stoddard, Wis.

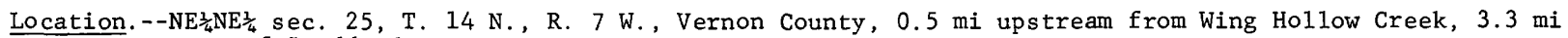
east of Stoddard.

Drainage area. $--119 \mathrm{mi}^{2}$.

Tributary to.--Mississippi River.

Type of site.--Gaging station.

Period of record. --April 1934 to September 1940.

Average discharge. --6 years, $68.2 \mathrm{ft}^{3} / \mathrm{s}$.

Extremes.--Maximum discharge, 5,160 ft $\mathrm{ft}^{3} / \mathrm{s}$ Aug. 6, 1935 ; minimum daily discharge, $31 \mathrm{ft} / \mathrm{s}$ Dec 23,1937 .

\begin{tabular}{|c|c|c|c|c|}
\hline $\begin{array}{l}\text { Period } \\
\text { of con- } \\
\text { secutive } \\
\text { days }\end{array}$ & \multicolumn{4}{|c|}{$\begin{array}{l}\text { Magnitude and frequency of annual low flow } \\
\text { Discharge, in cubic feet per second, for } \\
\text { indicated recurrence interval, in years }\end{array}$} \\
\hline & 2 & 5 & 10 & 20 \\
\hline $\begin{array}{r}7 \\
14 \\
30 \\
60 \\
90\end{array}$ & $\begin{array}{l}45 \\
47 \\
50 \\
53 \\
55\end{array}$ & $\begin{array}{l}42 \\
43 \\
45 \\
47 \\
49\end{array}$ & $\begin{array}{l}40 \\
41 \\
42 \\
44 \\
46\end{array}$ & $\begin{array}{l}39 \\
39 \\
40 \\
42 \\
44\end{array}$ \\
\hline
\end{tabular}

Accuracy. $-\mathrm{SE}_{7,2}=2$ percent, $\mathrm{SE}_{7,10}=3$ percent.

Remarks.--Slight diurnal fluctuation caused by grist mil1 4 mi upstream from station. The frequency analyses for the 7-, 14-, 30-, 60-, and 90-day low flows are based on extension of records with 05382900 Littlé La Crossé River near Leon (1935-61 CY). All correlation coefficients are greater than 0.96 .

05387005 Coon Creek near Stoddard, Wis.

Location.--SW $\frac{1}{4}$ SW $\frac{3}{4}$ sec. 25, T. 14 N., R. 7 W., Vernon County, at country road, 2.7 mi east of Stoddard.

Drainage area. $--125 \mathrm{mi}^{2}$.

Tributary to.--Mississippi River.

Type of site.--Miscellaneous site.

Discharge measurement.--Aug. $11,1970,65.8 \mathrm{ft}^{3} / \mathrm{s}$.

Low-flow frequency. $-Q_{7,2}=50 \mathrm{ft}^{3} / \mathrm{s}, Q_{7,10}=42 \mathrm{ft}^{3} / \mathrm{s}$.

Basis of estimate.--Used regression equations 6 and 8 .

Accuracy. $--\mathrm{SE}_{7,2}=16$ percent, $\mathrm{SE}_{7,10}=22$ percent. 
05387072 North Fork Bad Axe River near Westby, Wis.

Location. --SW $\frac{1}{4} \mathrm{SW}_{\frac{1}{4}} \mathrm{sec} .29$, T. $14 \mathrm{~N} .$, R. 4 W., Vernon County, at bridge on country road, $1.6 \mathrm{mi}$ west of Westby. Drainage area. $--1.77 \mathrm{mi}^{2}$. Tributary to. - -Bad Axe River.

Type of site.--Miscellaneous site.

Discharge measurements.--June 20,1972, $0 \mathrm{ft}^{3} / \mathrm{s}$; Sept. 11, 1973, $0 \mathrm{ft}^{3} / \mathrm{s}$; Aug. 16, 1976, $0 \mathrm{ft}^{3} / \mathrm{s}$.

Low-flow frequency. $-Q_{7,2}=0.00 \mathrm{ft}^{3} / \mathrm{s}, Q_{7,10}=0.00 \mathrm{ft}^{3} / \mathrm{s}$.

Basis of estimate.--Correlated with Coon Creek at Coon Valley using 3 discharge measurements.

Accuracy. --Not applicable.

05387085 Springville Branch at Viroqua, Wis.

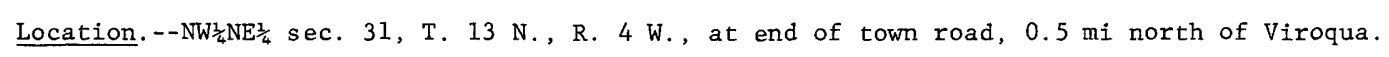

Drainage area. $--1.15 \mathrm{mi}^{2}$.

Tributary to.--Bad Axe River.

Type of site.--Miscellaneous site.

Discharge measurements.--June 20, 1972, $0.64 \mathrm{ft}_{3}^{3} / \mathrm{s} ;$ June $28,1973,0.71 \mathrm{ft}^{3} / \mathrm{s} ;$ Sept. 13, 1973, $0.78 \mathrm{ft}^{3} / \mathrm{s}$; Aug. 16, 1976, $052 \mathrm{ft}^{3} / \mathrm{s}$.

Low-flow frequency. $-Q_{7,2}=0.47 \mathrm{ft}^{3} / \mathrm{s}, Q_{7,10}=0.28 \mathrm{ft}^{3} / \mathrm{s}$.

Basis of estimate.--Correlated with Nederlo Creek near Gays Mills using 4 discharge measurements.

Accuracy. $--\mathrm{SE}_{7,10}=19$ percent (basin average).

05387087 Springville Branch tributary near Viroqua, Wis.

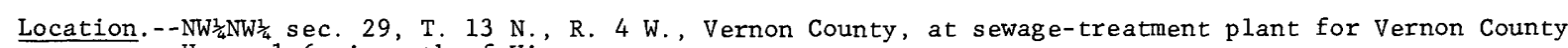
Home, $1.6 \mathrm{mi}$ north of Viroqua.

Drainage area. $--0.31 \mathrm{mi}^{2}$.

Tributary to.--Springville Branch.

Type of site.--Miscellaneous site.

Discharge measurement.--June 20, 1972, $0 \mathrm{ft}^{3} / \mathrm{s}$.

Low-flow frequency. $-Q_{7,2}=0 \mathrm{ft}^{3} / \mathrm{s}, Q_{7,10}=0 \mathrm{ft}^{3} / \mathrm{s}$.

Basis of estimate.--Used regression equations 6 and 8 .

Accuracy. --Not applicable.

05387090 Springville Branch at Springville, Wis.

Location. - - SW $\frac{1}{4} \mathrm{SE}_{\frac{1}{4}} \mathrm{sec} .23$, T. $13 \mathrm{~N}$., R. 5 W., Vernon County, at bridge on County Trunk B, in Springville. Drainage area. $--8.93 \mathrm{mi}^{2}$. Tributary to. --Bad Axe River.

Type of site.--Miscellaneous site.

Discharge measurements.--June 20, 1972, 2.57 $\mathrm{ft}_{3}^{3} / \mathrm{s} ;$ June $28,1973,6.02 \mathrm{ft}^{3} / \mathrm{s} ;$ Sept. 13, $1973,5.61 \mathrm{ft} / \mathrm{s} ;$ June $29,1976,4.54 \mathrm{ft}_{\mathrm{t}} / \mathrm{s}$; Aug. 16, 1976, $3.91 \mathrm{ft} / \mathrm{s}$.

Low-flow frequency. $-Q_{7,2}=2.6 \mathrm{ft}^{3} / \mathrm{s}, Q_{7,10}=1.1 \mathrm{ft}^{3} / \mathrm{s}$.

Basis of estimate.--Correlated with Nederlo Creek near Gays Mills using 5 discharge measurements.

Accuracy. - $-\mathrm{SE}_{7,10}=19$ percent (basin average). 
05387100 North Fork Bad Axe River near Genoa, Wis.

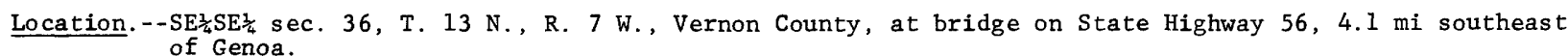

Drainage area. $--80.9 \mathrm{mi}^{2}$. Tributary to. --Mississippi River.

Type of site.--Low-flow partial-record station.

Minimum discharge measured. $--22.9 \mathrm{ft}^{3} / \mathrm{s}$, Aug. 11, 1964.

Low-flow frequency. $-Q_{7,2}=25 \mathrm{ft}^{3} / \mathrm{s}, Q_{7,10}=19 \mathrm{ft}^{3} / \mathrm{s}$.

Basis of estimate.-- Correlated with Little La Crosse River near Leon using 12 discharge measurements made Accuracy. $--\mathrm{SE}_{7,2}=16$ percent, $\mathrm{SE}_{7,10}=17$ percent.

05387130 South Fork Bad Axe River near Genoa, Wis.

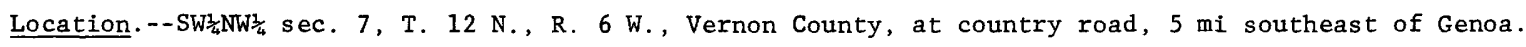

Drainage area. $--83.1 \mathrm{mi}^{2}$. Tributary to. --Bad Axe River.

Type of site.--Miscellaneous site.

Discharge measurement.--Aug. $11,1970,35.7 \mathrm{ft}^{3} / \mathrm{s}$.

Low-flow frequency. $--Q_{7,2}=30 \mathrm{ft}^{3} / \mathrm{s}, Q_{7,10}=24 \mathrm{ft}^{3} / \mathrm{s}$.

Basis of estimate. - Used regression equations 6 and 8 .

Accuracy.- $-\mathrm{SE}_{7,2}=16$ percent, $\mathrm{SE}_{7,10}=22$ percent.

05388370 Rush Creek near Ferryville, Wis.

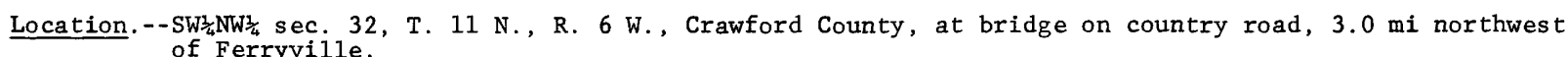
Drainage area, $--44.8 \mathrm{mi}^{2}$. Tributary to.--Mississippi River.

Type of site.--Low-flow partial-record stations.

Minimum discharge measured. $--13.8 \mathrm{ft}^{3} / \mathrm{s}$, Sept. 6, 1967.

Low-flow frequency. $-Q_{7,2}=13 \mathrm{ft}^{3} / \mathrm{s}, Q_{7,10}=8.4 \mathrm{ft}^{3} / \mathrm{s}$.

Basis of estimate.--Correlated with Knapp Creek near Bloomingdale using 9 discharge measurements made during the period 1963-76.

Accuracy. $-\mathrm{SE}_{7,2}=16$ percent, $\mathrm{SE}_{7,10}=21$ percent.

05388372 Sugar Creek near Rising Sun, Wis.

Location.-- $\mathrm{SW}_{\frac{1}{4}} \mathrm{SE}_{\frac{1}{4}} \mathrm{sec} .32, \mathrm{~T}$. $11 \mathrm{~N} ., \mathrm{R} .5 \mathrm{~W}$, Crawford County, $0.3 \mathrm{mi}$ downstream from bridge on County Trunk C, 3.2 mi southwest of Rising Sun.

Drainage area. $--7.81 \mathrm{mi}^{2}$. Tributary to.--Mississippi River.

Type of site.--Miscellaneous site.

Discharge measurements.--Aug. 12, $1969,2.58 \mathrm{ft}^{3} / \mathrm{s} ;$ Sept. $6,1972,3.30 \mathrm{ft}^{3} / \mathrm{s}$.

Low-flow frequency. $-\mathrm{Q}_{7,2}=2.4 \mathrm{ft}^{3} / \mathrm{s}, Q_{7,10}=1.6 \mathrm{ft}^{3} / \mathrm{s}$.

Basis of estimate. --Used regression equations 6 and 8 .

Accuracy. $--\mathrm{SE}_{7,2}=16$ percent, $\mathrm{SE}_{7,10}=22$ percent. 
05388373 Sugar Creek tributary near Rising Sun, Wis.

Location. - - NW $\frac{1}{4} \mathrm{NW}_{\frac{1}{4}} \mathrm{sec} .5$, T. $10 \mathrm{~N}$, R. 5 W., Crawford County, at mouth, $3.6 \mathrm{mi}$ southwest of Rising Sun. Drainage area. $--2.40 \mathrm{mi}^{2}$. Tributary to. --Sugar Creek.

Type of site.--Miscellaneous site.

Discharge measurements.--Aug. 12, $1969,0.29 \mathrm{ft}^{3} / \mathrm{s}$; Sept. $6,1972,0.17 \mathrm{ft}^{3} / \mathrm{s}$.

Low-flow frequency. $-Q_{7,2}=0.22 \mathrm{ft}^{3} / \mathrm{s}, Q_{7,10}=0.11 \mathrm{ft}^{3} / \mathrm{s}$.

Basis of estimate.--Used regression equations 6 and 8 .

Accuracy. $--\mathrm{SE}_{7,2}=16$ percent, $\mathrm{SE}_{7,10}=22$ percent.

\section{Sugar Creek at Ferryville, Wis .}

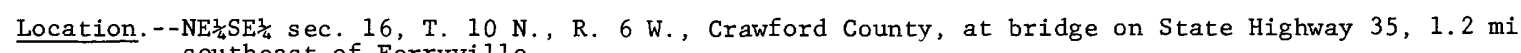
southeast of Ferryville.

Drainage area. $--24.6 \mathrm{mi}^{2}$. Tributary to. --Mississippi River.

Type of site.--Miscellaneous site.

Minimum discharge measured. $--8.40 \mathrm{ft}^{3} / \mathrm{s}$, Aug. 11, 1970.

Low-flow frequency. $--Q_{7,2}=8.4 \mathrm{ft}^{3} / \mathrm{s}, Q_{7,10}=7.2 \mathrm{ft}^{3} / \mathrm{s}$.

Basis of estimate.--Correlated with Kickapoo River at La Farge using 6 discharge measurements made during the period 1970-76.

Accuracy. $--\mathrm{SE}_{7,2}=12$ percent, $\mathrm{SE}_{7,10}=12$ percent.

05388378 North Branch Copper Creek tributary near Mt. Sterling, Wis .

Location. - - NW $\frac{1}{4} \mathrm{SW}^{\frac{1}{4}} \mathrm{sec} .22, \mathrm{~T} .10 \mathrm{~N}$, , R. $5 \mathrm{~W}$., Crawford County, $300 \mathrm{ft}$ upstream from State Highway $171,0.1 \mathrm{mi}$ upstream from mouth, $1.6 \mathrm{mi}$ northwes of Mt. Sterling.

Drainage area. $--1.24 \mathrm{mi}^{2}$. Tributary to.--North Branch Copper Creek.

Type of site.--Miscellaneous site.

Discharge measurements.--Aug. 12, 1969, $0.20 \mathrm{ft}^{3} / \mathrm{s} ;$ Sept. $6,1972,0.50 \mathrm{ft}^{3} / \mathrm{s}$.

Low-flow frequency. $--_{7,2}=0.21 \mathrm{ft}^{3} / \mathrm{s}, Q_{7,10}=0.11 \mathrm{ft}^{3} / \mathrm{s}$.

Basis of estimate.--Used regression equations 6 and 8 .

Accuracy.- $-\mathrm{SE}_{7,2}=16$ percent, $\mathrm{SE}_{7,10}=22$ percent.

05388379 Upper Copper Creek near Mt. Sterling, Wis.

Location. - $-\mathrm{SE}_{\frac{1}{4} \mathrm{NE}} \frac{1}{4} \mathrm{sec} .16, \mathrm{~T} .10 \mathrm{~N}$., R. $5 \mathrm{~W}$., Crawford County, $1.5 \mathrm{mi}$ upstream from bridge on State Highway $171,2.6 \mathrm{mi}$ nor thwest of Mt. Sterling.

Drainage area. $--2.33 \mathrm{mi}^{2}$.

Tributary to.--North Branch Copper Creek.

Type of site.--Miscellaneous site.

Discharge measurements.--Aug. 12, 1969, $0.49 \mathrm{ft}^{3} / \mathrm{s}$; Sept. 6, 1972, $0.52 \mathrm{ft}^{3} / \mathrm{s}$.

Low-flow frequency. $-Q_{7,2}=0.48 \mathrm{ft}^{3} / \mathrm{s}, Q_{7,10}=0.28 \mathrm{ft}^{3} / \mathrm{s}$.

Basis of estimate.--Used regression equations 6 and 8 .

Accuracy. $--\mathrm{SE}_{7,2}=16$ percent, $\mathrm{SE}_{7,10}=22$ percent. 
05388380 Copper Creek near Mt. Sterling, Wis.

Location. - - SW $\frac{1}{4} \mathrm{NW} \frac{1}{4}$ sec. 29, T. 10 N., R. 5 W., Crawford County, at bridge on country road, 3.6 mi west of Mt. Sterling.

Drainage area. $--14.1 \mathrm{mi}^{2}$.

Tributary to.--Mississippi River.

Type of site.--Low-flow partial-record station.

Minimum discharge measured. $--5.27 \mathrm{ft}^{3} / \mathrm{s}$, Sept. 6, 1967.

Low-flow frequency. $-Q_{7,2}=6.2 \mathrm{ft}^{3} / \mathrm{s}, Q_{7,10}=3.8 \mathrm{ft}^{3} / \mathrm{s}$. Basis of estimate.-- Correlated with Nederlo Creek near Gays Mills using 7 discharge measurements made during

Accuracy.--SE $7,2=13$ percent, $\mathrm{SE}_{7,10}=15$ percent.

05388465 Du Charme Creek near Eastman, Wis.

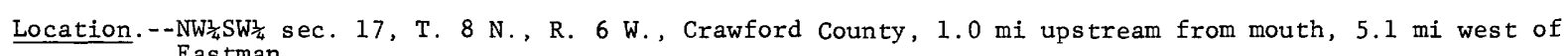
Eastman.

Drainage area. $--12.5 \mathrm{mi}^{2}$.

Tributary to.--Mississippi River.

Type of site.--Miscellaneous site.

Discharge measurement.--Aug. $11,1970,1.48 \mathrm{ft}^{3} / \mathrm{s}$.

Low-flow frequency. $-Q_{7,2}=1.7 \mathrm{ft}^{3} / \mathrm{s}, Q_{7,10}=1.0 \mathrm{ft}^{3} / \mathrm{s}$.

Basis of estimate.--Used regression equations 6 and 8 .

Accuracy. $--\mathrm{SE}_{7,2}=16$ percent, $\mathrm{SE}_{7,10}=22$ percent. 
Table 2.--Basin characteristics for low-flow partial-record stations and selected gaging stations in the Trempealeau-Black River basin

\begin{tabular}{|c|c|c|c|c|c|c|}
\hline $\begin{array}{l}\text { Station } \\
\text { number }\end{array}$ & Station name & $\begin{array}{c}\text { Drainage } \\
\text { area } \\
\left(\mathrm{mi}^{2}\right) \\
\mathrm{A}\end{array}$ & $\begin{array}{c}\text { Main-channel } \\
\text { slope } \\
\text { (ft/mi) } \\
\text { s }\end{array}$ & $\begin{array}{c}\text { Main-channel } \\
\text { length } \\
\text { (mi) } \\
\text { L }\end{array}$ & $\begin{array}{c}\text { Basin } \\
\text { storage } \\
\text { (percent) } \\
\text { Bs }\end{array}$ & $\begin{array}{c}\text { Forest } \\
\text { cover } \\
\text { (percent) } \\
\text { F }\end{array}$ \\
\hline 05378100 & $\begin{array}{l}\text { Little Waumandee Creek near } \\
\text { Cream }\end{array}$ & 46.0 & 22.3 & 17.1 & 0.00 & 42.4 \\
\hline 05378200 & $\begin{array}{l}\text { Eagle Creek near Fountain } \\
\text { City }\end{array}$ & 26.8 & 40.9 & 11.3 & .00 & 47.6 \\
\hline 05379200 & Trempealeau River at Taylor & 110 & 8.6 & 18.6 & .73 & 32.4 \\
\hline 05379300 & Elk Creek at Elk Creek & 90.1 & 11.8 & 13.0 & .31 & 12.9 \\
\hline 05380820 & $\begin{array}{l}\text { Little Black River near } \\
\text { Medford }\end{array}$ & 58 & 7.79 & 18.8 & 15.5 & 44.8 \\
\hline 05380870 & Pine Creek near Medford & 34.3 & 11.0 & 17.2 & 6.70 & 16.5 \\
\hline 05380900 & Poplar River near Owen & 157 & 7.04 & 30.2 & 4.17 & 22.2 \\
\hline 05380970 & Cawley Creek near Neillsville & 38.6 & 17.2 & 11.2 & .08 & 20.3 \\
\hline 05381150 & $\begin{array}{l}\text { East Fork Black River } \\
\text { near Pittsville }\end{array}$ & 37.2 & 9.0 & 14.7 & 4.60 & 46.2 \\
\hline 05381170 & Rock Creek near Neillsville & 27.8 & 9.3 & 11.0 & 5.70 & 53.2 \\
\hline 05381350 & $\begin{array}{l}\text { Levis Creek near Black } \\
\text { River Falls }\end{array}$ & 39.7 & 12.5 & 12.7 & 25.4 & 81.3 \\
\hline 05381450 & Big Creek near Cataract & 64.0 & 19.5 & 12.8 & .00 & 28.9 \\
\hline 05381800 & Fleming Creek at Stevenstown & 28.5 & 57.7 & 8.07 & .40 & 37.5 \\
\hline 05382100 & $\begin{array}{l}\text { South Fork Beaver Creek } \\
\text { at Ettrick }\end{array}$ & 33.1 & 14.5 & 13.4 & 1.00 & 27.5 \\
\hline 05382200 & French Creek near Ettrick & 14.5 & 33.8 & 5.70 & .00 & 26.6 \\
\hline 05382280 & Silver Creek near Sparta & 14.7 & 44.9 & 6.70 & .81 & 52.1 \\
\hline 05382500 & $\begin{array}{l}\text { Little La Crosse River } \\
\text { near Leon }\end{array}$ & 77.1 & 20.0 & 15.8 & 2.65 & 30.4 \\
\hline 05386300 & Mormon Creek near La Crosse & 25.5 & 47.5 & 9.6 & .00 & 36.0 \\
\hline 05386500 & Coon Creek at Coon Valley & 78.6 & 34.7 & 23.8 & .00 & 33.9 \\
\hline 05387000 & Coon Creek near Stoddard & 119 & 15.6 & 13.3 & .02 & 38.0 \\
\hline 05387100 & $\begin{array}{l}\text { North Fork Bad Axe River } \\
\text { near Genoa }\end{array}$ & 80.9 & 27.3 & 22.5 & .00 & 28.0 \\
\hline 05388370 & Rush River near Ferryville & 44.8 & 27.9 & 14.0 & .10 & 19.8 \\
\hline 05388380 & $\begin{array}{l}\text { Copper Creek near Mount } \\
\text { Sterling }\end{array}$ & 14.1 & 66.5 & 5.30 & .00 & 34.9 \\
\hline
\end{tabular}


Table 2.--Basin characteristics for low-flow partial-record stations and selected gaging stations in the Trempealeau-Black River basin

\begin{tabular}{|c|c|c|c|c|c|c|}
\hline $\begin{array}{l}\text { Mean annual } \\
\text { precipitation } \\
\text { (in) } \\
\text { P }\end{array}$ & $\begin{array}{c}\text { Soil infil- } \\
\text { tration } \\
\text { rate } \\
\text { (in/hr) } \\
\text { I }\end{array}$ & $\begin{array}{c}\text { Mean } \\
\text { annual } \\
\text { snowfa11 } \\
\text { (in) } \\
\text { Sn }\end{array}$ & $\begin{array}{c}\text { Base-flow } \\
\text { index } \\
\left(\mathrm{ft}^{3} / \mathrm{s}\right) / \mathrm{mi}^{2} \\
\mathrm{Bf}\end{array}$ & $\begin{array}{c}\text { Hydraulic } \\
\text { conductivity } \\
(\mathrm{gal} / \mathrm{d}) / \mathrm{ft}^{2} \\
\mathrm{~K}\end{array}$ & $\begin{array}{l}\begin{array}{c}\text { Drift } \\
\text { thickness }\end{array} \\
(\mathrm{ft}) \\
\mathrm{H}\end{array}$ & $\begin{array}{c}\text { Transmissivity } \\
(\mathrm{gal} / \mathrm{d}) / \mathrm{ft} \\
\mathrm{T}\end{array}$ \\
\hline 30.5 & 0.63 & 40.0 & 0.36 & & & \\
\hline 30.7 & .50 & 41.0 & .32 & & & \\
\hline 31.0 & 2.21 & 45.7 & .34 & & & \\
\hline 31.0 & 1.65 & 44.2 & .20 & & & \\
\hline 33.5 & 1.47 & 53.6 & .00 & 74.6 & 47.3 & 3,530 \\
\hline 33.2 & .63 & 53.5 & .014 & 187 & 35.2 & 6,580 \\
\hline 33.0 & .12 & 47.0 & .028 & 10 & 35.0 & 350 \\
\hline 32.0 & .12 & 50.0 & .032 & 10 & 25.5 & 255 \\
\hline 31.0 & .06 & 45.3 & .00 & 10 & 25.7 & 257 \\
\hline 32.7 & 1.64 & 47.1 & .00 & 29.3 & 25.0 & 732 \\
\hline 31.1 & 7.02 & 47.4 & .17 & & & \\
\hline 31.0 & 2.58 & 42.4 & .56 & & & \\
\hline 31.1 & 1.47 & 41.0 & .28 & & & \\
\hline 31.0 & 1.76 & 48.6 & .15 & & & \\
\hline 31.0 & 1.65 & 50.0 & .29 & & & \\
\hline 31.0 & 1.65 & 48.9 & .45 & & & \\
\hline 31.7 & 1.39 & 46.0 & .36 & & & \\
\hline 31.8 & .50 & 47.0 & .38 & & & \\
\hline 31.8 & .42 & 46.0 & .34 & & & \\
\hline 31.9 & .51 & 45.0 & .40 & & & \\
\hline 32.4 & .50 & 45 & .30 & & & \\
\hline 33.0 & .50 & 43.5 & .26 & & & \\
\hline 33.1 & .50 & 40.3 & .39 & & & \\
\hline
\end{tabular}




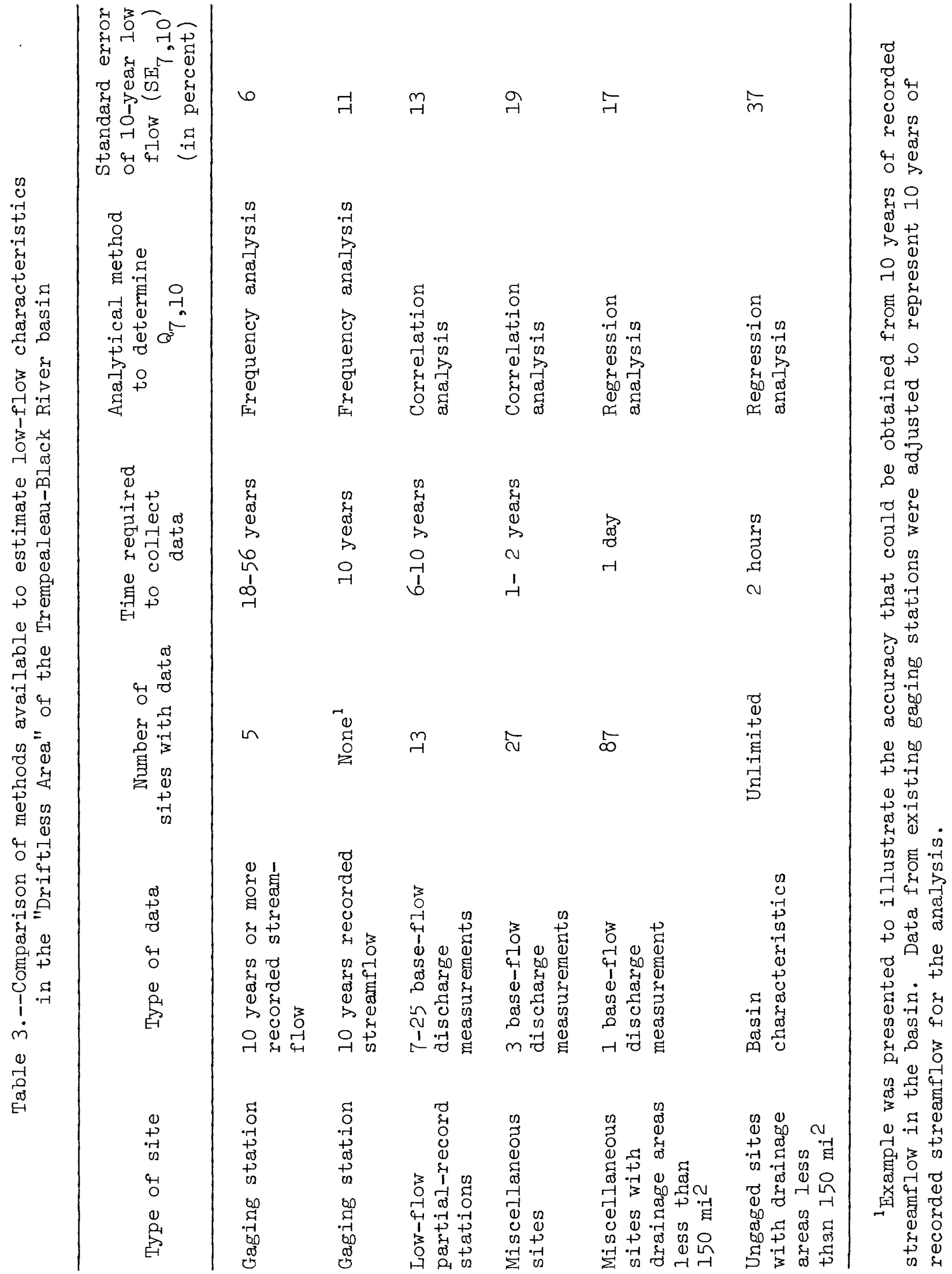




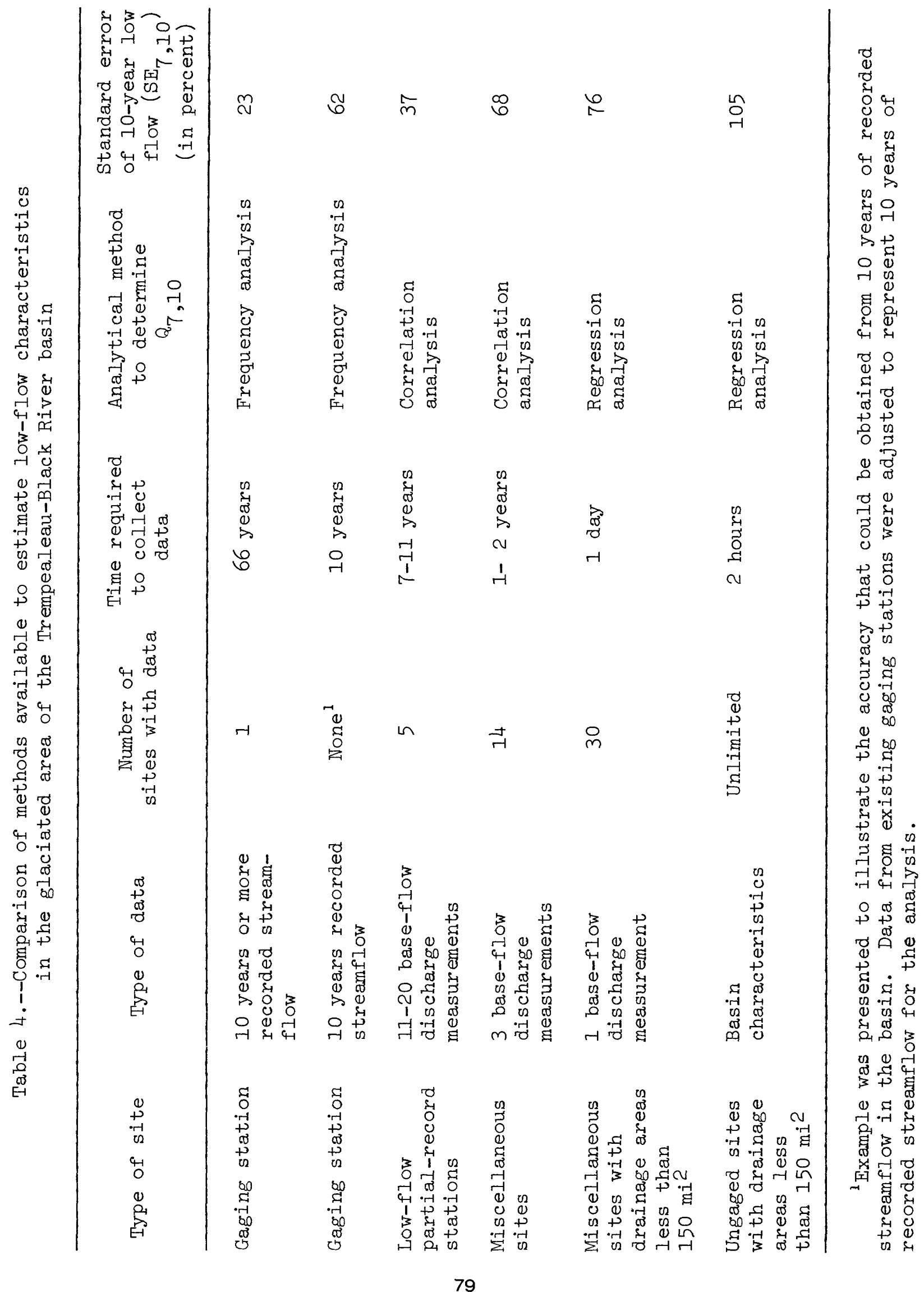

